\title{
The Path to Convertibility and Growth The Tunisian Experience
}

\author{
Saleh M. Nsouli, Sena Eken, Paul Duran,
} Gerwin Bell, and Zühtü Yücelik

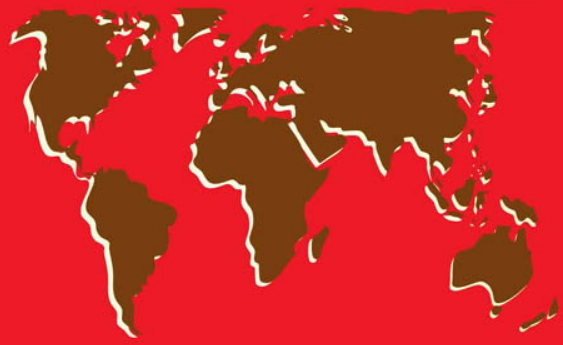


The Path to Convertibility and Growth

Saleh M. Nsouli, Sena Eken, Paul Duran, Gerwin Bell, and Zühtü Yücelik 
(c) 1993 International Monetary Fund

\section{Library of Congress Cataloging-in-Publication Data}

The Path to convertibility and growth : the Tunisian experience/ Saleh M. Nsouli ... [et al.].

p. $\mathrm{cm}$. - (Occasional paper : 109)

Includes bibliographical references.

ISBN 1-55775-357-1

1. Tunisia-Economic policy. 2. Structural adjustment (Economic policy)-Tunisia. 3. Currency convertibility-Tunisia. 4. Economic stabilization-Tunisia. I. Nsouli, Saleh M. II. Series:

Occasional paper (International Monetary Fund) ; no. 109.

HC820.p37 1993

$338.9611-\mathrm{dc} 20$

Price: US $\$ 15.00$

(US\$12.00 to full-time faculty members and students at universities and colleges)

Please send orders to: International Monetary Fund, Publication Services 700 19th Street, N.W., Washington, D.C. 20431, U.S.A.

Tel.: (202) 623-7430 Telefax: (202) 623-7201

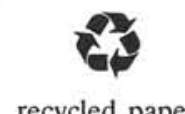

recycled paper 


\section{Contents}

Page

Preface vii

I. Introduction I

Box. Prereform Conditions in Tunisia 1

II. Economic and Financial Developments During 1970-86 3

III. Fiscal Policy and Reforms 5

Tax System 5

\begin{tabular}{ll}
\hline Tax Reforms & 8 \\
\hline
\end{tabular}

Expenditure Issues and Policies 9

\begin{tabular}{ll}
\hline Fiscal Outcome & 10 \\
\hline Social Issues and Protection & 12
\end{tabular}

\begin{tabular}{ll}
\hline Social Issues and Protection & 12 \\
\hline Outstanding Issues & 12 \\
\hline
\end{tabular}

IV. Monetary Policy and Financial Sector Reforms 14

Monetary Policy 15

\begin{tabular}{ll} 
Policy Instruments & 15 \\
\hline
\end{tabular}

\begin{tabular}{ll}
\hline Monetary Developments & 16 \\
\hline
\end{tabular}

\begin{tabular}{ll} 
Financial Sector Reforms & 17 \\
\hline
\end{tabular}

The Development of Financial Markets 19

\begin{tabular}{lr}
\hline Bank Restructuring and Reforms & 19 \\
\hline
\end{tabular}

\begin{tabular}{ll}
\hline Impact of the Reforms & 20 \\
\hline
\end{tabular}

\begin{tabular}{lr}
\hline Agenda for the Future & 21 \\
\hline
\end{tabular}

V. Structural Reforms $\quad 23$

\begin{tabular}{ll} 
Objectives and Strategy & 23 \\
\hline
\end{tabular}

Price Liberalization $\quad 23$

\begin{tabular}{ll}
\hline Public Enterprise Reform & 25 \\
\hline
\end{tabular}

\begin{tabular}{ll}
\hline Liberalization of Investment and Rationalization of Incentives & 26 \\
\hline
\end{tabular}

\begin{tabular}{ll}
\hline Trade Liberalization & 26 \\
\hline
\end{tabular}

\begin{tabular}{lc}
\hline Convertibility & 28 \\
\hline
\end{tabular}

\begin{tabular}{lr} 
VI. Performance & $\mathbf{3 0}$ \\
\hline
\end{tabular}

\begin{tabular}{ll} 
Growth and Its Sources & 30 \\
\hline
\end{tabular}

Investment and Savings 34

Inflation 36

\begin{tabular}{ll}
\hline Balance of Payments & 37 \\
\hline
\end{tabular}

External Debt $\quad 41$

VII. The Challenges and the Lessons $\quad 42$ 


\section{Charts}

\section{Section}

\begin{tabular}{lrr} 
III. 1. Fiscal Indicators & 8 \\
\hline IV. 2. Interest Rates, January 1988-March 1993 & 16 \\
\hline
\end{tabular}

\begin{tabular}{lll}
\hline IV. 2. Interest Rates, January 1988-March 1993 & 17 \\
\hline 3. Monetary Performance & 17
\end{tabular}

4. Evolution of Financial Instruments,

November 1989-March $1993 \quad 19$

\begin{tabular}{lr}
\hline 5. Indicators of Financial Intermediation and Deepening & 20 \\
\hline
\end{tabular}

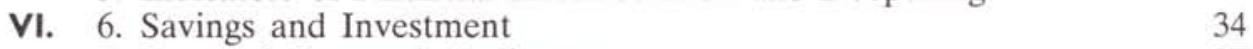

\begin{tabular}{ll} 
7. External Economic Indicators & 37 \\
\hline 8. Trade Performance & 38
\end{tabular}

\begin{tabular}{lr}
\hline 9. Composition of Exports & 41 \\
\hline
\end{tabular}

\section{Text Tables}

\section{Section}

III. 1. Selected Indicators of Fiscal Performance 6

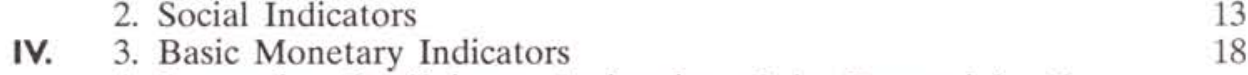

iv. 3. Regression Coefficients-Estimation of the Demand for Key

Financial Instruments

\begin{tabular}{lll} 
& & \\
vi. & Sectoral Distribution of Real GDP Growth & 31 \\
\hline
\end{tabular}

6. Sectoral Contribution to Real GDP Growth 32

\begin{tabular}{ll}
\hline 7. Value Added of Major Economic Sectors & 33 \\
\hline
\end{tabular}

\begin{tabular}{ll}
\hline 8. Savings-Investment Balance & 35 \\
\hline
\end{tabular}

\begin{tabular}{ll}
\hline 9. Price Developments & 36 \\
\hline
\end{tabular}

10. External Sector Indicators 39

11. Contribution of Changes in Trade Volume and Terms of
Trade to Changes in the Trade Balance

\section{Appendix I. Statistical Tables}

A1. Sectoral Distribution of Real GDP Growth

A2. Supply and Use of Resources-Real Growth Rates 44

\begin{tabular}{ll}
\hline A3. Sectoral Distribution of GDP & 45 \\
\hline .
\end{tabular}

\begin{tabular}{ll}
\hline A4. Supply and Use of Resources & 46 \\
\hline
\end{tabular}

\begin{tabular}{ll}
\hline A5. Production of Major Agricultural Crops & 47 \\
\hline
\end{tabular}

\begin{tabular}{ll}
\hline A6. Supply and Use of Cereals & 47 \\
\hline
\end{tabular}

\begin{tabular}{ll}
\hline A7. Producer Prices of Principal Agricultural Commodities & 48 \\
\hline
\end{tabular}

\begin{tabular}{ll}
\hline A8. Energy Production and Consumption & 48 \\
\hline
\end{tabular}

\begin{tabular}{lr}
\hline A9. Indicators of Tourist Activity & 49 \\
\hline
\end{tabular}

\begin{tabular}{ll} 
A10. Consumer Price Index & 49 \\
\hline
\end{tabular}

\begin{tabular}{lr}
\hline A11. Consumer Price Index by Price Regime & 50 \\
\hline
\end{tabular}

\begin{tabular}{lr}
\hline A12. Producer Price Index & 50 \\
\hline A13.
\end{tabular}

\begin{tabular}{lr}
\hline A13. Wage and Employment Indicators & 51 \\
\hline
\end{tabular}

A14. Gross Fixed Investment by Economic Sector and Financing

A15. Consolidated Financial Operations of the Central Government

A16. Consolidated Revenue and Grants of the Central

\begin{tabular}{lr} 
Government & 53 \\
\hline
\end{tabular}

\begin{tabular}{lc}
\hline A17. Government Petroleum Revenues & 53 \\
\hline
\end{tabular}

A18. Economic Classification of Consolidated Expenditure of the Central Government

A19. Operations of the Subsidy Fund

A20. Monetary Survey

A21. Assets and Liabilities of the Central Bank

\section{CInternational Monetary Fund. Not for Redistribution}


A22. Assets and Liabilities of Deposit Money Banks 57

\begin{tabular}{ll}
\hline A23. Selected Interest Rates & 58
\end{tabular}

\begin{tabular}{lr}
\hline A24. Balance of Payments & 59 \\
\hline
\end{tabular}

\begin{tabular}{lr}
\hline A25. Foreign Trade Indicators & 60 \\
\hline
\end{tabular}

A26. Value of Foreign Trade by Commodity Class 60

\begin{tabular}{ll}
\hline A27. Volume of Foreign Trade by Commodity Class & 61 \\
\hline
\end{tabular}

A28. Trade Balance in Hydrocarbons 62

A29. Exports of Phosphate Rock, Phosphate Derivatives, and

Other Chemical Products

A30. Exports and Imports of Primary Products by Major

Category

A31. Direction of Trade

64

A32. External Debt and Debt-Service Payments 66

\begin{tabular}{ll}
\hline A33. Composition of External Debt by Creditor & 67 \\
\hline
\end{tabular}

A34. Selected Exchange Rate Indices $\quad 68$

\begin{tabular}{lr}
\hline A35. Structure of Imports by Regime & 69 \\
\hline
\end{tabular}

Appendix II. Summary of the Tax System

References

The following symbols have been used throughout this paper:

... to indicate that data are not available;

- to indicate that the figure is zero or less than half the final digit shown, or that the item does not exist;

- between years or months (e.g., 1991-92 or January-June) to indicate the years or months covered, including the beginning and ending years or months;

/ between years (e.g., 1991/92) to indicate a crop or fiscal (financial) year.

"Billion" means a thousand million.

Minor discrepancies between constituent figures and totals are due to rounding.

The term "country," as used in this paper, does not in all cases refer to a territorial entity that is a state as understood by international law and practice; the term also covers some territorial entities that are not states, but for which statistical data are maintained and provided internationally on a separate and independent basis. 
This page intentionally left blank 


\section{Preface}

This paper was originally prepared for discussion in the IMF Executive Board. The authors are grateful to the Tunisian authorities for extensive background discussions and for their assistance in providing the requisite data. The authors wish to express their appreciation to Janet Bungay of the African Department for editing the original manuscript and Elisa Diehl of the External Relations Department for editing the final paper and coordinating its production. They would also like to thank Ilse-Marie Fayad for valuable research assistance, Marie-Thérèse Culp for her unstinting efforts in producing numerous drafts of the manuscript, and Alicia Etchebarne-Bourdin and the IMF Graphics Section for composition and artwork. The views expressed are the sole responsibility of the authors and do not necessarily reflect those of the IMF staff or IMF Executive Board. 
This page intentionally left blank 


\section{Introduction}

$\mathbf{T}$ unisia's adjustment experience during 1986-92 provides useful insights into the structural and macroeconomic policies that enabled the authorities to re-establish financial balances while transforming the economy, in a relatively short time, from an inward-looking and heavily regulated one into a predominantly market- and export-oriented one.

After achieving independence in 1956, Tunisia embarked on a strategy involving pervasive government control of the incentive structure and production through widespread regulations and the establishment of an important public enterprise sector, and through successive development plans, under which the Government invested heavily. Concurrently, emphasis was given to the development of human capital and the provision of basic health services, while an important social security system was put in place. In the late 1960s, Tunisia shifted its policy strategy to encourage the development of the private sector by protecting it against external competition while continuing to apply extensive controls. Although Tunisia has relatively modest petroleum deposits, the surge in international petroleum prices in the early 1970 s enabled the Government to expand its investment levels sharply and to grant high wage adjustments. The combination of these policies contributed to significant economic distortions and rigidities.

With the fall in international petroleum prices and the dwindling of petroleum reserves in the early 1980 s, Tunisia's external sector position started to deteriorate. Although the Government began to cut back on public investment and to slow down wage increases, these measures were insufficient to tackle Tunisia's deep-rooted structural problems. Thus, despite an intensification of trade and exchange controls, by mid-1986 Tunisia's gross international reserves had fallen precipitously, to the equivalent of a few days of imports. Unemployment had also risen to an estimated 15 percent, with indications that, unless there was a major shift in policy stance, it was likely to continue climbing rapidly.

The Tunisian Government reassessed its policy strategy, recognizing that the economy was saddled with heavy distortions and controls that limited productivity, encouraged inefficient import substitution, and discouraged financial savings, and with a large absorption of resources by the public sector that directly hindered the contribution of the private sector to growth and employment creation (see box).

\section{Prereform Conditions in Tunisia}

- A large budgetary deficit, which averaged 5.2 percent of GDP during 1981-86, with average expenditure reaching 40 percent of GDP by $1985-$ 86 and non-oil revenue, about 30 percent.

- An expansionary monetary policy, fueled in part by the financing requirements of the budget and public enterprises, as well as negative real interest rates, which contributed not only to the demand for credit but also to distortions in credit allocation and a weakening in the soundness of the banking system.

- A large and inefficient public enterprise sector, which relied heavily on government support and bank financing.

- A widespread system of price, investment, trade, credit, and exchange controls that substantially distorted both consumption and investment decisions.

- The widening of the external current account deficit, which rose from about 5 percent of GDP in 1980 to a peak of some 11 percent in 1984 and averaged close to 8 percent of GDP in 1985-86, reflecting the high level of aggregate demand, a slowdown in export performance, and an increasingly overvalued currency in the face of deteriorating terms of trade.

- A rising level of external debt, which increased from 38 percent of GDP in 1981 to 63 percent in 1986, and a doubling of the debtservice ratio, which moved from 14 percent of current receipts in 1981 to 28 percent in 1986. 
Against the background of these problems, the Government embarked in August 1986 on a twopronged adjustment strategy aimed at

- improving resource allocation by dismantling the price, investment, trade, and exchange controls in effect and adjusting the exchange rate to a realistic level; and

- reducing government absorption of resources and improving monetary management, thereby releasing resources to the private sector while restraining the growth in aggregate demand.

This strategy called for comprehensive structural and macroeconomic reform measures, coupled with a prudent external debt policy designed to alleviate the rising debt-service burden. The Government made significant strides in liberalizing the economy and re-establishing domestic and external financial balances, supported, starting in 1986, by a stand-by arrangement from the IMF, and, subsequently, by a four-year extended arrangement. Meanwhile, the World Bank provided support, initially in 1986 in the form of an agricultural sector adjustment loan, followed by an industrial and trade policy adjustment loan in 1987, two structural adjustment loans (in 1988 and 1991), a second agricultural sector adjustment loan in 1989, and a public enterprise reform loan in 1989. Tunisia did not seek debt rescheduling and, throughout this period, serviced its external debt on schedule.

The key economic and financial developments in Tunisia from the beginning of the 1970s through the mid-1980s show how the Government's policies contributed to the emergence of serious imbalances that threatened the further expansion of economic activity, price stability, and the viability of the balance of payments (Chapter II).

During 1987-92 the Government attempted to redress the fiscal position and reduce government absorption through a combination of tax reforms, involving primarily the introduction of a valueadded tax (VAT) and the reform of the income tax system, and a restrained expenditure policy, involving cuts in current and capital expenditure as a ratio to GDP. The Government encountered difficulties in reducing the overall budget deficit, which did not narrow substantially until 1992, even though fiscal policy was adapted promptly to mitigate the impact of exogenous factors. Under the reform program, the introduction of marketoriented treasury debt instruments changed the nature of deficit financing from net foreign financing and net domestic bank financing to nonbank financing. Chapter III focuses on these reform efforts and subsequent developments.

Chapter IV outlines the reforms undertaken to improve monetary management, foster the development of financial markets, and strengthen the banking system. It explains how the monetary authorities conducted monetary policy in line with the objective of supporting the growth of the private sector while reducing financial imbalances. It analyzes how the reforms helped to improve financial intermediation and foster financial deepening and shows how the development of financial instruments affected monetary programming.

Chapter V reviews the progress made in structural reforms that were instrumental in Tunisia's transformation. It traces the actions taken over time to dismantle the pervasive price controls. It examines the Government's efforts starting in 1989 to restructure, liquidate, and privatize various public enterprises by granting them greater autonomy, elaborating performance contracts for selected enterprises, and initiating the first phase of privatization of small and medium-size enterprises.

It also shows how the legal framework and tax reforms were designed to encourage private investors by reducing the barriers to entry into the market and tackling the tax distortions, and points to the work under way to further harmonize incentives through the introduction of a unified investment code that provides more uniform treatment across sectors than did the sectoral investment codes. In addition, this chapter traces the process of reducing quantitative trade restrictions as well as lowering and rationalizing import tariffs. Finally, the chapter describes the steps that Tunisia took, in the context of its outward-looking strategy, to phase out foreign exchange controls, thereby establishing currency convertibility for current account transactions by January 1993, and currency convertibility for capital account transactions for nonresidents.

The policies Tunisia pursued contributed to (1) a broadly based acceleration in economic activity, with real growth nearly doubling during 1987-92 from its rate in 1982-86; (2) a rise in gross fixed investment as a ratio of GDP starting in 1989 , spurred by a sharp increase in private sector investment made possible by a sizable improvement in the savings performance of the non-Central Government; (3) a substantial reduction in inflationary pressures; (4) a strengthening of the external sector position, with export growth and diversification benefiting partly from a strong real effective depreciation of the dinar in 1986-87; and (5) a reduction in the external debt and debt-service ratios. Chapter VI documents these events.

The last chapter highlights some of the major challenges facing the Tunisian economy in the years ahead and draws some lessons from Tunisia's adjustment experience that can be useful for other countries embarking on macroeconomic adjustment and structural reforms. 


\section{Economic and Financial Developments During 1970-86}

\section{T} he Tunisian economy grew rapidly during $1970-80$, averaging an annual growth rate of 7.4 percent, while domestic financial stability and a strong balance of payments position were maintained. Economic growth was broadly based, with a particularly strong performance in the manufacturing sector, which achieved an average annual increase in real value added of 11.0 percent, thereby increasing its share in GDP from 8.4 percent in 1970 to 11.9 percent in 1980 . The growth of the economy reflected the high and rising levels of investment, which increased from 20 percent of GDP in 1970 to 29 percent in 1980. A large share of public investment was directed toward the development of human resources and infrastructure. While consumption in real terms grew at an average annual rate of 9 percent, national savings rose in line with investment, as petroleum revenues increased rapidly because of favorable world prices and generally restrained financial policies.

Thus, although government expenditure in percent of GDP exhibited a rising trend during this period, the overall budget deficit was held to the equivalent of less than 2 percent of GDP on average, except in 1976-78, when revenue was adversely affected by declining world market prices of oil and phosphates, two of Tunisia's biggest exports. Demand-management policies, the sharp improvement in the terms of trade, and the depreciation of the dinar in real effective terms enabled the Government to maintain the external current account deficit at about 6 percent on average during 1970 80 , with the average reaching about 9 percent only during 1976-78. Most of the financing was provided by official sources, largely on concessional terms, and by direct foreign investment. As a result, the debt-service ratio rose from 10 percent in 1970 to only 12 percent in 1980, while outstanding debt increased from 32 percent of GDP in 1976 to 36 percent in 1980.

Tunisia's rapid economic development was accompanied by an increasing role for the Government, as evinced by the following:

- the rising share of government expenditure in GDP;
- the expansion of the public enterprise sector, which came to dominate various sectors of economic activity;

- a pervasive system of controls, which influenced resource allocation;

- various incentives created to guide private sector investment to particular sectors;

- comprehensive, quantitative import restrictions and protection resulting from high and widely dispersed import tariffs;

- price controls designed to protect consumers in view of the limited competition in the domestic market;

- the establishment of an elaborate social security system; and

- the introduction of subsidies.

Tunisia's economic and financial situation deteriorated markedly in 1981 as a result of declining petroleum production, a deceleration in mining and manufacturing output, and the effects of recurrent bad weather on the agricultural and agroindustrial sectors. In 1981-86, economic activity slowed down, with real GDP averaging a growth rate of 3.3 percent a year. At the same time, domestic and external imbalances increased significantly owing to the expansionary financial policies and the decline in Tunisia's terms of trade, linked principally to world petroleum prices. In response to these pressures, the Government relied even more on price controls and tightened import restrictions and investment controls, which resulted in a growing rigidity of the economic system and increasingly severe distortions.

In 1981-84, domestic demand was allowed to expand faster than GDP. Although the expansion in 1981 stemmed from a further rise in investment, the acceleration in 1982-84 was fully attributable to increased consumption, which was fueled by the large rise in the wage bill in the economy and the substantial transfer payments by the Government to enterprises and households. As a result, gross domestic savings declined from 24.0 percent of 
GDP in 1980 to 20.3 percent in 1984 , and the resource gap widened from 5.4 percent of GDP to 11.7 percent. After the Government tightened investment controls and scaled down capital spending in 1985, the resource gap narrowed sharply, to 6.1 percent of GDP.

Between 1980 and 1983-84, the overall budget deficit more than doubled as a percentage of GDP, to 6.7 percent on average, before narrowing significantly, to 3.7 percent of GDP in 1985 . Although revenue rose substantially, budget expenditure accelerated between 1980 and 1984 mainly on account of subsidies, current transfers, and net lending. Apart from increases in consumer subsidies and benefits under the social security system, the growth of current transfers and net lending largely mirrored the increase in operating losses of public enterprises. The sharp rise in net lending by the Government not only resulted in a deterioration of the Government's financial position but also allowed the nongovernment sector, including public enterprises, to widen its savings-investment gap substantially. The sharp reduction in the budget deficit in 1985 can be fully explained by the contraction in government net lending that accompanied the tightening of investment controls on public enterprises.

The effects of the expansionary fiscal policies in 1981-85 were reinforced by a highly accommodating monetary policy stance. Credit expanded at a compound rate of some 20 percent a year, with credit to the Government and the economy rising at virtually the same rate over the period as a whole. The annual growth rate of broad money was equivalent to a compound rate of 16.4 percent, exceeding the expansion of nominal GDP in all but one year by an average of some 3 percentage points.

On the external side, the current account deficit more than doubled as a percentage of GDP between 1980 and 1984, when it reached 10.9 percent. This increase was caused primarily by the downward trend of exports, owing in particular to the reduction in exports of petroleum products and phosphates, associated largely with the decline in world market prices, the decline in the receipts from tourism and workers' remittances, and the increase in interest payments on the external public debt. The Government was able to reduce the current account deficit to 7.1 percent of GDP in 1985 by tightening investment controls and import restrictions, which caused a sharp drop in imports, as well as by cutting back capital outlays. The successive, sizable deficits and the ever-greater recourse to international financial markets to finance them led to a serious deterioration in the external debt indicators, with the debt-service ratio rising to 21.6 percent and the debt-to-GDP ratio increasing to 46 percent by 1985 . In addition, gross official international reserves declined to the equivalent of only one month of imports by the end of 1985, compared with two months in 1980.

In late 1985, the Government adopted measures aimed at containing the deficit and, concurrently, initiated the liberalization of domestic prices, imports, and investment with a view to improving the efficiency of resource use. However, despite these steps, the liberalization of the economy was delayed, and Tunisia's situation worsened because of a further sharp deterioration in the terms of trade, a severe drop in domestic cereal production resulting from unfavorable weather conditions, and reduced receipts from tourism owing to increased regional tensions.

Faced with financial imbalances that had become unsustainable, the Government decided in late 1986 to adopt a comprehensive adjustment program aimed at laying the foundation for a sustained improvement in economic growth and reestablishing financial balances over the medium term. The program called for the adoption of tight demand-management policies and a significant improvement in economic competitiveness. At the same time, it included comprehensive structural adjustment measures that reoriented economic policies away from heavy reliance on administrative controls and that decreased public sector involvement by increasing the role of market signals and the private sector. 


\section{Fiscal Policy and Reforms}

\begin{abstract}
A $\mathrm{t}$ the beginning of the $1980 \mathrm{~s}$, the decline in oil production, coupled with the fall in oil prices in world markets, substantially reduced the resources available to the Tunisian public sector. Even though tax revenue mobilization efforts were stepped up, the growth in government consumption and investment was so high that the budgetary position of the Central Government deteriorated (Table 1 and Chart 1). As a result, domestic and external debt accumulated substantially during the first half of the 1980 s. The fiscal imbalances contributed to reducing the resources available to the private sector and exerting pressure on the external sector position.

The strategy adopted by the authorities in late 1986 required a sustained fiscal adjustment so as to release resources to the private sector, improve the distribution of the tax burden, reduce tax distortions, ameliorate the savings performance of the government sector, reduce the weight of the Government in the economy, and ease the external debt burden. In line with this strategy, the fiscal policies under the adjustment programs focused on reforming the tax system and reducing government expenditure in relation to GDP while simultaneously protecting the poorest segments of the population and increasing the efficiency of government investment.
\end{abstract}

\section{Tax System}

Until the mid-1980s, Tunisia's tax system was economically distortionary, often inequitable, complicated, and difficult to administer. The direct income tax system was schedular, containing a large number of taxes whose scope and rates differed by type of income or sector of activity. The main taxes were levied on profits from commercial activities, profits from professional activities, wages, dividends, and interest income. A solidarity tax was attached to these taxes. In addition to the schedular taxes, a general income tax, with marginal rates ranging from 10 percent to 80 percent, was levied on the total personal income of all income earners.
Indirect taxes consisted of three turnover taxes - on production, consumption, and servicestogether with a series of excise taxes. The production tax and the consumption tax were levied on domestically produced and imported goods, while the tax on services applied to commercial services other than the sale of goods, including professional services. Many transactions were subject to both production and consumption taxes, which resulted in 16 different effective tax rates ranging from 6.4 percent to 45.9 percent. For each category of turnover tax, different exemption and deduction rules applied. Tax credits were granted for inputs, including equipment and buildings. In general, there was no deductibility among the three taxes, with two exceptions: the tax on services was deducted for producers who were subject to the production tax, and the consumption tax on alcohol could be deducted from the production tax on hotel operations.

In addition, customs duties were applied to imports to protect the local industry from foreign competition and to contain the demand for imports of consumer goods. These duties ranged from 5 percent to 236 percent, but imports of raw materials and semifinished goods used by local industry to produce exported goods were exempted. Import duties constituted an important source of revenue, accounting for close to two fifths of total tax revenue. Thus, the budgetary outcome was very much influenced by the changes in the level and the composition of imports from one year to another.

Finally, revenue earmarking distorted budget unity and complicated fiscal management. During $1982-86$, only 76 percent of central government revenue was recorded in the budget. The rest was earmarked for extrabudgetary operations, involving 40 Special Treasury Accounts and investment and participation funds (fonds de concours).These operations were also financed directly through external grants and loans. They covered both current outlays and investment projects that remained outside budgetary control procedures and were equivalent to some 37 percent of total government expenditure during the same period. 
Table I. Selected Indicators of Fiscal Performance

\begin{tabular}{|c|c|c|c|c|c|c|c|c|c|c|c|c|}
\hline & 1981 & 1982 & 1983 & 1984 & 1985 & 1986 & 1987 & 1988 & 1989 & 1990 & 1991 & 1992 \\
\hline & \multicolumn{12}{|c|}{ (In percent of GDP) } \\
\hline Total revenue & 31.9 & 34.3 & 33.7 & 36.5 & 35.4 & 34.6 & 31.7 & 31.2 & 30.4 & 29.9 & 28.7 & 28.9 \\
\hline Tax revenue & 23.9 & 25.9 & 26.9 & 26.5 & 26.5 & 26.7 & 23.7 & 23.1 & 23.4 & 23.2 & 23.6 & 23.7 \\
\hline Taxes on income and profits & 4.9 & 5.1 & 4.6 & 4.5 & 4.5 & 4.8 & 4.2 & 3.7 & 3.9 & 4.6 & 4.1 & 4.0 \\
\hline Taxes on goods and services & 7.4 & 7.2 & 7.4 & 7.2 & 7.2 & 8.0 & 7.2 & 6.7 & 6.3 & 7.6 & 6.8 & 6.8 \\
\hline Taxes on foreign trade & 7.9 & 9.4 & 10.6 & 10.4 & 9.5 & 8.6 & 7.9 & 8.4 & 9.2 & 8.7 & 7.8 & 8.0 \\
\hline Other taxes & 3.7 & 4.3 & 4.3 & 4.4 & 5.3 & 5.3 & 4.4 & 4.3 & 4.0 & 2.3 & 4.9 & 4.9 \\
\hline Nontax revenue & 8.1 & 8.4 & 6.8 & 10.0 & 8.9 & 7.8 & 8.0 & 8.1 & 7.0 & 6.6 & 5.1 & 5.2 \\
\hline Petroleum sector & 5.4 & 6.9 & 4.9 & 5.6 & 5.5 & 4.5 & 4.4 & 4.5 & 4.1 & 2.3 & 2.1 & 2.1 \\
\hline Other & 2.7 & 1.5 & 1.9 & 4.4 & 3.4 & 3.3 & 3.6 & 3.6 & 2.9 & 4.3 & 3.0 & 3.1 \\
\hline Total expenditure and lending & 34.6 & 39.9 & 42.0 & 42.5 & 40.0 & 39.2 & 36.0 & 36.0 & 36.1 & 34.5 & 34.3 & 31.9 \\
\hline Current expenditure & 21.9 & 26.8 & 28.7 & 28.2 & 27.7 & 26.7 & 26.1 & 26.0 & 27.9 & 26.1 & 26.0 & 25.1 \\
\hline Wage bill & 9.9 & 10.0 & 10.4 & 10.2 & 10.0 & 10.6 & 9.7 & 9.6 & 9.8 & 9.2 & 9.5 & 9.3 \\
\hline Goods and services & 3.2 & 4.2 & 5.6 & 3.7 & 3.1 & 2.6 & 2.7 & 1.9 & 2.1 & 2.1 & 2.3 & 2.1 \\
\hline Interest payments & 1.6 & 2.0 & 2.4 & 2.7 & 2.8 & 3.2 & 3.1 & 3.2 & 3.3 & 3.1 & 3.4 & 3.1 \\
\hline Subsidies and transfers & 7.2 & 10.6 & 10.3 & 11.6 & 11.8 & 10.4 & 10.6 & 11.3 & 12.6 & 11.6 & 10.8 & 10.5 \\
\hline Of which: Consumer subsidies & 3.4 & 3.3 & 3.1 & 4.1 & 3.4 & 3.0 & 2.3 & 2.7 & 3.6 & 2.7 & 2.2 & 1.8 \\
\hline Capital expenditure & 11.3 & 11.5 & 9.3 & 9.4 & 9.9 & 10.1 & 7.9 & 9.2 & 7.5 & 8.0 & 8.4 & 6.4 \\
\hline Direct investment & 6.1 & 6.8 & 4.5 & 5.1 & 4.6 & 5.6 & 4.0 & 5.2 & 4.2 & 4.5 & 5.7 & 4.0 \\
\hline Capital transfers & 5.2 & 4.7 & 4.8 & 4.3 & 5.3 & 4.5 & 3.9 & 4.0 & 3.3 & 3.5 & 2.7 & 2.4 \\
\hline Net lending & 1.4 & 1.6 & 4.0 & 4.9 & 2.4 & 2.4 & 2.0 & 0.8 & 0.7 & 0.3 & -0.1 & 0.5 \\
\hline Overall deficit including grants & -2.5 & -5.4 & -7.7 & -5.7 & -3.7 & -4.6 & -4.1 & -4.5 & -4.3 & -3.9 & -5.4 & -2.6 \\
\hline Overall deficit excluding grants & -2.7 & -5.6 & -7.9 & -5.8 & -3.8 & -4.6 & -4.3 & -4.8 & -5.7 & -4.6 & -5.6 & -3.0 \\
\hline Total financing & 2.5 & 5.4 & 7.7 & 5.7 & 3.7 & 4.6 & 4.1 & 4.5 & 4.3 & 3.9 & 5.4 & 2.6 \\
\hline Net foreign financing & 2.5 & 4.1 & 5.1 & 3.3 & 3.1 & 3.1 & 1.2 & 1.6 & 1.2 & 0.7 & 2.6 & 0.2 \\
\hline Net domestic financing & - & 1.3 & 2.6 & 2.4 & 0.6 & 1.5 & 2.9 & 2.9 & 3.1 & 3.2 & 2.8 & 2.4 \\
\hline
\end{tabular}


Tax revenue

Taxes on income and profits

Taxes on goods and services

Taxes on foreign trade

Other taxes

Nontax revenue

Petroleum sector

Other

\section{Current expenditure}

Wage bill

Goods and services

Interest and public debt

Subsidies and transfers

Capital expenditure

Direct investmen

Capital transfers

Foreign financing (net)

Domestic financing

Banks

Nonbank'

$\begin{array}{rrrr}74.7 & 75.5 & 79.9 & 72.6 \\ 15.3 & 14.7 & 13.6 & 12.2 \\ 23.4 & 20.9 & 22.0 & 19.8 \\ 24.8 & 27.3 & 31.4 & 28.4 \\ 11.2 & 12.6 & 12.9 & 12.2 \\ 25.3 & 24.5 & 20.1 & 27.4 \\ 17.0 & 20.0 & 14.7 & 15.3 \\ 8.3 & 4.5 & 4.4 & 12.1\end{array}$

70.0
26.1

11.0

5.2

$\begin{array}{rr}4.7 & 5.2 \\ 1.9 & 27.7\end{array}$

$\begin{array}{ll}21.9 & 27.7 \\ 34.1 & 30.0\end{array}$

$18.4 \quad 17.8$

$15.7 \quad 12.2$

75.3
27.4
14.8
5.7
27.5
24.7
11.8
12.9

75.0

27.0

9.9

6.7

31.4

25.0

13.6
11.4

$103.0 \quad 75.2$

75.2

24.8
19.6

19.6
5.1

$\begin{array}{ll}66.7 & 58.5 \\ 33.3 & 41.5 \\ 11.1 & 27.4 \\ 22.2 & 14.1\end{array}$

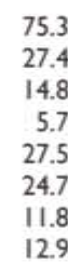

(In percent of total revenue)

$\begin{array}{rrrrrrrr}74.9 & 77.4 & 74.9 & 73.8 & 77.1 & 77.6 & 82.3 & 81.7 \\ 12.8 & 13.9 & 13.2 & 12.0 & 12.9 & 12.3 & 14.3 & 13.9 \\ 20.3 & 23.1 & 22.6 & 21.6 & 20.7 & 21.8 & 23.9 & 23.4 \\ 26.8 & 25.0 & 25.0 & 26.9 & 25.0 & 27.0 & 27.3 & 27.5 \\ 15.0 & 15.4 & 14.1 & 13.3 & 18.5 & 16.5 & 16.8 & 16.9 \\ 25.1 & 22.6 & 25.1 & 26.2 & 22.8 & 22.4 & 17.7 & 18.3 \\ 15.5 & 12.9 & 13.9 & 14.3 & 13.5 & 12.0 & 7.3 & 7.4 \\ 9.6 & 9.7 & 11.2 & 11.9 & 9.3 & 10.4 & 10.4 & 10.9\end{array}$

(In percent of total expenditure)

$\begin{array}{rrrrrrrr}73.7 & 72.6 & 76.7 & 73.8 & 78.8 & 76.5 & 75.6 & 79.7 \\ 26.6 & 28.8 & 28.7 & 27.3 & 27.8 & 27.1 & 27.6 & 29.7 \\ 8.3 & 7.1 & 7.8 & 5.4 & 6.1 & 6.2 & 6.8 & 6.6 \\ 7.5 & 8.6 & 9.0 & 9.1 & 9.2 & 9.1 & 9.9 & 10.0 \\ 31.3 & 28.1 & 31.2 & 32.0 & 35.7 & 34.1 & 31.3 & 33.4 \\ 26.3 & 27.4 & 23.3 & 26.2 & 21.2 & 23.5 & 24.4 & 20.3 \\ 12.1 & 15.2 & 11.8 & 14.7 & 11.8 & 13.3 & 16.6 & 12.8 \\ 14.2 & 12.2 & 11.5 & 11.5 & 9.4 & 10.2 & 7.8 & 7.5\end{array}$

(In percent of total financing)

$$
30.5 \quad 36
$$

$\begin{array}{llll}82.9 & 66.7 & 30.5 & 36.3 \\ 17.7 & 33.3 & 69.5 & 63.7\end{array}$

Source: Ministry of Finance.

IIncluding payment float, errors, and omissions. 
Chart I. Fiscal Indicators

(In percent of GDP)
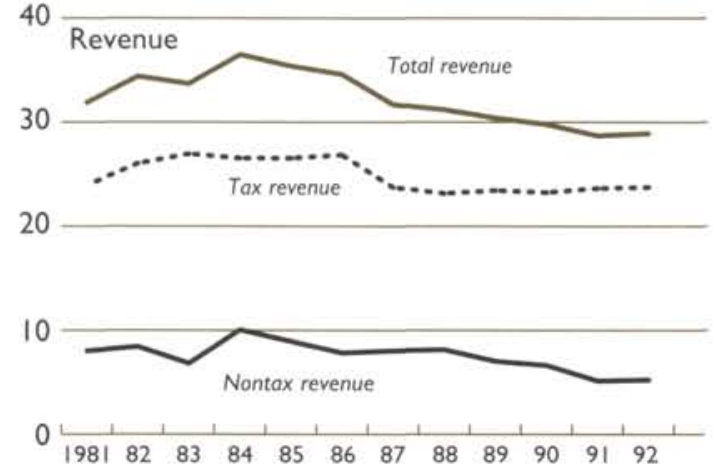

15

Fiscal Balance and Government Savings

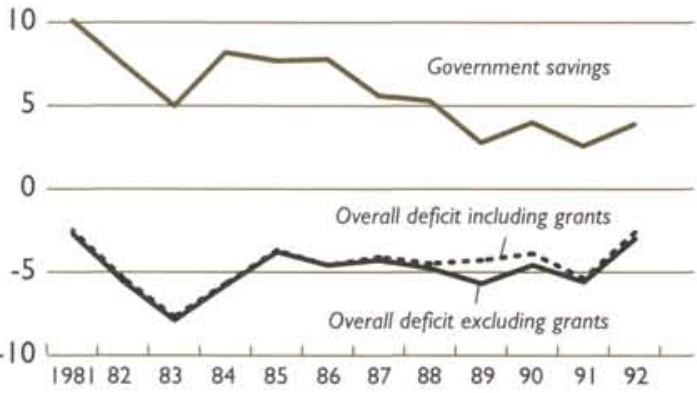

Source: Tunisian authorities.
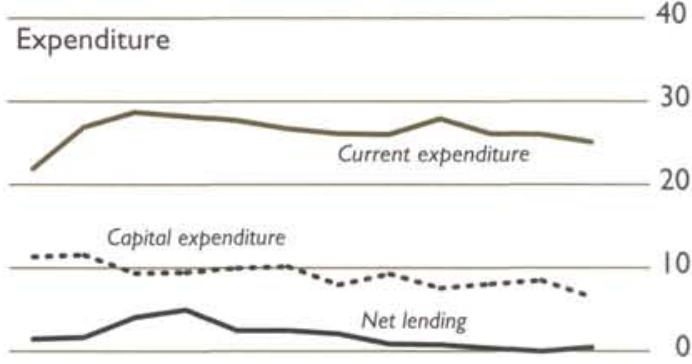

$\begin{array}{llllllllllll}1981 & 82 & 83 & 84 & 85 & 86 & 87 & 88 & 89 & 90 & 91 & 92\end{array}$

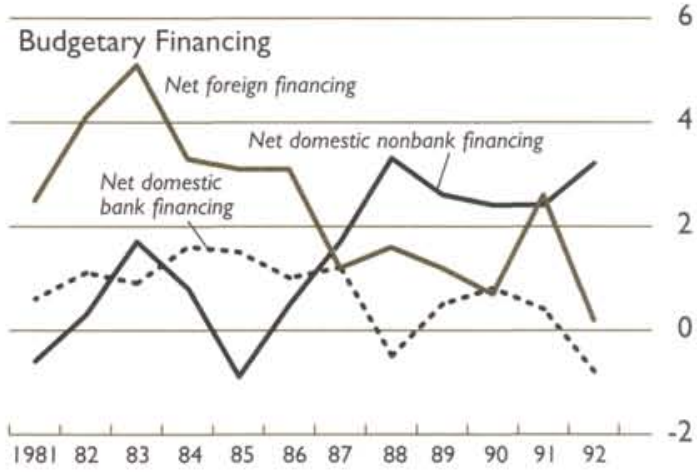

rates: (1) a general rate of 17 percent on most goods and services; (2) 6 percent on basic consumer goods and services; and (3) 29 percent on luxury goods. Under the new system, the VAT paid on all elements in the cost structure, including fixed capital, was in general fully deductible from the tax due on transactions in final goods and services. The distortions inherent in a system of cascading taxes, which were imposed at various stages of production, were thereby avoided. Because exports were not subject to the VAT, all taxes levied during the production process of export goods were eligible for full reimbursement. In October 1989, the VAT was extended to wholesale trade activities, except in the food sector.

The authorities embarked on a comprehensive, direct tax reform by introducing a new tax code, 
effective January 1990, that covered the taxation of personal and corporate profits. The existing schedular, general income, and solidarity taxes were abolished and replaced by a single personal income tax, and the existing corporate tax by a new corporate tax. Under the new personal income tax, the number of income brackets was reduced to 6 from 18 , and tax rates ranging from 15 percent to 35 percent were established. Under the new corporate tax, the six rates-differentiated according to economic sector, with a top rate of 44 percent-were replaced by two rates, a standard rate of 35 percent and a special rate of 10 percent applicable to cooperatives and to enterprises in the handicrafts, agriculture, and fishing sectors. At the same time, exemptions and deductions were reduced to expand the tax base, and tax withholding was extended to payments of interest, professional fees, and commissions and to rentals paid by public authorities and corporations. Finally, tax payments were shifted to a current basis to reflect the taxpayers' actual ability to pay.

To liberalize the Tunisian economy, the authorities gradually removed quantitative restrictions on imports and implemented a customs tariff reform with a view to rationalizing and reducing tariffs. Under the customs tariff reform, the maximum tariff was reduced to 43 percent from 236 percent, and the tariff dispersion was narrowed substantially. As a result, the average tariff rate fell from 36 percent in 1986 to 26 percent in 1992 . To simplify the existing system of duties so as to increase compliance, the authorities also elaborated a draft code for stamp and registration duties. It was adopted by the Parliament in May 1993.

In line with the objective of reducing the Government's role in the economy, the authorities did not introduce major new taxes. However, some revenue measures taken in the last half of the 1980s involved increases in tax rates on alcohol, tobacco, services, and petroleum. In addition, to mitigate the impact of the Middle East crisis on government finances, temporary surcharges on income taxes and import duties were introduced in March 1991. The surcharge on income taxes was subsequently eliminated at the beginning of 1992 , but that on import duties was extended until the end of 1993.

Meanwhile, the tax administration was strengthened significantly through improvements in tax assessment and collection procedures and the reinforcement of tax auditing procedures. The authorities granted a tax amnesty in late 1987, with a view to bringing potential taxpayers into the tax net and reducing tax evasion. Subsequently, the tax administration continued its efforts to enlarge the tax base by identifying potential taxpayers.

\section{Expenditure Issues and Policies}

The decline in oil revenue and the increased debtservice payments, in the absence of significant new or higher taxes, required a substantial reduction in the ratio of government expenditure to GDP in order to lower the budget deficit. Under the adjustment program, the Government envisaged significant reductions in expenditure and net lending, aimed at improving the efficiency of resource use, and planned to reduce its share in total investment.

Reducing current expenditure was difficult because of the rigidities in the system and the need to complement these cuts with other structural reforms. The major item in current expenditure was the wage bill. At the beginning of the program period, civil service wage rates had been frozen for two years at their 1984 level. Although the freeze continued during 1986-87, the wage bill rose owing to the wage drift built into the system and the increase in the size of the civil service. The increase in the civil service, primarily to meet the needs of the education and health sectors, was limited to an average growth rate of about 2 percent a year in 1986-88. After a four-year wage freeze, the authorities granted increases, equivalent to about 3 percent each, in productivity premiums in January and October 1988. At the beginning of 1989, they granted an increase in public sector salaries of about 5 percent, which reversed the declining trend in the ratio of the wage bill to GDP from 1986 onward.

In 1990, employers, employees, and the Government collaborated on a three-year wage policy aimed at avoiding annual confrontations between employers and employees while providing a framework in which productivity could be encouraged, competitiveness preserved, and real wages prevented from declining to levels that would erode incentives to work. The resulting guidelines that were agreed upon on July 1, 1990 provided for annual salary increases of about 5.6 percent in the public administration over the following three years. During this period, some seven thousand employees a year were recruited, representing increases of about 2-3 percent in the number of government employees.

At the beginning of 1986, the other major category of current expenditure was subsidies and transfers, which do not affect Tunisia's aggregate resource position but are reflected in the Government's savings performance. Budgetary expenditure under subsidies and transfers includes consumer subsidies, social security payments, transfers to hospitals and schools to cover their current outlays, and transfers to public enterprises to cover their operating losses. The authorities' policy aimed at gradually reducing the ratio of consumer subsidies to GDP. The gradual approach was 
intended to safeguard the benefits of the poorest segments of the population to the extent possible by raising prices initially on goods they were less likely to need. In addition, mechanisms were developed to target subsidies more effectively and to limit them to low-income groups.

The authorities also improved cost-recovery mechanisms to reduce transfers to public enterprises from the Government's budget, which included operating subsidies and financing of the enterprises' losses. However, they had difficulty because, to reduce these transfers significantly, they had to strengthen the financial position of the enterprises through comprehensive reforms that took time to formulate and implement.

Expenditure on goods and services had been substantially reduced in $1984-85$, with adverse effects on the operation and maintenance of public assets. Starting in 1986, more importance was given to maintenance programs to increase returns on existing capital and infrastructure as well as to reduce, over time, the need for replacement investment. In these circumstances, the authorities aimed at keeping expenditure on goods and services more or less constant in real terms under the adjustment program while increasing operation and maintenance outlays, especially for infrastructure.

Public investment averaged 56 percent of total gross fixed capital formation during Tunisia's Sixth Development Plan (1981-86), with public enterprises typically accounting for two thirds, and the Central Government for one third, of this total. In line with the overall objective of reducing the role of the public sector in the economy, the authorities' policy in the second half of the 1980s was to reduce the Government's direct and indirect share in investment and to increase its efficiency. The impact of the decline in public sector investment was expected to be offset by a pickup in private sector investment, while the budgetary position of the Central Government was expected to strengthen. Accordingly, the authorities canceled all outstanding but unused budgetary authorizations for capital expenditure at the beginning of 1987, thus allowing the Seventh Development Plan (1987-91) to be launched without a backlog of uncommitted but authorized expenditure.

During 1987-92, the growth of capital expenditure was limited to an average of about 5.2 percent a year, lower than the average annual increases in inflation of about 7.2 percent during the same period. In the meantime, the authorities, with assistance from the World Bank, reviewed the public expenditure program, identifying and eliminating projects of doubtful economic value and formulating a core investment program compatible with the changing resource availability and policy objectives of the authorities. Specifically, government investments were redirected to build up the infrastructure needed to support private sector investment and to meet the needs of the social sectors, particularly education and health. At the same time, the planning, evaluation, and budgeting for public investment were significantly improved, with a view to increasing the efficiency of investment.

Toward the mid-1980s, arrears had accumulated primarily in connection with purchases of goods and services from public enterprises. Under the adjustment program, these arrears, which amounted to less than 0.2 percent of GDP, were eliminated in 1988, and improved monitoring procedures prevented the accumulation of new arrears.

The overall budget monitoring process was also strengthened substantially. The authorities computerized and centralized the monitoring of consolidated central government financial operations and introduced new procedures to allow the monitoring of disbursements of foreign loans as well as extrabudgetary operations financed by such loans. Furthermore, 19 Special Treasury Funds were incorporated into the 1987 budget and revenue earmarking was eliminated. The remaining special funds were constrained to operate within the limits of their own resources and those of budgetary transfers authorized in the budget law.

\section{Fiscal Outcome}

During 1986-92, the overall budgetary position of the Central Government fluctuated considerably in response to the continuing decline in petroleum revenue and the adverse effects of exogenous factors, including two successive years of drought (1988-89) and the Middle East crisis (1990-91). By 1992, however, it had strengthened significantly. Although the ratio of revenue to GDP declined steadily as the Government reduced its absorption of resources, it was more than offset by a contraction in the ratio of expenditure and net lending to GDP. During this period, the prompt policy adjustments of the authorities in response to changing circumstances contributed to the improved fiscal performance.

Total revenue declined from 34.6 percent of GDP in 1986 to 28.9 percent in 1992 , of which 3.1 percentage points were related to tax revenue. Almost all of the decline in tax revenue took place in 1987, the first full program year. Thereafter, the ratio of tax revenue to GDP remained at about 23 percent. The analysis of the tax performance suggests that, with the implementation of tax reforms and the strengthening of the tax administration, the tax system in 1991-92 was substantially more buoyant than in the early part of the program period. Furthermore, the concerns that the tax reforms would be 
initially detrimental to revenue performance do not appear to have been borne out.

During 1987-92, the ratio to GDP of taxes on income and profit remained at about 4 percent, and of taxes on goods and services at about 7 percent. The ratio of taxes on foreign trade to GDP fluctuated from year to year, mirroring movements in the imports-to-GDP ratio. However, because of the reductions in customs duties under the trade reform, the ratio of trade taxes to GDP did not show the significant increasing trend seen in the imports-toGDP ratio. Over the program period, nontax revenue declined more or less steadily, by about 2.6 percentage points of GDP, reflecting the decline in petroleum revenue. Petroleum revenue consisted of the Government's share of the receipts of crude oil exports and other operating surpluses paid by the government petroleum companies, contributions in kind from different oil fields, and the receipts of a surtax paid by the petroleum companies.

In terms of revenue composition, the share of tax revenue in the total increased while that of nontax revenue declined during the adjustment period. Taxes on foreign trade remained the most important source of tax revenue, the share of which increased slightly despite the lowering of average customs duties. The share of taxes on goods and services, which declined early in the program period, increased significantly after 1989 when the VAT became fully operational and its base was extended to wholesale trade activities. The share of taxes on incomes and profits did not show a particular trend, with fluctuations remaining between 12 percent and 14 percent.

Total expenditure and net lending, which amounted to about 40 percent of GDP on average during the first half of the 1980 s, declined steadily under the adjustment program, from 39.2 percent in 1986 to 31.9 percent in 1992. Most of this decline was accounted for by reductions in capital expenditure and net lending, reflecting the difficulties the authorities encountered in cutting current expenditure.

In current expenditure, the authorities brought the wage bill below 10 percent of GDP starting in 1987 and reduced it to 9.3 percent in 1992 by imposing a wage freeze early in the program period, signing a three-year wage agreement, and limiting new hiring. Subsidies and transfers showed an increasing trend during 1987-89, mainly because of larger transfers by social security schemes to households, increases in transfers to schools and hospitals for current outlays, and higher consumer subsidies in 1988-89 to compensate for two years of drought and high international cereal prices. Between 1989 and 1992, the ratio of subsidies and transfers to GDP declined by 2.1 percentage points, to reach 10.5 percent of GDP in 1992, as transfers to public enterprises declined and consumer subsidies were reduced. The reduction in consumer subsidies resulted from the phasing out of subsidies on fertilizers and from increases in prices. Expenditure on goods and services, which had peaked at some 5.6 percent of GDP in 1983, was maintained at about 2 percent of GDP during 1988-92.

Under the program, capital investment and net lending as ratios to GDP were also sharply reduced. Direct investment by the Government, which was largely limited to economic infrastructure to support private sector activity, was held at about 4 percent of GDP, except in two years when it exceeded 5 percent-in 1988, owing to an increase in rural projects to alleviate the adverse effects of the drought, and in 1991, owing to an expansion in projects directly financed from abroad. Capital transfers and net lending declined more or less continuously from the beginning of the program period, as investment programs of public enterprises were scaled down significantly, in line with the objective of reducing the share of the public sector in total investment, and as the restructuring of public enterprises reduced their need to borrow from the Government. The decline more than offset the transfers that went toward financing the restructuring of public enterprises.

The share of current expenditure in the total increased by about 7 percentage points during 1986-92, to reach some 80 percent in 1992, while the shares of capital expenditure and net lending declined correspondingly. Within current expenditure, the share of interest payments on public debt grew steadily, as the outstanding level of debt rose and the deficits were financed increasingly at market-determined interest rates. The decline in the share of capital expenditure was almost totally attributable to the decline in capital transfers.

Mirroring developments in revenue and expenditure, the overall budget deficit of the Central Government, including grants, remained in the range of 3.9-5.4 percent of GDP in 1986-91 before declining to 2.6 percent in 1992. Excluding interest payments, the overall fiscal balance in 1992 recorded a surplus, amounting to 0.5 percent of GDP, for the first time in recent years. The 1988-89 drought was responsible for the deterioration in the overall budgetary position, excluding grants, although its impact on the budget was attenuated in 1989 by the inflows of drought-related grants. The budget deficit widened again in 1991, when the Government stepped up its investment to mitigate the adverse economic impact of the Middle East war. In both instances, the deterioration was reversed in the following year thanks to the authorities' prompt policy actions. 
The share of the budget deficit financed from foreign sources declined during 1986-92, while that from domestic sources, in particular the nonbanking sector, increased. Net foreign financing, which covered on average more than three fourths of the budget deficit in the first half of the 1980s, declined to 6.2 percent in 1992, except in 1991 when direct foreign financing for investment projects increased substantially. The share of the budget deficit financed by the domestic banking system also fell from about 23 percent in 1986 to 7 percent in 1991 before turning negative in 1992. Meanwhile, nonbank domestic financing became the main source of budgetary financing. Initially, nonbank financing was largely in the form of low-interest development bonds subscribed to by institutional investors (insurance companies, social security funds, and the National Saving Fund). As part of the financial sector reforms, the Government started in 1989 to issue treasury bills with market-related interest rates, which are held by individuals and nonbank institutional investors. Furthermore, the Government accelerated the amortization of the outstanding development bonds, which further boosted the cost of outstanding domestic debt.

\section{Social Issues and Protection}

Tunisia accorded great emphasis to social development, poverty reduction, and family planning, as well as to the protection of the population through an extensive social security system consisting of several funds. During the 1980s, the social indicators in Tunisia improved significantly and are currently better than in many other countries at similar income levels (see Table 2). Comparisons of data at the beginning of the 1980 s with those of the beginning of the 1990s show that primary school enrollment, as a ratio of the total number of primary school-aged children, increased from 103 percent to 115 percent; secondary school enrollment, as a ratio of the total number of secondary school-aged children, increased from 27 percent to 44 percent; the illiteracy rate declined from 54 percent to 35 percent; the proportion of the population living in absolute poverty was halved, to 6 percent; the infant mortality rate declined from 72 per thousand to 44 per thousand; and population growth slowed down from over 2.7 percent a year to below 1.8 percent.

During the adjustment period, the Tunisian authorities took measures to alleviate the hardships for the poorest segments of the population and to foster the development of the social sectors. They reduced consumer subsidies by raising prices on the goods that constituted the smallest proportion of the purchases of the poor, and by targeting subsidies and direct income support more effi- ciently. Furthermore, government investment was redirected, and the bulk of the increase in the number of civil servants was aimed at meeting the needs of the social sectors, particularly education and health. Finally, the improvements in the growth performance of the economy during the adjustment period provided increased employment opportunities that prevented the unemployment rate from rising.

In addition to implementing measures to protect the poorest segments of the population and to develop the social sectors, the authorities took steps to improve the social security system and strengthen the social safety net. Their goals in terms of the social security system were to (1) improve the financial viability of the systemadversely affected by a declining population growth rate-by restructuring the various funds; (2) harmonize benefits and premiums; and (3) broaden its coverage to include the selfemployed and workers in the agricultural sector. Furthermore, the criteria for defining needy families were reviewed, and, on that basis, revisions were proposed with a view to improving the allocation of direct income support. Meanwhile, the authorities undertook a detailed survey of the poorer segments of the population with the goal of identifying individuals whose economic potential could be realized through training.

\section{Outstanding Issues}

The authorities intend to increase government savings further, so as to continue releasing resources to the private sector, and to improve the efficiency of public expenditure. Accordingly, they plan to implement revenue-enhancing and expenditurecontaining measures as well as to restructure government expenditure.

The authorities' revenue-enhancing plans include broadening the tax base, adapting the tax system to the changing structure of the economy, and strengthening the tax and customs administration. The VAT and income taxes will be broadened through a more vigilant treatment of small and medium-size enterprises. The VAT can also be extended to the retail stage to close the circuit of goods and services from the importation and production stage through the retail level. This step will also help strengthen tax control by providing crosschecks in commercial operations for tax purposes. In addition, the scope of lump-sum taxes can be narrowed if more categories of taxpayers are brought under the general tax regimes.

The informal sector in Tunisia is expanding rapidly, eroding the tax base. The authorities are 
Table 2. Social Indicators

(In percent, unless otherwise indicated)

\begin{tabular}{|c|c|c|c|}
\hline & 1980 & 1985 & 1990 \\
\hline Primary school enrollment/primary school-aged children' & 103.0 & 116.0 & $116.0^{2}$ \\
\hline Secondary school enrollment/secondary school-aged children & 27.0 & 39.0 & 45.0 \\
\hline Illiteracy rate ${ }^{3}$ & 53.5 & 42.4 & 34.7 \\
\hline Pupils per teacher (primary school) & 38.5 & 31.6 & 27.8 \\
\hline \multicolumn{4}{|l|}{ Infant mortality rate } \\
\hline (per thousand live births) & 72.4 & 54.8 & 44.4 \\
\hline Life expectancy at birth (in years) & 61.9 & 64.6 & 67.3 \\
\hline Population per physician (number of people) & $3,694.4$ & $2,161.9^{4}$ & $1,872.4^{5}$ \\
\hline Population growth rate & 2.7 & $2.4^{4}$ & $2.0^{5}$ \\
\hline Population living in poverty/total population & 11.1 & 7.0 & 5.7 \\
\hline Urban population/total population & 52.2 & 53.0 & $55.0^{5}$ \\
\hline
\end{tabular}

Source: World Bank, Social Indicators of Development, data base.

'The ratio exceeds 100 percent because some pupils are younger or older than Tunisia's standard primary school age.

IIn 1989.

${ }^{3}$ As a percentage of the population 15 years and older.

4 In 1986.

51992 .

considering measures to bring this sector within the tax net, including enforcing business license fees. In addition, the surveys being conducted by the tax department to identify individuals in the informal sector and to register them as taxpayers will provide useful information.

The authorities are also focusing on improving tax assessment and collection procedures and reinforcing tax auditing operations. In early 1993, the Ministry of Finance launched a taxpayer information campaign through the media and sent direct mail notices to advise taxpayers about their tax obligations. Simultaneously, the tax department intensified its efforts to collect arrears from delinquent taxpayers. The tax department's computer system will also be improved and centralized to follow up taxable operations.

On the expenditure side, the authorities intend to contain the growth of the wage bill and reduce low-priority expenditure while continuing to meet the needs of the social sectors and improve the infrastructure. Envisaging a major reform of the civil service, they are currently evaluating its status and recommending improvements in recruitment procedures, staff training, the wage system, promotion rules, incentives, and sanctions. The survey of the entire civil service is aimed at establishing the identity, status, and job position of civil servants, as well as the total number in each department. A new salary scale will replace the existing system of base salary and automatic indemnities, and an incentive system based on merit is expected to be developed. The authorities hope to complete these reforms as early as possible to provide a basis for redeploying civil servants, limiting recruitment, and linking remunerations more closely with productivity so as to be able to achieve their objective of reducing the share of the wage bill in the budget.

To improve social conditions, the authorities plan to (1) provide adequate resources for social sectors; (2) target subsidies to the poorer segments of the population more efficiently; and (3) broaden the social security system to cover the self-employed and workers in the agricultural sector. They intend to complement these efforts by reducing unproductive expenditure. Better targeting of consumer subsidies should allow reductions in the overall level of consumer subsidies, and the results of the survey of needy families should allow the Ministry of Social Affairs to improve the allocation of direct income support. In addition, budgetary transfers can be reduced through improved cost recovery for public utilities and a strengthening in the financial position of the public enterprise sector.

Other items on the authorities' agenda include improving the timeliness and coverage of fiscal data so as to improve the monitoring of budgetary operations. They are focusing particularly on the collection of budgetary data and on the monitoring of direct, foreign-financed investment. 


\section{Monetary Policy and Financial Sector Reforms}

\section{$\mathbf{T}$} he system of monetary management in place at the beginning of the 1980 s was characterized by controls on the volume and composition of credit as well as on interest rates, which proved ineffective in influencing overall credit expansion yet resulted in severe distortions in resource allocation.

The Central Bank's main instruments of monetary control were the credit rediscount facilities. Commercial banks' total access to rediscounting was officially constrained by a global limit, defined as a ratio of their deposit holdings. The cumulative rediscount available was equivalent to 15 percent of a bank's deposits; rediscounting of more than 15 percent of deposits up to 17.5 percent of deposits was subject to a higher overdraft rate, and rediscounting of more than 17.5 percent was subject to a penalty rate. In addition, credit for specific purposes, such as financing exports, was not limited because it was rediscounted by the Central Bank outside the rediscount ceilings. Furthermore, different refinancing facilities were operated for credits to the cereal, wine, and olive oil sectors as well as for medium-term housing loans, which were accorded preferential interest rates and were not counted in the rediscount ceiling.

The composition of the volume of credit was regulated through various ratios, of which the most important one was the total ratio of development financing. Banks were required to lend 43 percent of their total deposits (excluding foreign currency deposits of nonresidents and convertible dinar deposits) in the form of medium- and long-term loans. This ratio was further disaggregated, such that a minimum of 25 percent of total deposits had to be held in public sector bonds, of which 20 percent were in ten-year treasury investment bonds, and 5 percent in bonds issued by the housing savings bank, Caisse nationale d'épargne logement. The remaining 18 percent had to be allocated to medium-term loans for the private sector, including loans to priority sectors (agriculture, exports, small and medium-size enterprises, and certain public enterprises). Individual loans of more than D 1.0 million for most short-term commercial credits and for short-term financing of agricultural, manufac- turing, and mining activities required the Central Bank's approval, while the rediscounting of loans of more than D 100,000 required a prior agreement with the Central Bank.

The structure of interest rates was also directly controlled. Lending rates were classified into three categories: (1) preferential rates to priority sectors; (2) normal rates for loans to nonpriority sectors; and (3) penalty rates for activities deemed nonproductive. Interest rates remained constant over long periods of time, and, with the pickup in inflation in the early 1980 s, first preferential rates and later other lending and deposit rates became increasingly negative in real terms.

The reduction in the obligatory reserve requirement from 3 percent of deposits to zero in 1982 led to a large potential for monetary creation by commercial banks. Thus, to the extent that new loans returned to the banking system as new deposits, the Central Bank's efforts to control liquidity in the Tunisian economy by limiting rediscounting did not contain monetary expansion. This problem was compounded by the unlimited rediscounting outside the ceiling, which in 1985 accounted for about 50 percent of all rediscounts, and by the maintenance of negative real interest rates, which simultaneously stimulated credit demand and penalized financial savings.

Between 1980 and 1984, rediscounts increased at an average rate of 42 percent a year, owing mainly to rediscounts to priority sectors. Credit and monetary expansion, in turn, increased rapidly, with the growth of domestic credit exceeding that of money. The excessive credit creation, together with the impact of drought, a deterioration in the terms of trade, and depressed receipts from tourism, resulted in a rapid erosion of net foreign assets. By mid-1986, Tunisia's once comfortable gross foreign exchange reserves were almost depleted. In addition, the direct credit controls and negative real interest rates endangered the soundness of the banking system by directing credit toward lowreturn priority sectors without taking into account the recoverability of such loans. It was only in 1985 that the Central Bank raised interest rates enough 
to make real interest rates on long-term deposits positive; preferential rates, however, remained significantly negative in real terms.

\section{Monetary Policy}

Against this background, the adjustment program initiated in 1986 aimed at reducing the rates of growth of domestic credit and broad money consistent with the economic growth, inflation, and balance of payments objectives, while simultaneously redirecting financial resources to the private sector from the public sector. To achieve these objectives, the Central Bank relied increasingly on indirect monetary instruments.

\section{Policy Instruments}

At the beginning of 1987, the Central Bank curtailed the amount of refinancing to commercial banks and increased to D 5 million from D 1 million the loan amount for which prior approval was necessary. Although the Central Bank tightened the refinancing ratio for banks to 14 percent of total deposits, loans to priority sectors at preferential rates continued to be eligible for rediscounting, and thus constituted a more attractive source for liquidity than the money market. At the beginning of 1988, the prior approval requirement for loans, the prior authorization requirement for rediscounting, and all the refinancing facilities except for priority sectors were abolished. In November 1988, the Central Bank changed its rediscount policy again and required that commercial banks deposit all liquidity obtained from rediscounting with the Central Bank, earning the money market rate of interest. This measure helped to curtail the creation of excess liquidity.

Interbank operations in the money market started in 1987. However, except for 1988-89, when bank liquidity improved as a result of a sharp rise in tourist receipts following the reopening of the border with the Socialist People's Libyan Arab Jamahiriya, the level of interbank credit remained depressed because of the structural liquidity shortages of the commercial banks, which were also affected by the sterilization of liquidity obtained through refinancing. In 1988, the Central Bank started supplying liquidity to the money market through two main channels: a weekly auction of a fixed amount of seven-day liquidity against assets held by the banks and a seven-day repurchase facility. Furthermore, the Central Bank could intervene through overnight repurchase agreements at prevailing market conditions, although these were seldom used. The seven-day repurchase facility was designed to penalize banks whose residual liquidity needs exceeded the auctioned liquidity; banks could obtain additional liquidity, but at a rate of interest higher than that on auctions. In principle, access to the repurchase facility was automatic and unlimited, but, in practice, the Central Bank could apply moral suasion to curtail the commercial banks' demands. ${ }^{1}$ In 1992, the Central Bank established a further refinancing window through the rediscount of letters of credit in foreign exchange, allowing banks to benefit from lower international rates of interest.

In the meantime, additional efforts to prevent the creation of excess liquidity continued outside the money market. In June 1989, the Central Bank raised the general reserve requirement from zero to 2 percent of deposits. From October 1989 to the end of 1990, banks were required to deposit in a non-interest-bearing account at the Central Bank all deposits growing in excess of a given rate, determined on a monthly basis by the Central Bank. In a further effort to mop up excess liquidity and dampen the demand for money, the authorities introduced treasury bills in 1989 .

Substantial changes were made in the level, structure, and determination of interest rates under the reform program. In January 1987, a significant reduction in the number of rediscount rates was implemented. Lending rates were allowed to move up by $1.0-1.5$ percentage points and were made subject to a ceiling of 3 percentage points over the money market rate. All deposit rates were liberalized, except those designed to offer incentives for small savings accounts; the latter were set at the money market rate minus 2 percentage points. Other deposit rates increased from levels of 4.510.0 percent to $7.0-11.0$ percent, with real interest rates becoming positive after these adjustments.

In 1991, the approach used for determining the ceiling on lending rates was changed; the new method was based on bank-wide averages of lending rates, with the result that the rates of individual loans could be determined freely as long as the bank-wide average did not exceed the money market rate plus 3 percentage points. The level of preferential interest rates was increased a number of times, gradually narrowing the gap between these rates and the money market rate. Furthermore, the number of activities eligible for preferential credit was reduced twice, in 1990 and 1992, so that by the end of 1992 only 10 percent of total credit was

\footnotetext{
${ }^{1}$ For example, during 1990 the Central Bank, in an effort to control liquidity expansion, discouraged commercial banks from using the repurchase facility. Instead, the banks involved had to refinance at the penalty rate on overdrafts, which is the money market rate plus 5 percentage points.
} 


\section{Chart 2. Interest Rates, January 1988-March 1993}

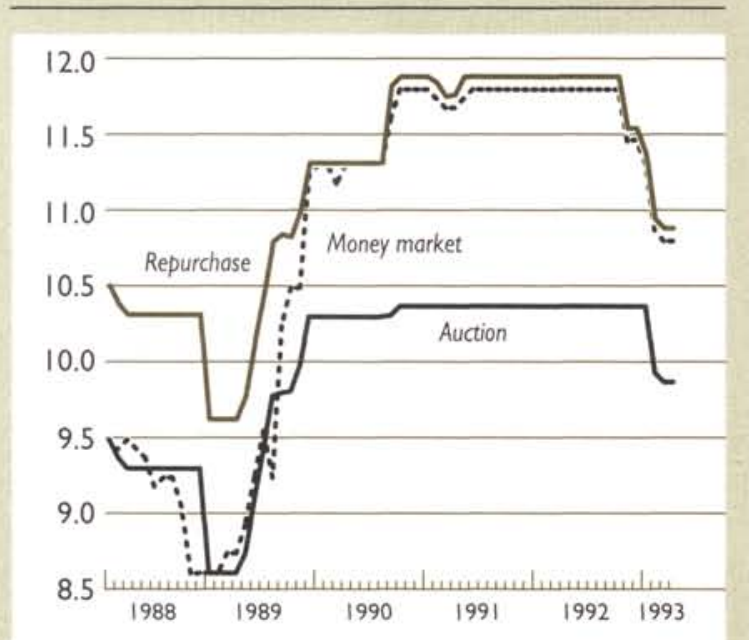

Source: Central Bank of Tunisia.

accorded at the preferential rates, which by then ranged from 10 percent to 11 percent (compared with the money market rate of 11.8 percent).

The Central Bank had two ways of influencing interest rates. First, it retained control of preferential interest rates, which were applied to one fourth of total credit at the beginning of the adjustment program. Second, the Central Bank essentially determined the money market rate through auctions and the repurchase facility. The money market, however, exhibited some rigidities, as evinced by the fact that the rate at auctions did not clear the market and remained fairly stable (Chart 2). The balance of the credit needs not met through auction was satisfied through the repurchase facility at a rate of $1.0-1.5$ percentage points above the auction rate. After August 1990, the repurchase facility was the most important source of refinancing.

\section{Monetary Developments}

Through monetary policy, the authorities succeeded in limiting the average growth of the money supply to below that of nominal GDP during 198692. Two phases of monetary policy reform can be distinguished. In the first phase, from 1986 to the beginning of 1990, interest rates were increased enough to check the growth in domestic credit and currency in circulation and demand deposits (M1). Starting in 1990, the money market rate was adjusted only infrequently. With the phasing-in of treasury bills, however, the growth in net credit to the Government was further reduced, thereby helping to maintain the growth of broad money (M2) below that of nominal GDP while simultaneously redirecting credit to the private sector. ${ }^{2}$

The tightening of monetary policy is evinced by the movements in the velocity of money (Chart 3 ). The trend toward a falling velocity in the first half of the 1980s was successfully reversed in 1986, when the growth of M2 decelerated sharply. The velocity of M1 increased in 1987 and, after a fall in 1988, maintained an upward trend, reflecting in part positive real interest rates. The turnaround of the declining trend in the velocity of M2 became evident with the increased placement of treasury bills with the nonbank public starting in late 1989. The shift in the allocation of financial resources is illustrated by changes in the composition of total domestic credit (Chart 3). From 1987 onward, except in 1990, the share of credit to the private sector in domestic credit increased while the rate of growth of domestic credit was reduced to a sustainable level.

Although the monetary adjustment in 1986 was achieved through a heavy reliance on direct credit controls, the Central Bank realized that the resulting distortions dampened economic growth. Therefore, the aforementioned changes in refinancing and interest rate policy were introduced. With the substantial increase in interest rates during 1987, the opportunity cost of holding cash balances increased, and, as a result, the holdings of M1 fell by 1.8 percent (Table 3 ). This drop was offset by a strong increase of the interest-earning components of M2, so that the overall expansion of M2 kept pace with that of nominal GDP. However, exogenous factors continued to exert a toll on the Tunisian economy, for example, the 1988 drought that reduced nominal GDP growth to 8.6 percent. Meanwhile, the strong increase of foreign currency receipts, owing to the reopening of the border with Libya, contributed to a rise in the growth of M2, to 19.2 percent. In November 1988, the Central Bank curbed the steady increase in refinancing through the rediscounting of preferential credits by introducing the sterilization of liquidity obtained through refinancing.

In 1988, the monetary authorities were able to initiate a shift in the composition of domestic credit toward the private sector. In 1989, further credit expansion to the private sector supported a strong recovery in domestic investment, whereas overall monetary expansion was checked through the

2The private sector in the monetary accounts is defined to include all economic agents other than the Central Government. 
institution of a marginal reserve requirement, significant increases in the money market rate (from 9.0 percent to 11.3 percent), and, toward the end of the year, the introduction of treasury bills. The latter were successful because of their attractive remuneration (the first treasury bill issue was placed at an interest rate of 8.3 percent, when the money market rate was 10 percent), and because a change in the regulatory framework allowed commercial banks to include the sale of treasury bills to the nonbank public in their requirement to hold treasury paper. ${ }^{3}$ The continued pursuit of a prudent credit policy in 1990-91 mitigated the impact on the external position of the Middle East crisis and of the worsening terms of trade.

In 1992, a sharp increase in stocks of cereals and olive oil (representing a bumper harvest) as well as in the stocks of phosphates (owing to a glut on the world market) contributed to a 15.5 percent increase in credit to the private sector. However, with a further expansion of budget financing through treasury bills, net credit to the Government declined, limiting the overall increase in credit to 11.8 percent. Benefiting from a 2 percentage point reduction in inflation, the money market interest rate fell by 0.5 percentage point in November. Even so, the fall in inflation translated into higher positive real interest rates, and the cap on lending rates did not appear to be effectively binding. Overall, the growth of M2 was held to 8.2 percent in 1992 , well below the growth in nominal GDP.

\section{Financial Sector Reforms}

An immediate objective of the adjustment program was to improve monetary management, and a medium-term objective was to redress the problems in the financial sector. ${ }^{4}$ The efficiency of the

\footnotetext{
${ }^{3}$ The initial treasury bill subscription, in the last quarter of 1989, amounted to D 172 million, with D 124 million being placed with the nonbank public. Moreover, in September 1991, a directive was issued requiring banks to repurchase treasury bills at rates to be posted daily. In practice, the banks repurchase these bills at face value with only a nominal commission charged. Thus, treasury bills, although nonnegotiable, became highly liquid.

${ }^{4}$ The Tunisian financial system consists of the Central Bank, 12 deposit money banks, 8 development banks, 1 institution specializing in savings, 7 offshore banks, 5 portfolio management companies, and 3 leasing institutions. The two largest deposit money banks, Banque nationale agricole and Société tunisienne de banque, are owned by the public sector. In 1989, a large development bank merged with a deposit money bank, and the specialized savings institution was transformed into a deposit money bank. Furthermore, Citibank, which until then had been active only in the offshore banking sector, opened an onshore deposit banking branch.
}

\section{Chart 3. Monetary Performance'}
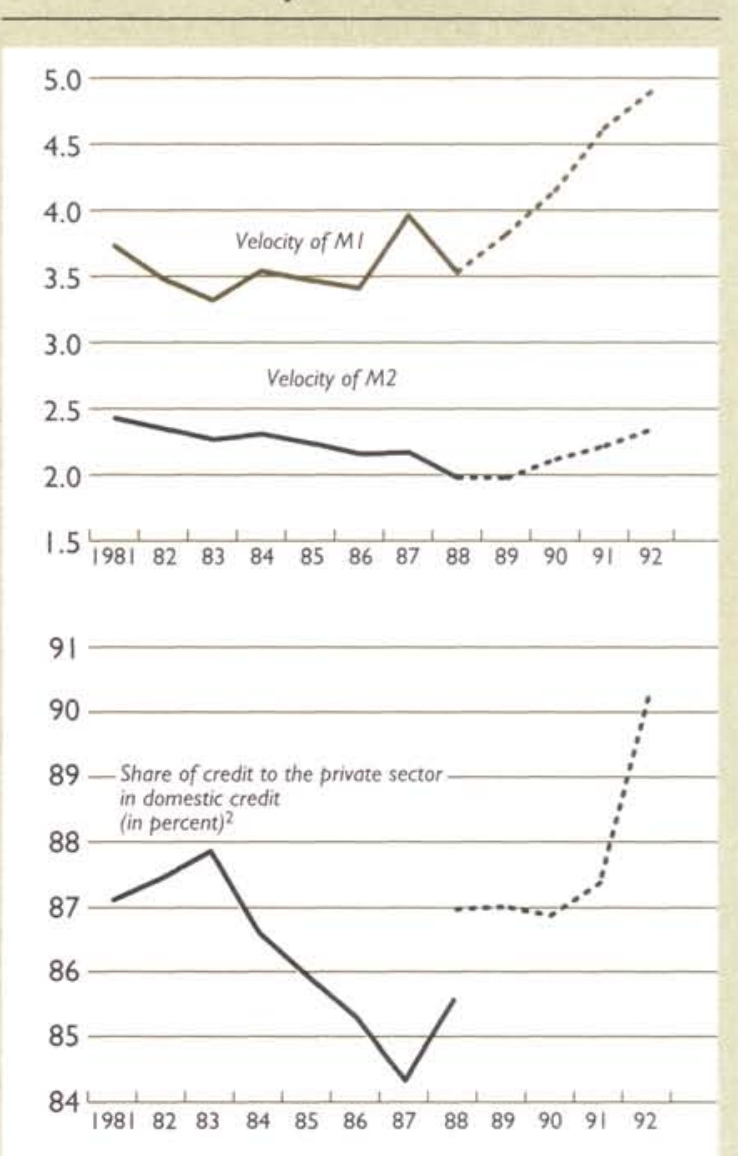

\footnotetext{
Source: Central Bank of Tunisia.

The break in the series is due to regroupings in the banking sys. tem in 1989

2 The private sector is defined to include all economic agents other than the Government.
}

banking system had suffered over the years from the regulatory framework, particularly from the negative real lending rates and the asset composition requirements that made lending to certain low-yield activities mandatory. As a result, a number of banks started to encounter liquidity problems and increasingly carried nonperforming loans in their portfolios. Furthermore, the financial markets remained rudimentary. As an integral part of the adjustment program, the authorities wanted to promote effective resource mobilization and efficient resource allocation by reforming the financial system. The main elements of the reform were the further development and deepening of financial markets, through the introduction of new instruments and the elimination of distortions; the strengthening of prudential regulations; and the enhancement of the role of market forces. 


\section{Table 3. Basic Monetary Indicators \\ (Annual change in percent)}

\begin{tabular}{|c|c|c|c|c|c|c|c|c|c|c|c|c|}
\hline & 1981 & 1982 & 1983 & 1984 & 1985 & 1986 & 1987 & 1988 & 19891 & 1990 & 1991 & 1992 \\
\hline Domestic credit & 24.3 & 23.4 & 19.4 & 15.3 & 17.2 & 8.3 & 7.9 & 1.9 & 7.2 & 10.4 & 9.7 & 11.8 \\
\hline Net credit to the Government & 16.5 & 20.1 & 15.5 & 27.3 & 23.0 & 13.2 & 15.0 & -6.2 & 6.6 & 11.9 & 5.6 & -13.3 \\
\hline Credit to the private sector & 25.6 & 23.9 & 19.9 & 13.7 & 16.3 & 7.5 & 6.7 & 3.3 & 7.3 & 10.2 & 10.4 & 15.5 \\
\hline Money plus quasi money (M2) & 19.5 & 19.0 & 18.6 & 11.6 & 13.9 & 5.7 & 13.7 & 19.0 & 11.0 & 6.3 & 5.5 & 8.2 \\
\hline Money (Mi) & 17.3 & 23.7 & 19.9 & 6.7 & 12.6 & 3.5 & -1.8 & 21.6 & 2.7 & 4.9 & -0.4 & 7.4 \\
\hline Quasi money & 23.6 & 10.3 & 15.9 & 22.0 & 16.2 & 9.5 & 39.9 & 16.3 & 21.5 & 7.9 & 11.5 & 8.9 \\
\hline Net foreign assets & 23.5 & 6.9 & 54.4 & -25.7 & -30.4 & -73.3 & 228.6 & 202.1 & 23.2 & -8.3 & -14.0 & -4.3 \\
\hline \multicolumn{13}{|l|}{ Velocity } \\
\hline MI & $\ldots$ & -6.7 & -4.5 & 6.4 & -1.9 & -1.6 & 16.0 & -10.7 & 8.3 & 8.5 & 11.4 & 6.3 \\
\hline M2 & $\ldots$ & -3.0 & -3.5 & 1.7 & -3.0 & -3.6 & 0.3 & -8.9 & 0.2 & 7.0 & 5.2 & 5.6 \\
\hline \multicolumn{13}{|l|}{ Memorandum items: } \\
\hline \multicolumn{13}{|l|}{ GDP } \\
\hline Nominal & $\ldots$ & 15.4 & 14.4 & 13.5 & 10.4 & 1.9 & 13.9 & 8.6 & 11.2 & 13.8 & 11.0 & 14.2 \\
\hline Real & $\ldots$ & -0.5 & 4.8 & 5.7 & 5.5 & -1.1 & 6.7 & 0.1 & 3.7 & 7.6 & 3.9 & 8.0 \\
\hline GDP deflator & 11.2 & 16.0 & 9.3 & 7.3 & 4.9 & 2.6 & 6.7 & 8.5 & 7.2 & 5.7 & 6.8 & 5.8 \\
\hline CPI & 8.9 & 13.7 & 9.0 & 8.6 & 7.6 & 6.2 & 8.2 & 7.2 & 7.7 & 6.5 & 7.8 & 5.5 \\
\hline
\end{tabular}




\section{The Development of Financial Markets}

To encourage direct financing through financial markets and to enhance the effectiveness of indirect monetary instruments, the authorities introduced new financial instruments and made them more flexible. In 1988, commercial paper issued by nonfinancial institutions and certificates of deposit issued by commercial banks were introduced. On the capital market, open- and closed-end mutual funds were set up in 1988, while treasury bills were introduced in late 1989. In 1991, the Treasury stopped issuing lowinterest-earning, long-maturity investment bonds. In 1992, three new financial instruments were introduced: investment trusts with a minimum capital requirement of D 10,000 , priority shares without voting rights, and equity loans for the purpose of raising capital funds for restructuring.

The market for commercial paper started at a modest pace, which picked up when additional reserve requirements and tight credit controls were introduced in 1989 (Chart 4). Commercial paper with a minimum maturity of ten days was issued by nonfinancial institutions with a minimum capital of D 1 million. In contrast, the market for certificates of deposit experienced a spurt of activity after its introduction because enterprises perceived them as a way of temporarily placing balances that would otherwise not have been earning interest. Certificates of deposit, which initially had a minimum maturity of 10 days that was subsequently revised to 90 days, earned an interest rate equal to, or slightly above, the money market rate.

Since August 1990, the volume of outstanding certificates of deposit has declined dramatically with the development of the treasury bill market. Treasury bills were introduced in several stages: those with a maturity of 13 weeks in October 1989; those with maturities of 26 weeks and 52 weeks in early 1990; those with maturities of two years and five years in December 1991; and those with a three-year maturity in February 1992. The treasury bills were issued through an auction system. Banks were encouraged to purchase and place these bonds with the nonbank public. Furthermore, at the time, the marginal reserve requirement on deposits exceeding a targeted rate of growth increased the incentive for banks to sell treasury bills to the public rather than to hold new deposits.

In addition to developing a wider array of financial instruments, the authorities also embarked on a program to reduce the distortions resulting from the difference in the fiscal treatment of those instruments. Between 1986 and 1990, the authorities gradually eliminated the multiple taxation of equity financing by exempting distributed dividends from corporate taxation. The applicability of

\section{Chart 4. Evolution of Financial Instruments, November 1989-March 1993}

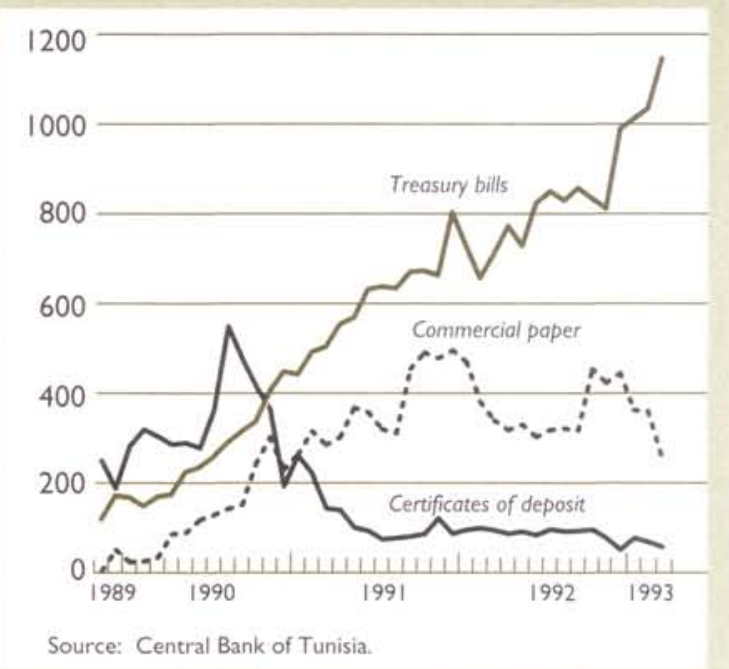

this treatment to mutual funds was clarified in the 1992 budget law. Concurrently, the different tax treatment of bonds held to maturity and those traded on the secondary market was discontinued.

\section{Bank Restructuring and Reforms}

The quality of the banks' balance sheets suffered from the administrative regulation of interest rates, which for a time gave rise to negative real rates on lending, coupled with tight restrictions on asset composition favoring low-yielding investments. Although the interest rate reform of 1987 led to an increase in lending rates, thereby remedying some of these problems, banks that traditionally made loans to such priority sectors as agriculture and phosphates found themselves in a rapidly deteriorating financial position.

A series of independent audits, covering 80 percent of total assets of the banking system, was launched in 1992 to map out the magnitude of the restructuring needs of the banking system. Based on the findings, the risk ratio was set at 5 percent, and the loan concentration ratio was set initially at 40 percent but was reduced to 35 percent in early 1993. To facilitate the restructuring of the banks, the authorities adopted the following measures in 1992: the reduction of legal fees for the recovery of bad loans through court action, ${ }^{5}$ the tax exemption of

SBefore 1992, legal fees were calculated as a percentage of the bad loan in dispute and were due regardless of whether the loan could eventually be recovered or not. 


\section{Chart 5. Indicators of Financial Intermediation and Deepening' \\ (In percent)}
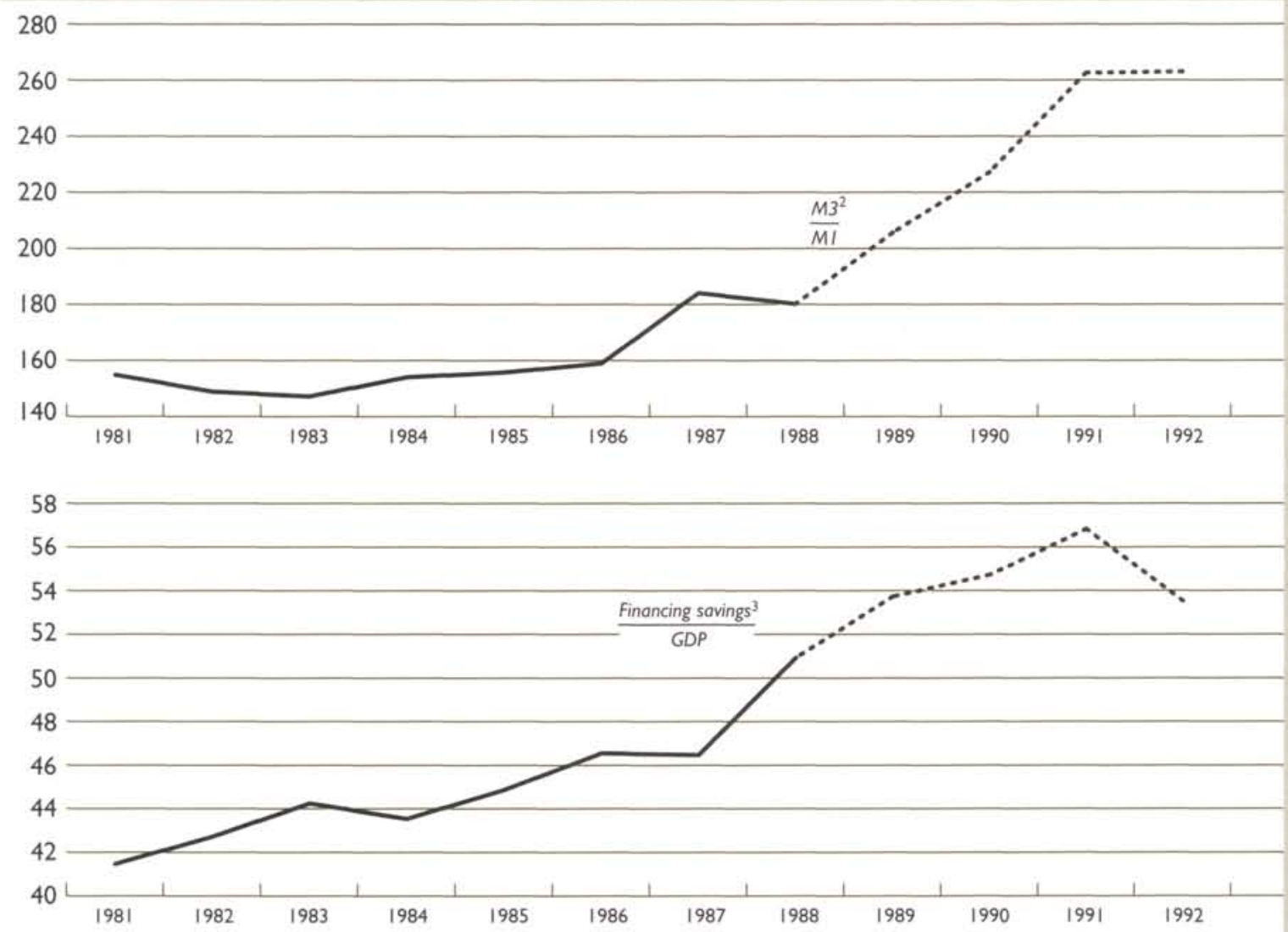

\footnotetext{
Source: Tunisian authorities.

IThe break in the series is due to regroupings in the banking system in 1989.

$2 \mathrm{M} 3$ is defined as money and quasi money (M2) plus bank bonds plus long-term deposits. $M 1$ is defined as currency in circulation plus demand deposits.

${ }^{3}$ Financial savings are defined as $\mathrm{M} 3$ plus outstanding stocks of treasury bills and commercial paper.
}

capital gains from the sale of shares, the tax exemption of interest arrears on loans in default, and the tax exemption of 40 percent of provisions (up from 30 percent). Concurrently, the authorities are stepping up monitoring and bank supervision activities.

\section{Impact of the Reforms}

This section addresses three questions. First, did financial intermediation increase and deepen as a result of the reform effort? Second, how has the development of treasury bills affected the demand for commercial paper and certificates of deposit? Third, what have been the repercussions of the development of the treasury bill market for monetary programming?
In addressing the first question, two indicators are examined. The first is the ratio of M3 to M1, ${ }^{6}$ which shows the relative importance of holding longerterm financial instruments as an indicator of the scope for financial intermediation. Chart 5 shows that this indicator rose significantly during the adjustment period. The second indicator, the share of financial savings ${ }^{7}$ in GDP, provides a measure of financial deepening. Chart 5 shows that this indicator also rose substantially during the adjustment period.

${ }^{6} \mathrm{M} 3$ is defined as M2 plus bank bonds plus other long-term deposits.

${ }^{7}$ Financial savings are defined as M3 plus the outstanding stocks of treasury bills held by nonbanks and commercial paper. 
For insight into the other two questions, demand equations for certificates of deposit, commercial paper, and M1 and M2 were estimated for the period November 1989-March 1993 using a linear reduced-form equation, with an iterative, maximumlikelihood Cochrane-Orcutt specification for firstorder serial correlation. The estimated equations, with all variables in log form, had the following general form:

$$
\begin{aligned}
y_{t}= & \alpha_{0}+\alpha_{1} t+\alpha_{2} D^{91}+\alpha_{3} D^{92}+\alpha_{4} L(y) \\
& +\alpha_{5} T B_{t}+\alpha_{6} T R E_{t}+u_{t},
\end{aligned}
$$

where $u_{t}=\rho u_{t-1}+\epsilon_{t}$ and $|\rho|<1$, where $\epsilon_{t}$ has the standard properties $\in \sim\left(0, \sigma_{\epsilon}^{2}\right)$.

In the equations, $y$ denotes the dependent variable, the outstanding stock of commercial paper $(B L T)$, or the outstanding stock of certificates of deposit (COD), or the holdings of M1 $(M 1)$, or the holdings of M2 (M2); $\alpha_{0}$, a constant; $t$, a time trend; $D^{91}$ and $D^{92}$, dummy variables for the Middle East conflict period 1991 and 1992, respectively; $L(y)$, lagged dependent variables; $T B$, the stock of outstanding treasury bills; TRE, the rate of interest on Ospecial savings deposits; and $u$, an error term with an autoregressive (AR1) structure. ${ }^{8}$

The main assumption underlying this exercise is the exogeneity of the outstanding stock of treasury bills and of interest rates. The assumptions can be justified by the fact that the issuance of treasury bills is determined by the financing requirements of the budget and that the Central Bank sets the money market interest rate, which in turn determines the deposit rate for special savings. Although the whole period covered in the estimation was good in terms of agricultural production, movements in nominal and real income growth have been affected by the Middle East crisis and variations in the growth rates in Tunisia's trading partners. Because national income data are available only once a year, income effects are, to a large extent, captured indirectly through the use of dummy variables for 1991 and 1992 . The results of the estimations are summarized in Table 4.

The results in column (1) of Table 4 indicate a positive and significant correlation between the stock of treasury bills and the outstanding amount of commercial paper, suggesting a complementarity in the development of these financial instruments. The estimates also show a positive relationship between the interest rate on special savings deposits and outstanding commercial paper. Because the interest rate on savings deposits

${ }^{8}$ Other specifications, in particular, with different lag structures, seasonally adjusted data, or monthly dummy variables, have been estimated, and showed the robustness of the reported results. is determined as a function of the money market interest rate, the demand for commercial paper increases in periods when the Central Bank is trying to limit access to credit by tightening conditions on the money market. The estimate of the constant is negative, suggesting a downward trend in the demand for commercial paper in the absence of the development of the treasury bill market and of pressures on interest rates in the money market. The second column of Table 4, which gives the estimated regression coefficients for the outstanding stock of certificates of deposit, shows a strong negative effect of the outstanding stock of treasury bills on the holdings of certificates of deposit, reflecting the more liquid nature of treasury bills relative to certificates of deposit with comparable interest rates.

The substitutability or complementarity of financial instruments needs to be taken into account in macroeconomic management as well, thereby leading into the third question. Column (3) reports the results of a regression of the demand for broad money. ${ }^{9}$ The stock of outstanding treasury bills has a negative and significant effect on the demand for broad money, however, with a small elasticity of -0.08 . In column (4), which reports the regression results for the demand for M1, the stock of outstanding treasury bills has a slightly larger negative elasticity, which, however, is only barely significant. In general, the demand for M1 is not explained as well by the previous regressions but conforms broadly to theoretical predictions of the effect of the savings deposit interest rate, which affects the holdings of M1 negatively but quasi money (M2 - M1) positively. The impact of treasury bills on money demand is important for monetary programming purposes: if treasury bills reduce the demand for money, monetary programming has to take into account that the achievement of a net foreign assets objective will require, other things being equal, lower growth in net domestic assets. Recognizing this relationship, the Central Bank and the Ministry of Finance have recently set up a coordinating committee to take into account in monetary programming the growth of the treasury bill market.

\section{Agenda for the Future}

In the period ahead, the Tunisian authorities intend to liberalize interest rates fully, abolish preferential lending rates, and increase the role of market forces in determining money market rates.

\footnotetext{
${ }^{9}$ Clearly, it would have been preferable to estimate a demand system for financial instruments where money is one instrument. However, given the lack of data for exogenous instruments, apart from treasury bills and the administered interest rate, the above approach was followed.
} 
Table 4. Regression Coefficients-Estimation of the Demand for Key Financial Instruments (t-statistics in parentheses)

\begin{tabular}{|c|c|c|c|c|}
\hline \multirow[b]{2}{*}{ Independent Variables } & \multicolumn{4}{|c|}{ Dependent Variable } \\
\hline & $\begin{array}{c}\text { (1) } \\
\text { Stock of } \\
\text { commercial paper } \\
(B L T)\end{array}$ & $\begin{array}{c}\text { (2) } \\
\text { Stock of } \\
\text { certificates of } \\
\text { deposit (COD) }\end{array}$ & $\begin{array}{c}(3) \\
\text { Stock of } \\
\text { broad money (M2) }\end{array}$ & $\begin{array}{c}(4) \\
\text { Stock of } \\
\text { narrow money }(M I)\end{array}$ \\
\hline Constant & $\begin{array}{c}-20.32 \\
(2.45)\end{array}$ & $\begin{array}{l}15.19 \\
(1.97)\end{array}$ & $\begin{array}{c}2.09 \\
(1.39)\end{array}$ & $\begin{array}{c}8.55 \\
(2.21)\end{array}$ \\
\hline Time trend & $\begin{array}{c}-0.02 \\
(0.67)\end{array}$ & $\begin{array}{r}-0.017 \\
(0.67)\end{array}$ & $\begin{array}{l}0.004 \\
(2.97)\end{array}$ & $\begin{array}{c}0.007 \\
(1.51)\end{array}$ \\
\hline Dummy for 1991 & $\begin{array}{l}0.062 \\
(0.32)\end{array}$ & $\begin{array}{l}-0.112 \\
(0.10)\end{array}$ & $\begin{array}{l}-0.01 \\
(1.29)\end{array}$ & $\begin{array}{l}0.026 \\
(1.33)\end{array}$ \\
\hline Dummy for 1992 & $\begin{array}{c}-0.059 \\
(0.23)\end{array}$ & $\begin{array}{c}-0.138 \\
(0.665)\end{array}$ & $\begin{array}{l}0.014 \\
(1.50)\end{array}$ & $\begin{array}{c}0.04 \\
(1.68)\end{array}$ \\
\hline$B L T(-1)$ & $\begin{array}{l}-0.16 \\
(0.83)\end{array}$ & & & \\
\hline $\operatorname{COD}(-1)$ & & $\begin{array}{c}-0.032 \\
(0.44)\end{array}$ & & \\
\hline$M 2(-1)$ & & & $\begin{array}{l}0.614 \\
(2.7)\end{array}$ & \\
\hline$M 2(-2)$ & & & $\begin{array}{c}-0.549 \\
(2.18)\end{array}$ & \\
\hline$M 2(-3)$ & & & $\begin{array}{l}0.364 \\
(2.09)\end{array}$ & \\
\hline$M 2(-12)$ & & & $\begin{array}{l}0.420 \\
(2.75)\end{array}$ & \\
\hline MI $(-1)$ & & & & $\begin{array}{c}0.257 \\
(0.584)\end{array}$ \\
\hline$M /(-2)$ & & & & $\begin{array}{c}-0.44 \\
(1.48)\end{array}$ \\
\hline MI $(-3)$ & & & & $\begin{array}{l}0.046 \\
(0.17)\end{array}$ \\
\hline$M I(-12)$ & & & & $\begin{array}{r}0.215 \\
(1.09)\end{array}$ \\
\hline$T B^{\prime}$ & $\begin{array}{c}1.50 \\
(2.55)\end{array}$ & $\begin{array}{l}-0.952 \\
(2.25)\end{array}$ & $\begin{array}{c}-0.08 \\
(2.59)\end{array}$ & $\begin{array}{l}-0.132 \\
(1.41)\end{array}$ \\
\hline TRE' & $\begin{array}{c}7.88 \\
(1.887)\end{array}$ & $\begin{array}{c}-1.59 \\
(0.45)\end{array}$ & $\begin{array}{l}0.013 \\
(0.086)\end{array}$ & $\begin{array}{l}-0.30 \\
(0.787)\end{array}$ \\
\hline Adjusted $R^{2}$ & 0.90 & 0.91 & 0.938 & 0.469 \\
\hline Durbin-Watson statistic & 2.046 & 1.9993 & 2.16 & 2.103 \\
\hline Durbin's $h$ & 0.5813 & 1.493 & $\ldots^{2}$ & 0.2511 \\
\hline
\end{tabular}

These measures should contribute to a more efficient allocation of scarce resources, and, together with the adaptation of the monetary programming framework to changing conditions in the course of the reforms, should make the conduct of monetary policy more effective. To further improve the soundness of the banking system, the authorities intend to continue strengthening banking supervision and prudential requirements. The development of the financial markets will also continue to benefit from the reforms already implemented and will receive an impetus from the ongoing privatization program, which will increasingly be pursued through the stock market. 


\section{Structural Reforms}

$\mathrm{n}$ the early 1980 s, the Tunisian economy was still largely controlled by the Government, which owned and managed a sizable share of productive assets, directly or through public enterprises. It also regulated the functioning of the economy. With a view to protecting the local industrial sector, the authorities had established a system of high and variable customs duties and quantitative restrictions on imports. At the same time, with a view to limiting inefficiencies, the small size of the market had often led the Government to discourage new entrants in non-import-competing activities, mainly through investment controls. With the small number of producers and distributors in many activities, competition in the domestic market was limited; this limitation was reinforced, in the case of tradable goods, by import restrictions.

A system of widespread price controls had been established to protect consumers from the impact of limited competition on prices. The system, under which prices were set on a cost-plus basis, thereby limiting profits, was not always successful in moderating inflation owing to its lack of incentives to control production costs. Concurrently, by keeping agricultural producer prices below international levels, the system did not promote agricultural production. Price controls were complemented by a system of subsidies that affected agricultural inputs and socially sensitive consumer goods, intended in part to protect the poorest segments of the population. The distortions generated by government regulation and the inefficiency of the public enterprise sector contributed to growing domestic and external financial imbalances in the early 1980 s.

\section{Objectives and Strategy}

The comprehensive structural reform program that the Government launched in 1986 aimed at improving resource allocation by moving the economy rapidly toward market orientation while fostering growth through an outward-oriented strategy to compensate for the limitations of the small domestic market. To achieve the increase in competitiveness needed for an export-led growth strategy to succeed, the authorities sought to strengthen overall productivity through greater competition while encouraging resource mobilization and channeling resources into productive investment. The main elements of the reform program were the liberalization of prices, trade, interest rates, and investment; the rationalization of investment incentives; and the reform of the public enterprise sector.

\section{Price Liberalization}

Up to 1986, the domestic prices of most goods in Tunisia, except nonessential agricultural products, were subject to control; services were generally free from control. The following five price systems, in descending degree of control, were in place: (1) a fixed price system, covering a limited number of essential food staples and some public utilities; (2) a cost-plus system (homolgation) under which enterprises submitted information to allow the authorities to establish appropriate prices; (3) an automatic cost-plus system (auto-homolgation), under which enterprises performed their own cost calculations according to a predetermined formula based on the product rather than on information pertaining to the enterprise concerned and supplied by it; (4) a system of controlled freedom under which cost calculations were performed by enterprises but were based on the formula of the cost-plus system; and (5) a free price system.

Agricultural producer prices were the first to be liberalized. At the beginning of 1986 , following several years of progressive removal of controls, about 75 percent of domestic agricultural production was sold freely in the domestic market or exported. For products remaining under control-particularly cereals, of which production was less than domestic consumption-the Government regularly adjusted producer prices, with increases exceeding the inflation rate so as to encourage domestic production.

Whereas producer prices had previously been determined mainly on the basis of estimated costs, in 1986 it was decided to adjust the producer prices of cereals according to a formula in order to reach 
parity with the cost of unsubsidized imports inclusive of freight and the minimum import duty of 15 percent. This objective was achieved in 1988. With the liberalization of meat prices, all agricultural producer prices, except for cereals and milk, have been freed from control. Although the producer price for olive oil is officially free, the sector is dominated by a public enterprise that purchases the oil at a preannounced producer price, thereby effectively setting the price.

After initiating the decontrol of agricultural producer prices in 1986, Tunisia embarked on the liberalization of producer prices in the manufacturing sector. The target was to free by 1991 all industrial prices at the production level, except for certain strategic and essential products, such as petroleum products, utilities, edible oils, and cereal derivatives. The pace of liberalization was to depend largely on the establishment of a sufficient degree of competition, assured either through a minimum number of domestic producers or through the decontrol of imports of similar products. In a first phase, between September 1986 and early 1988, during which imports were being liberalized rapidly, controls on manufacturing producer prices were lifted for products representing some 55 percent of manufacturing production. The pace of liberalization of industrial producer prices, however, slowed down somewhat in 1989-91. With the subsequent enactment of legislation on competition and distribution and further progress in removing import controls, the stage was set to accelerate the liberalization of producer prices in the manufacturing sector. By early 1993, the share of manufactured goods not subject to price controls had been brought to 87 percent of production.

In mid-1988, price liberalization was extended to cover the distribution stage, where margins were fully controlled, with the aim of removing controls on distribution margins for products representing 50 percent of domestic production by 1991. Progress in removing controls was to depend on two other steps: deregulation of the distribution sector, which would enhance competition; and liberalization of imports, because distribution margins for imported goods were to be removed after import controls were eliminated and competition for the domestic distribution of the goods had developed. As in the case of industrial producer prices, the pace of liberalization, which was initially somewhat slower than originally expected, picked up at the end of 1991. By early 1993, controls on distribution margins had been removed for products accounting for more than 75 percent of production, equivalent to some 70 percent of domestic absorption, compared with 30 percent in 1991.

The law on competition that became effective at the beginning of 1992 seeks to strengthen competi- tive conditions in the Tunisian economy by combating restrictive practices and promoting full disclosure of conditions governing commercial transactions. While establishing the principle of a free market determination of prices, the law retains the possibility of controlling the prices of essential goods and intervening in the case of insufficient competition. The number of price systems was reduced to two: (1) under the cost-plus system, which is applicable to either the production and distribution stages or only the production stage, the Government establishes a price for a certain product that applies to all producers and distributors in the sector or only to a given enterprise; and (2) under the automatic cost-plus system, which is applicable only to the distribution sector, enterprises establish their prices by applying a margin set by the Government. The law on domestic trade introduced in mid-1991 abolished the requirement that traders obtain authorization before engaging in retail and wholesale trading activities, thereby easing entry into the sector.

Under the Tunisian price system, subsidies were maintained on a wide range of consumer goods, including meat, cereal products, milk, sugar, and vegetable oil, as well as on certain agricultural inputs, such as seeds, animal feed, and fertilizers. The objectives of this policy were to moderate increases in the cost of living in general and to protect the lowest income groups while ensuring appropriate remuneration in the agricultural sector. Because this policy had led to higher budgetary costs, amounting to more than 4 percent of GDP in 1984 , and had stimulated consumption and distorted resource allocation, the Government decided to reduce the scope of subsidies gradually so as to limit them to essential consumer goods, mainly cereal derivatives and edible oils. The reduction in the subsidy bill was to be achieved by eliminating products and by periodically raising the price of subsidized goods, thereby gradually reducing the unit subsidy. Accordingly, meat was removed from the subsidized list in 1985, and prices of most other products were raised during 1985-87. As a result, the outlays on subsidies declined to 2.3 percent of GDP in 1987.

However, owing to high cereal import prices, the droughts in 1988 and 1989, and delays in price adjustments during those two years, the overall subsidy cost rose to 3.6 percent of GDP in 1989. In these circumstances, and with a view to finding a lasting and socially acceptable solution to the cost of subsidies, the authorities elaborated in 1990 the following reform measures:

- improved targeting of vulnerable social groups by the introduction of a qualitative differentia- 
tion of products, with subsidies limited to products mainly consumed by the poor;

- direct income support for the poorest;

- more rapid price adjustments for less essential products;

- modest price adjustments for essential goods, including cereals and edible oils; and

- cost reductions through a more efficient administration of the subsidy scheme.

Under the reforms, a targeting system was introduced for vegetable oil, sugar, milk, and flour; annual price increases were effected; and subsidies on several products were removed, including imported sugar, several kinds of animal feed, various fertilizers, and some cereal derivatives. Responding to these measures, expenditures on subsidies began to decline in 1990 and were equivalent to 1.8 percent of GDP by 1992 .

The authorities intend to extend the scope of price liberalization. At the producer level, apart from subsidized consumer goods and utilities, only a few products remain subject to price control. With the establishment of appropriate competitive conditions following the removal of import restrictions, producer prices of these products will be freed. Similarly, further progress in the liberalization of distribution margins will be linked to the strengthening of competition in the distribution sector and the liberalization of imports.

\section{Public Enterprise Reform}

The public enterprise sector, which played a key role in the growth of the Tunisian economy in the mid-1980s, accounted for a large share-between one fourth and one third-of employment, GDP, and investment. Its reform was viewed as an important element in the overall restructuring of the economy.

Public enterprises had been set up for various purposes, including to exploit natural resources and monopolies, open up new sectors, develop capitalintensive projects, promote regional economic development, and create employment opportunities. In 1985, the public enterprise sector included some five hundred fifty units, consisting of enterprises with marketable products engaged in commercial, industrial, or service activities, as well as various regulatory agencies and offices, which were mainly extensions of the Central Government. During the first half of the 1980s, the overall financial performance of the sector deteriorated, increasing both its indebtedness and its need for budgetary support.

With a view to reducing the burden on the government budget and the absorption of domestic and external financial resources and to improving overall resource allocation in the economy, the Government's 1986 reform effort encompassed the public enterprise sector. The reform aimed at reducing the scope of the public enterprise sector through the transfer of the managerial responsibilities for a large number of enterprises to nongovernment shareholders and through the divestiture of enterprises, either by privatizing those engaged in marketable production in competitive sectors of the economy or by totally or partially liquidating nonviable entities. It also sought to improve the position of enterprises that were to remain under government control by restructuring them and clarifying their relationship to the Government.

A law on public enterprises enacted in early 1989 increased the minimum share of governmentowned equity required for an enterprise to qualify as a public entity from more than 33 percent to more than 50 percent. The number of public enterprises, thus defined, amounted to some two hundred, of which about one hundred fifty produced marketable goods and services. The law also granted more autonomy in management to the enterprises remaining under government control, with the objective of shifting from control of individual decisions to evaluation of performance. This evaluation was to be based on specific enterprise objectives and performance targets set out in performance contracts concluded between the Government and the enterprises concerned.

The three-year performance contracts specified both the obligations of the enterprises in terms of economic, financial, and managerial targets and the Government's obligations in terms of tariff approval, pricing, and other support measures. The contracts were designed to ensure that the financial and technical management of the enterprises could be sustained under quasi-commercial conditions. In addition, programs for the restructuring of specific public enterprises were to be set up to rationalize their operations and investment programs and to reorganize their financial structure. Some of the restructuring operations were to be carried out in the framework of performance contracts or, in other cases, as the initial step in the privatization process. Under the law, the process of divestiture, which had been initiated on an ad hoc basis, was streamlined.

In the first phase, the privatization program was directed mainly at small and medium-size enterprises. Following the sale of enterprises that were relatively sound-such as hotels and factories that produced textiles, mechanical goods, and construction materials- the divestiture would tackle loss-making enterprises. In these cases, divestiture often involved selling a part of an enterprise's 
assets and liquidating other parts. Those sales, in many instances, required that the Government relinquish all or part of its claims on an enterprise and assume certain liabilities. By early 1993, some 40 public enterprises had been privatized, 28 through the sale of assets and the remainder through the sale of equity. Regarding the enterprises that were to remain in the public sector, performance contracts for seven enterprises operating in the transportation, energy, mining, and construction material sectors were in place by the end of 1992.

In addition, a comprehensive study has been prepared for the restructuring of the principal conglomerate in the chemical industry. For the public enterprise sector as a whole, indications are that its economic performance has improved since 1987 despite continuing increases in financial costs. Although the increase in the total indebtedness of the sector has slowed down, the share of its shortterm debt has increased. Both divestiture and privatization took longer than envisaged because the preparatory work turned out to be more complex and time-consuming than originally expected and the mobilization of financial resources proved to be difficult.

In the second phase, initiated in early 1993, the focus has shifted to large profitable enterprises, which will be privatized through the sale of shares. With the elaboration of a comprehensive program and the strengthening of its management, privatization is expected to accelerate considerably. The experience gained in the elaboration of performance contracts is also expected to help speed up the preparation of new contracts.

\section{Liberalization of Investment and Rationalization of Incentives}

Beginning in the 1970s, investment in Tunisia came increasingly under the control of the Government, and, under the Sixth Development Plan (1981-86), some 55 percent of gross fixed capital formation was carried out by the public sector. In addition, with a view to directing investment into specific activities, most private sector investment, including replacement investment and all investment in the industrial sector, was subject to government approval. That policy stance had made most investments eligible for various fiscal and financial incentives, which were provided for under various investment codes, finance laws, and regulations adopted between 1969 and the early 1980s. An important element of the Government's reform program involved liberalizing investment and rationalizing investment incentives starting in 1986.
Under the revised industrial investment code adopted in 1987, the requirement of prior approval for investments that did not seek special incentives was abolished and replaced by a registration obligation, thereby removing an important barrier to investment. Benefits under the new code were made available to replacement investment for the first time as well as to new and extension investments. Benefits were reduced and better targeted and procedures for obtaining them were simplified considerably. In descending order of importance, benefits were extended for investment in export industries, in activities contributing to regional development, and to technology transfer and industrial integration. In subsequent years, the investment codes for agriculture and fishing, as well as for tourism, were updated along the lines of the revised industrial investment code, and codes for service activities, trading companies, and housing were adopted as well, with more extensive incentives provided for export activities.

In general, fiscal incentives included a total or partial exemption from income tax (on a temporary or permanent basis) and registration duties; preferential tax treatment of income from exports; partial or total exemption from tax on reinvested profits; and suspension or repayment of VAT and customs duties. In addition, many investors received financial incentives, such as credits with preferential interest rates, and direct capital grants from the Government for the cost of feasibility studies and of infrastructure.

The multiple special incentives incorporated in the various investment codes and other regulations often overlapped and provided different treatment of economic sectors, resulting in distortions in the allocation of resources among sectors and high budgetary costs. In response to these problems, the Government has decided to elaborate a unified investment code that will harmonize the principal incentives and eliminate those that are directed only at specific sectors or that are no longer justified in light of the reformed income tax system with its favorable treatment of income from capital. The new unified code, which will become effective in 1994, will target the special incentives to clearly defined functional objectives, including the promotion of exports and regional development, the assimilation of new technology, the protection of the environment, and the promotion of new entrepreneurs.

\section{Trade Liberalization}

Since the 1970s, imports have been classified under Tunisia's trade system as either liberalized 
or restricted. Liberalized imports are exempt from prior authorization and can be imported with an import certificate. Items on the restricted list may be imported with an annual import authorization, an import license, or an import card. Under an annual import authorization, certain staples or industrial products may be imported by specific industrialists, agencies, or merchants up to a global annual limit. Import licenses are issued for six months and can be used to import certain consumer and durable goods, while import cards are granted to small-scale firms to cover urgent needs up to annual ceilings.

The Tunisian economy had been controlled on the external front by a high level of import tariffs, with widely dispersed rates, as well as by widespread quantitative import restrictions. Those controls, tightened in 1984-85 when the balance of payments came under serious pressure, intensified the distortions in the allocation of resources and undermined the competitiveness of the economy while biasing production against exports. With a view to strengthening the outward orientation of the economy, Tunisia embarked in 1986 on a major import liberalization program.

The program was expected to reduce costs substantially, thereby promoting export growth, and increase exposure of local industries to foreign competition, which would foster gains in productivity and improvements in product quality. It involved reducing quantitative restrictions gradually and lowering and rationalizing import duties. At the outset of the program, the proportion of imports under the free regime amounted to only about 18 percent of total imports, excluding those financed from external sources. In addition, import duties ranged between 5 percent and 236 percent, with an average tariff rate of 36 percent and a standard deviation of 26 percent.

The Government's original goal was to liberalize by 1991 all imports with the exception of luxury goods while reaching a reasonably uniform effective protection rate of about 25 percent. The liberalization was to be carried out in two stages: in a first stage, covering 1986-88, the lifting of import restrictions was to be directed at imports of raw materials, semifinished products, spare parts, and capital goods; in the second stage, covering 198891 , the liberalization was to be extended to consumer goods. The bulk of the tariff reform, involving the reduction in the maximum tariff and the tariff range, was to be implemented in 1987-88.

During the first phase, certain categories of goods were added to the list of free goods, and other goods were liberalized for certain users, either specific sectors of production, investors, or exporters. Specific measures were introduced to improve the competitiveness of exporters: restrictions on imports of raw materials and semifinished products were lifted for enterprises exporting a minimum share of their turnover, first set at 25 percent and later reduced to 15 percent. Subsequently, the same advantage was extended to all producers up to the value of their exports.

In addition, fiscal advantages were broadened for exporters, including the liberalization of the temporary admission scheme and duty drawback system. Other measures limited to specific users consisted of the removal of quantitative restrictions on the imports of goods required for the maintenance of hospitals and plant and equipment in the agricultural and services sectors (a facility already available to industrial enterprises and hotels); inputs for the pharmaceutical sector; and capital goods for investment projects in the industrial and services sectors, except those for which a domestically produced equivalent existed. As of January 1988, imports of raw materials, spare parts, semifinished products, and capital goods had been liberalized, with the exception of certain goods, most of which were produced by infant industries or imported by other industries that were weakly integrated. Thus, the ratio of imported goods not subject to restrictions rose to 53 percent of total imports.

In the area of tariff reform, the maximum import duty rate was reduced in two steps in $1987-88$, to 36 percent; rates ranging between 21 percent and 35 percent were lowered to 20 percent; and rates of 36 percent and higher were reduced by 15 percentage points. To narrow tariff dispersion, the minimum import duty was raised to 10 percent from 5 percent in 1987. In a move designed to simplify the tax system, the long-standing customs formality tax of 5 percent and the 2 percent special import tax for the promotion of exports introduced in 1985 on certain goods were abolished and integrated with the regular import duties in 1988. Reflecting this measure, tariff rates were adjusted upward by 7 percentage points, with the minimum rate amounting to 17 percent, ${ }^{10}$ the maximum to 43 percent, and the average to about 27 percent.

Following the rapid progress made during the first phase, the pace of liberalization slowed somewhat after 1988 as the authorities sought to strengthen the ability of domestic industries to adjust to increased foreign competition. Quantitative restrictions were lifted in September 1989 and October 1990 for additional categories of goods, including raw materials, intermediate products,

\footnotetext{
${ }^{10}$ For commodities that were exempt from the export promotion tax or from both the export promotion tax and the customs formality tax, the minimum import duty rates amounted to 15 percent and 10 percent, respectively.
} 
capital goods, and consumer goods, raising the ratio of liberalized imports to 70 percent of the total. However, as the liberalization had thus far related primarily to raw materials, capital and intermediate goods, and finished goods not produced locally, only 26 percent of domestic production was subject to import competition by the end of 1990.

Further progress in liberalization was hindered as a result of the sequencing of the reform measures. With a significant reduction in import tariffs already achieved, the removal of quantitative restrictions was to result in a sudden, substantial reduction in the protection of affected industries. In addition, the previous removal of restrictions on imported inputs had increased the effective protection of the production of final goods. In these circumstances, and to allow domestic producers more time to adjust to foreign competition, the Government, in the context of the 1991 finance law, introduced transitional compensatory customs duties with rates ranging between 10 percent and 30 percent for a limited group of finished and semifinished products. These duties were scheduled to be eliminated progressively over three years from the date of their imposition.

In 1992 and 1993 following further rounds of import liberalization, the list of products was extended and most of the rates introduced earlier were reduced. More quantitative restrictions were lifted in 1991-93, bringing the import liberalization ratio to 87 percent and increasing the share of domestic production subject to import competition to some 60 percent. Although the level and structure of import duties were not fundamentally modified, the tariff structure underwent successive rationalizations in order to harmonize levels of effective protection for the various stages of production, with the aim of complementing the removal of quantitative restrictions. In the context of the supplementary budget adopted in March 1991 in the wake of the Middle East crisis, a temporary import surcharge amounting to 5 percent of duties and taxes on imports was introduced to enhance revenue. The surcharge was subsequently extended under the 1992 and 1993 budgets.

The Government plans to continue liberalizing imports until all controls, except those on securityrelated items, are removed. In addition, the authorities will eliminate compensatory duties, and, following the elimination of quantitative restrictions, they intend to lower import tariffs gradually. Tunisia has also started preliminary discussions with the European Community (EC) with a view to creating, over time, a free trade zone between the EC and Tunisia.

\section{Convertibility}

With the move toward a more outward-looking trade policy, Tunisia undertook a number of steps to ease foreign exchange controls. Regarding payments for imported goods, Tunisia has not recently restricted the availability of foreign exchange, but had used trade restrictions to limit the demand for foreign exchange. To the extent that these trade restrictions declined, there was an indirect easing of exchange restrictions and a move toward current account convertibility. Concurrently, Tunisia gradually liberalized payments for invisible transactions by delegating to authorized banks more authority for payments abroad, by increasing exchange allocations for invisible transactions, and by easing regulations on opening foreign exchange or convertible dinar accounts and on using the accounts for making payments abroad. ${ }^{11}$

Exchange allocations for invisible transactions were increased several times during 1986-92. The current settlement allowance for study abroad is equivalent to D 1,000 a year, and the allowance for educational expenses abroad, to D 600 a month. Residents traveling abroad as tourists are entitled once a year to an exchange allocation equivalent to D 500 (D 250 for children under 10 years of age), with the possibility of accumulating allocations for two consecutive years. A business travel allocation is provided to all enterprises. Annual allowances for business travel included in professional accounts and business travel by exporters vary from D 10,000 to D 80,000 depending on the value of export sales. The allocation for importers, based on the applicant's import turnover, varies from D 5,000 to D 30,000 . For entities not involved in importing or exporting, including the liberal professions, the amount of the allocation is based on the volume of business reported to the tax administration and varies from D 2,000 to D 20,000. For new entrepreneurs, an allocation of D 5,000 is provided. However, with effect from January 6, 1993, all bona fide applications for amounts higher than those specified for travel and study abroad are being approved after it is verified that the application is not for the purpose of transferring capital.

The liberalization of the foreign exchange controls on current account transactions- together with the strengthening of macroeconomic policies and the implementation of comprehensive structural reforms, which increased the role of market forces in domestic price formation and resource allocationenabled Tunisia to establish the convertibility of the dinar for current account transactions on January 6, 1993 and to assume the obligations under Arti-

\footnotetext{
"For a comprehensive description of Tunisia's exchange system, see International Monetary Fund (1993).
} 
cle VIII, Sections 2,3, and 4 of the IMF's Articles of Agreement. ${ }^{12}$ In May 1993, a law liberalizing all payments for current account transactions was passed.

With regard to capital account transactions, Tunisian law provides that foreign investors may repatriate in foreign exchange capital invested in liberalized sectors; they may also repatriate the net proceeds from the sale and liquidation of their assets even if these amounts exceed the initial foreign exchange investment and the capital income generated, as long as the company's books are in order. In general, all capital transactions by nonresidents are liberal.

\footnotetext{
${ }^{12}$ Surrender requirements are not considered restrictions within the letter of Article VIII, Section $2(a)$, which prohibits restrictions only on the making of payments and transfers, but not on receipts. Surrender requirements render the currency internally inconvertible only.
}

In contrast, all capital transfers by residents, the extension of loans to nonresidents, and the contraction of foreign loans by residents require the approval of the Central Bank. However, the amortization of foreign debt is automatic. Effective January 1993 , banks are allowed to borrow up to $\$ 10$ million a year from abroad, and firms up to $\$ 3$ million a year, without prior authorization from the Central Bank. Resident businessmen earning foreign exchange are now allowed to invest abroad in connection with their business using funds available in their professional accounts. If they do not keep such accounts, they may obtain foreign exchange from commercial banks. Only commercial banks are informed of these investments. In summary, Tunisia has established currency convertibility for capital account transactions for nonresidents and has taken steps to ease payments restrictions regarding capital transactions by residents. 


\section{Performance}

T he policies Tunisia followed helped to accelerate economic activity, increase gross fixed investment, reduce inflation, strengthen the external sector position, and reduce the external debt and debt-service ratios.

\section{Growth and Its Sources}

Owing to the positive impact of the steady implementation of the program of structural reform and economic adjustment, Tunisia's growth performance improved significantly during 1987-92. ${ }^{13}$ The economy registered an average annual growth rate of 5.0 percent, compared with 2.8 percent during 1982 86 (Table 5). The growth was broadly based, with most of the major sectors of the economy registering higher growth rates of value added in constant prices in 1987-92 than during the previous five years. While the contribution of the agricultural sector, including fishing and food processing, to GDP growth increased from an average of 0.3 percentage point of GDP in 1982-86 to an average of 1.2 percentage points in 1987-92, that of the nonagricultural sectors rose from an average of 2.5 percentage points to an average of 3.8 percentage points over the same period (Table 6). Among the nonagricultural sectors, the service sector recorded the largest increase in the contribution to growth of the sectors: it rose from an average of 1.5 percentage points to an average of 2.3 percentage points, while the contribution to growth in the manufacturing sector increased from an average of 0.6 percentage point to an average of 0.8 percentage point.

Economic performance in 1987-92 continued to be subject to large annual fluctuations, owing to the vulnerability of agricultural output to shifts in weather conditions. In particular, the 1988 drought caused real GDP to stagnate, following an expansion of 6.7 percent in 1987. The return of good weather conditions in 1990 contributed to an accel-

${ }^{13}$ This section analyzes the output performance during 198792; the adjustment measures taken in late 1986 did not immediately affect production. eration in economic activity to 7.6 percent in that year. The outturn in 1991-92 largely reflected the impact of the Middle East crisis on the Tunisian economy and the subsequent recovery. Excluding 1991-92, the range of increase in value added of the nonagricultural sectors as a percentage of GDP narrowed from $0.6-4.2$ in 1982-86 to 3.2-4.1 during subsequent years, indicating a more steady growth of the economy. Moreover, there were shifts in the relative contributions of the various nonagricultural sectors during 1987-90. Although services made the strongest contribution in 1987-88, reflecting the resumption of growth of tourism and the strong expansion of commerce in part related to the reopening of the border with Libya, the strong expansion of the manufacturing sector and of construction and public works in 1989-90 offset the slower growth of the service sector.

There were also some changes in the sectoral composition of total GDP (Table 7). The share of the agricultural sector in GDP rose from 16.4 percent in $1982-86$ to 17.2 percent in 1987-92. This increase resulted from generally more favorable climatic conditions in the later years as well as the impact of measures undertaken to restructure and promote the sector, including the strengthening of extension services, the increase in producer prices, and the expansion of the role of the private sector. The share of the manufacturing sector rose from 9.0 percent of GDP in $1981-86$ to 11.5 percent in 1987-92, mainly on account of the rapid growth of textiles, clothing, and leather. Meanwhile, the increase in the share of services from 43.2 percent to 45.9 percent over the same periods reflected above-average growth rates of all components, in particular, transport, telecommunications, and commerce. Sectors that experienced reductions in their share in total GDP included the mining, construction and public works, and petroleum sectors. The share of the petroleum sector, the only sector that contracted in absolute terms in 1987-92, albeit at a somewhat slower pace than in 1982-86. declined from 9.6 percent to 6.4 percent of GDP between the two periods. 
Table 5. Sectoral Distribution of Real GDP Growth (In percent)

\begin{tabular}{|c|c|c|c|c|c|c|c|c|c|c|c|}
\hline & 1982 & 1983 & 1984 & 1985 & 1986 & 1987 & 1988 & 1989 & 1990 & 1991 & 1992 \\
\hline Agriculture and fishing & -10.3 & 2.5 & 12.9 & 17.3 & -12.2 & 20.5 & -25.8 & 5.7 & 27.7 & 14.7 & 5.8 \\
\hline Mining & -7.1 & 19.3 & -5.3 & -14.0 & 25.3 & 6.8 & 1.0 & 7.2 & -6.7 & 0.1 & -1.1 \\
\hline $\begin{array}{l}\text { Hydrocarbons, electricity, and water } \\
\text { Of which: Hydrocarbons }\end{array}$ & $\begin{array}{l}-3.1 \\
-4.5\end{array}$ & $\begin{array}{l}7.8 \\
7.6\end{array}$ & $\begin{array}{r}0.3 \\
-0.9\end{array}$ & $\begin{array}{l}-0.2 \\
-1.6\end{array}$ & $\begin{array}{l}-1.4 \\
-2.7\end{array}$ & $\begin{array}{l}-3.3 \\
-5.0\end{array}$ & $\begin{array}{l}-0.3 \\
-1.6\end{array}$ & $\begin{array}{l}1.0 \\
0.6\end{array}$ & $\begin{array}{r}5.9 \\
-8.4\end{array}$ & $\begin{array}{l}11.3 \\
13.3\end{array}$ & $\begin{array}{r}0.8 \\
-0.3\end{array}$ \\
\hline $\begin{array}{l}\text { Manufacturing } \\
\text { Food processing } \\
\text { Construction materials and glass } \\
\text { Mechanical and electrical industries } \\
\text { Chemical and rubber industries } \\
\text { Textiles, clothing, and leather } \\
\text { Woodwork, paper, and other }\end{array}$ & $\begin{array}{r}2.8 \\
-7.4 \\
1.3 \\
8.9 \\
6.0 \\
4.0 \\
13.3\end{array}$ & $\begin{array}{r}8.3 \\
3.7 \\
15.6 \\
8.9 \\
12.3 \\
4.3 \\
10.6\end{array}$ & $\begin{array}{r}6.7 \\
18.6 \\
2.1 \\
7.5 \\
-0.3 \\
0.4 \\
9.5\end{array}$ & $\begin{array}{r}5.1 \\
-0.5 \\
10.8 \\
5.5 \\
6.7 \\
4.3 \\
8.3\end{array}$ & $\begin{array}{r}4.8 \\
4.7 \\
1.1 \\
0.4 \\
14.9 \\
5.6 \\
4.2\end{array}$ & $\begin{array}{r}4.4 \\
1.8 \\
4.9 \\
-0.5 \\
8.4 \\
7.6 \\
5.2\end{array}$ & $\begin{array}{r}6.5 \\
4.2 \\
8.0 \\
4.1 \\
12.6 \\
8.0 \\
5.1\end{array}$ & $\begin{array}{r}6.0 \\
-6.1 \\
7.2 \\
7.4 \\
3.8 \\
13.5 \\
7.4\end{array}$ & $\begin{array}{r}11.1 \\
15.0 \\
7.8 \\
9.6 \\
4.6 \\
14.9 \\
6.1\end{array}$ & $\begin{array}{l}4.1 \\
6.3 \\
1.5 \\
3.8 \\
2.9 \\
4.0 \\
4.8\end{array}$ & $\begin{array}{r}8.0 \\
14.4 \\
4.3 \\
3.9 \\
4.8 \\
8.3 \\
7.8\end{array}$ \\
\hline Manufacturing, excluding food processing & 6.1 & 9.5 & 3.5 & 6.9 & 4.8 & 5.2 & 7.2 & 9.3 & 10.2 & 3.5 & 6.5 \\
\hline Construction and public works & 2.1 & -0.6 & 6.1 & -3.1 & -13.2 & -4.8 & -4.6 & 11.9 & 15.3 & 1.0 & 8.6 \\
\hline $\begin{array}{l}\text { Services } \\
\text { Transport and telecommunications } \\
\text { Tourism } \\
\text { Commerce and other services } \\
\text { Government wages and salaries }\end{array}$ & $\begin{array}{r}2.4 \\
0.4 \\
-9.5 \\
3.5 \\
5.2\end{array}$ & $\begin{array}{r}3.8 \\
3.8 \\
-6.8 \\
4.5 \\
5.8\end{array}$ & $\begin{array}{r}5.1 \\
9.6 \\
-0.2 \\
5.6 \\
3.8\end{array}$ & $\begin{array}{r}5.0 \\
4.4 \\
22.3 \\
3.1 \\
4.7\end{array}$ & $\begin{array}{r}1.4 \\
-3.2 \\
-0.7 \\
2.8 \\
1.2\end{array}$ & $\begin{array}{r}6.4 \\
9.8 \\
37.2 \\
3.5 \\
2.5\end{array}$ & $\begin{array}{r}8.0 \\
6.4 \\
11.6 \\
10.2 \\
3.2\end{array}$ & $\begin{array}{r}2.7 \\
5.0 \\
-2.8 \\
2.5 \\
4.0\end{array}$ & $\begin{array}{r}3.3 \\
3.7 \\
-0.8 \\
3.7 \\
3.8\end{array}$ & $\begin{array}{r}-0.0 \\
1.8 \\
-29.6 \\
2.1 \\
4.6\end{array}$ & $\begin{array}{r}10.1 \\
12.5 \\
53.9 \\
7.5 \\
4.2\end{array}$ \\
\hline Indirect taxes minus subsidies & -0.5 & 4.7 & 5.7 & 3.3 & 0.8 & 6.7 & 0.1 & 1.9 & 8.1 & 2.1 & 8.5 \\
\hline GDP (at constant market prices) & -0.5 & 4.7 & 5.8 & 5.2 & -1.1 & 6.7 & 0.1 & 3.7 & 7.6 & 3.9 & 8.0 \\
\hline $\begin{array}{l}\text { GDP (at constant market prices), excluding } \\
\text { agriculture, fishing, and food processing }\end{array}$ & 1.5 & 5.0 & 4.3 & 3.4 & 0.7 & 4.5 & 5.1 & 3.8 & 4.5 & 1.9 & 8.2 \\
\hline
\end{tabular}


Table 6. Sectoral Contribution to Real GDP Growth (In percent)

\begin{tabular}{|c|c|c|c|c|c|c|c|c|c|c|c|}
\hline & 1982 & 1983 & 1984 & 1985 & 1986 & 1987 & 1988 & 1989 & 1990 & 1991 & 1992 \\
\hline Agriculture and fishing & -1.5 & 0.3 & 1.6 & 2.3 & -1.8 & 2.9 & -4.2 & 0.7 & 3.4 & 2.1 & 0.9 \\
\hline Mining & -0.1 & 0.2 & -0.1 & -0.2 & 0.3 & 0.1 & 0.0 & 0.1 & -0.1 & 0.0 & -0.0 \\
\hline Hydrocarbons, electricity, and water & -0.4 & 0.9 & 0.0 & -0.0 & -0.1 & -0.3 & -0.0 & 0.1 & -0.5 & 0.8 & 0.1 \\
\hline Of which: hydrocarbons & -0.4 & 0.7 & -0.1 & -0.1 & -0.2 & -0.4 & -0.1 & 0.0 & -0.6 & 0.8 & -0.0 \\
\hline Manufacturing & 0.4 & 1.1 & 0.9 & 0.7 & 0.6 & 0.6 & 0.9 & 0.9 & 1.6 & 0.6 & 1.2 \\
\hline Food processing & -0.2 & 0.1 & 0.5 & -0.0 & 0.1 & 0.1 & 0.1 & -0.2 & 0.4 & 0.2 & 0.4 \\
\hline Construction materials and glass & 0.0 & 0.3 & 0.0 & 0.2 & 0.0 & 0.1 & 0.2 & 0.2 & 0.2 & 0.0 & 0.1 \\
\hline Mechanical and electrical industries & 0.1 & 0.2 & 0.1 & 0.1 & 0.0 & -0.0 & 0.1 & 0.1 & 0.2 & 0.1 & 0.1 \\
\hline Chemical and rubber industries & 0.1 & 0.2 & -0.0 & 0.1 & 0.2 & 0.1 & 0.1 & 0.0 & 0.0 & 0.0 & 0.0 \\
\hline Textiles, clothing, and leather & 0.1 & 0.1 & 0.0 & 0.1 & 0.2 & 0.3 & 0.3 & 0.5 & 0.7 & 0.2 & 0.4 \\
\hline Woodwork, paper, and other & 0.2 & 0.2 & 0.2 & 0.2 & 0.1 & 0.1 & 0.1 & 0.2 & 0.1 & 0.1 & 0.2 \\
\hline Manufacturing, excluding food processing & 0.6 & 1.0 & 0.4 & 0.7 & 0.5 & 0.5 & 0.7 & 1.0 & 1.2 & 0.4 & 0.8 \\
\hline Construction and public works & 0.1 & -0.0 & 0.4 & -0.2 & -0.8 & -0.2 & -0.2 & 0.5 & 0.7 & 0.1 & 0.4 \\
\hline Services & 1.0 & 1.6 & 2.2 & 2.1 & 0.6 & 2.9 & 3.6 & 1.3 & 1.6 & -0.0 & 4.5 \\
\hline Transport and telecommunications & 0.0 & 0.2 & 0.4 & 0.2 & -0.2 & 0.6 & 0.4 & 0.3 & 0.2 & 0.1 & 0.7 \\
\hline Tourism & -0.4 & -0.2 & -0.0 & 0.7 & -0.0 & 1.2 & 0.5 & -0.1 & -0.0 & -1.2 & 1.4 \\
\hline Commerce and other services & 0.8 & 1.0 & 1.3 & 0.7 & 0.6 & 0.8 & 2.3 & 0.6 & 0.9 & 0.5 & 1.8 \\
\hline Government wages and salaries & 0.6 & 0.7 & 0.4 & 0.5 & 0.1 & 0.3 & 0.4 & 0.5 & 0.5 & 0.5 & 0.5 \\
\hline Indirect taxes minus subsidies & -0.1 & 0.6 & 0.7 & 0.4 & 0.1 & 0.8 & 0.0 & 0.2 & 0.9 & 0.2 & 1.0 \\
\hline GDP (at constant market prices) & -0.5 & 4.7 & 5.7 & 5.2 & -1.1 & 6.7 & 0.1 & 3.7 & 7.6 & 3.9 & 8.0 \\
\hline $\begin{array}{l}\text { GDP (at constant market prices), excluding } \\
\text { agriculture, fishing, and food processing }\end{array}$ & 1.2 & 4.2 & 3.6 & 2.9 & 0.6 & 3.7 & 4.1 & 3.2 & 3.8 & 1.6 & 6.6 \\
\hline
\end{tabular}

Source: Ministry of Planning and Regional Development. 
Table 7. Value Added of Major Economic Sectors (In percent of GDP ot current prices)

\begin{tabular}{|c|c|c|c|c|c|c|c|c|c|c|c|c|}
\hline & 1981 & 1982 & 1983 & 1984 & 1985 & 1986 & 1987 & 1988 & 1989 & 1990 & 1991 & 1992 \\
\hline Agriculture and fishing & 13.7 & 13.2 & 12.2 & 13.8 & 15.2 & 13.3 & 15.3 & 11.7 & 12.1 & 14.4 & 15.8 & 15.6 \\
\hline Mining & 1.6 & 1.1 & 1.2 & I.I & 0.6 & 0.8 & 0.7 & 1.0 & 1.3 & 0.8 & 0.7 & 0.6 \\
\hline Hydrocarbons, electricity, and water & 12.3 & 11.9 & 11.4 & 11.2 & 11.2 & 9.2 & 9.3 & 8.8 & 8.7 & 7.5 & 7.1 & 6.5 \\
\hline Of which: Hydrocarbons & 10.8 & 10.5 & 9.9 & 9.6 & 9.6 & 7.4 & 7.6 & 7.1 & 7.1 & 6.0 & 5.6 & 5.1 \\
\hline Manufacturing & 11.9 & 11.1 & 11.2 & 11.8 & 11.9 & 13.1 & 13.1 & 13.9 & 14.4 & 14.9 & 15.1 & 15.0 \\
\hline Food processing & 3.0 & 2.7 & 2.4 & 2.9 & 2.8 & 3.1 & 2.9 & 3.0 & 2.7 & 2.9 & 3.0 & 3.2 \\
\hline Construction materials and glass & 1.8 & 1.5 & 1.8 & 2.0 & 2.1 & 2.2 & 2.1 & 2.2 & 2.3 & 2.2 & 2.2 & 2.1 \\
\hline Mechanical and electrical industries & 1.6 & 1.7 & 1.7 & 1.7 & 1.8 & 1.9 & 1.8 & 1.9 & 2.0 & 2.0 & 2.1 & 1.9 \\
\hline Chemical and rubber industries & I.1 & 0.8 & 0.7 & 0.7 & 0.6 & 0.6 & 0.7 & 1.0 & 1.0 & 0.9 & 0.9 & 0.8 \\
\hline Textiles, clothing, and leather & 2.9 & 2.9 & 3.0 & 2.7 & 2.8 & 3.4 & 3.6 & 3.8 & 4.3 & 4.7 & 4.7 & 4.8 \\
\hline Woodwork, paper, and other & 1.4 & 1.5 & 1.6 & 1.7 & 1.8 & 2.0 & 2.0 & 2.0 & 2.1 & 2.1 & 2.1 & 2.2 \\
\hline Manufacturing, excluding food processing & 8.8 & 8.4 & 8.8 & 8.9 & 9.1 & 10.0 & 10.2 & 11.0 & 11.6 & 12.0 & 12.1 & 11.8 \\
\hline Construction and public works & 6.3 & 6.9 & 6.7 & 6.5 & 5.9 & 5.4 & 4.6 & 4.4 & 4.6 & 4.9 & 4.8 & 4.9 \\
\hline Services & 41.8 & 43.8 & 43.8 & 42.5 & 42.6 & 44.9 & 44.2 & 47.6 & 47.7 & 45.9 & 44.5 & 45.2 \\
\hline Transport and telecommunications & 4.6 & 4.6 & 5.0 & 5.2 & 5.2 & 5.4 & 5.9 & 6.6 & 6.4 & 6.1 & 5.9 & 6.2 \\
\hline Tourism & 3.9 & 3.8 & 3.9 & 3.2 & 3.3 & 3.0 & 3.9 & 4.3 & 4.2 & 3.9 & 2.7 & 3.6 \\
\hline Commerce and other services & 22.6 & 23.5 & 22.7 & 22.4 & 22.4 & 24.1 & 22.8 & 24.9 & 24.7 & 24.0 & 23.6 & 19.1 \\
\hline Government services & 10.8 & 11.9 & 12.3 & 11.7 & 11.7 & 12.4 & 11.8 & 11.8 & 12.4 & 11.9 & 12.3 & 12.0 \\
\hline
\end{tabular}

Source: Ministry of Planning and Regional Development. 


\section{Investment and Savings}

The high ratio of investment to GDP recorded in the early 1980 s declined to a more sustainable level under the adjustment programs (Chart 6 and Table 8). This decline reflected a contraction in gross fixed investment by the non-Central Government, in particular, by public enterprises. The gross fixed investment by the non-Central Government fell steadily from 26.2 percent of GDP in 1981 to 14.2 percent in 1988 . Subsequently, the declining trend was reversed, with private sector investment responding positively to the improvements in the macroeconomic environment and the incentive structure, and with some public enterprises expanding capital investment with the easing of foreign exchange constraints. After a temporary slowdown in investment at the onset of the Middle East crisis, the investment-to-GDP ratio of the nongovernment sector again rose, amounting to 21.1 percent in 1992. Meanwhile, the investmentto-GDP ratio of the Central Government, showing no particular trend, fluctuated around 5 percent as in the first half of the 1980s. During the same period, the efficiency of investment in the economy improved as distortions in the structure of relative prices were reduced and the quality of the Government's investment program improved. Mirroring these developments, the incremental capital output ratio exhibited a declining trend after 1987.

The savings performance of the economy improved during 1986-92. Gross domestic savings as a ratio of GDP increased from 16.2 percent in 1986 to 20.4 percent in 1992 , but the average ratio during this period was about 2 percentage points lower than during the first half of the 1980 s, mainly because of lower petroleum revenues. The increasing trend of domestic savings during 1986-92 reflected a dramatic improvement in the savings performance of the non-central government sector, which rose from 5.9 percent of GDP in 1986 to 14.7 percent in 1992 , following the steady implementation of macroeconomic and structural adjustment measures. This improvement was more or less continuous, despite the tendency of private sector savings to change from year to year so as to cushion private consumption levels from the fluctuations in private disposable income caused by swings in agricultural output and movements in the external terms of trade.

In contrast, the savings performance of the Government did not improve during 1986-92 for a number of reasons. First, nontax revenue as a percentage of GDP declined significantly as petroleum revenues dropped. Second, with the reduction and the rationalization of import tariffs under structural reforms, taxes on foreign trade did not grow
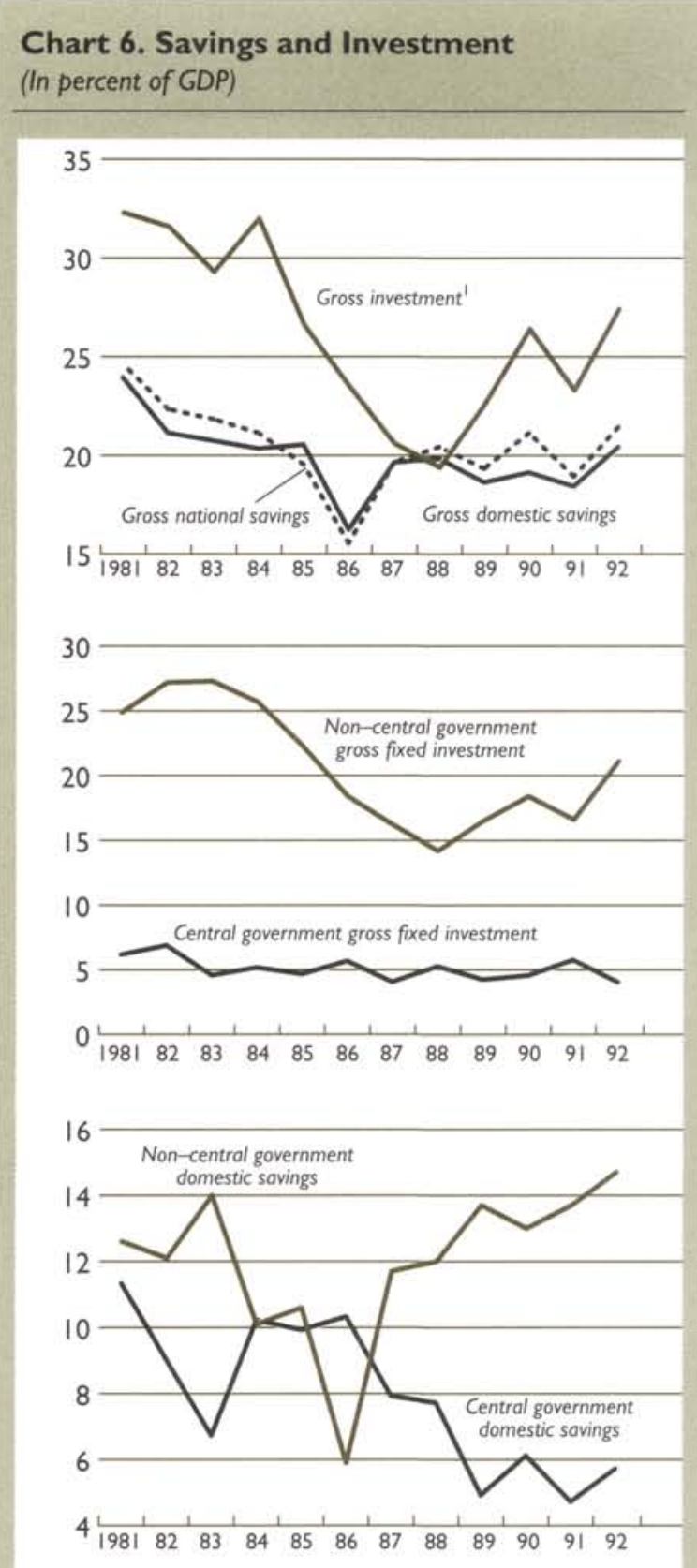

Source: Tunisian authorities; and IMF staff estimates.

Gross fixed investment plus changes in stocks.

in line with imports. Third, fiscal adjustment proved difficult in 1988 and 1989 because the two years of drought and high world cereal prices caused a bulge in consumer subsidy expenditure. Fourth, the Middle East crisis had an unfavorable impact on the economy and hence on the savings performance of the Government in 1991. Finally, interest payments on domestic debt rose as the Government 


\begin{tabular}{|c|c|c|c|c|c|c|c|c|c|c|c|c|}
\hline & 1981 & 1982 & 1983 & 1984 & 1985 & 1986 & 1987 & 1988 & 1989 & 1990 & 1991 & 1992 \\
\hline Consumption & 76.1 & 78.9 & 79.3 & 79.7 & 79.5 & 83.8 & 80.4 & 80.2 & 81.4 & 80.9 & 81.6 & 79.6 \\
\hline Central Government & 13.1 & 14.2 & 16.1 & 13.9 & 13.2 & 13.2 & 12.4 & 11.5 & 12.0 & 11.3 & 11.8 & 11.4 \\
\hline Non-Central Government & 63.1 & 64.7 & 63.3 & 65.8 & 66.4 & 70.6 & 68.0 & 68.7 & 69.4 & 69.5 & 69.7 & 68.2 \\
\hline Gross domestic savings & 23.9 & 21.1 & 20.7 & 20.3 & 20.5 & 16.2 & 19.6 & 19.8 & 18.6 & 19.1 & 18.4 & 20.4 \\
\hline Central Government & 11.3 & 9.0 & 6.7 & 10.2 & 9.9 & 10.3 & 7.9 & 7.7 & 4.9 & 6.1 & 4.7 & 5.7 \\
\hline Non-Central Government & 12.6 & 12.1 & 14.0 & 10.1 & 10.6 & 5.9 & 11.7 & 12.0 & 13.7 & 13.0 & 13.7 & 14.7 \\
\hline Net income from abroad & 0.8 & 1.1 & 1.2 & 0.8 & -1.0 & -0.7 & - & 0.6 & 0.7 & 1.9 & 0.4 & 1.0 \\
\hline Central Government & -1.2 & -1.5 & -1.6 & -1.9 & -2.2 & -2.5 & -2.3 & -2.4 & -2.1 & -2.1 & -2.1 & -1.7 \\
\hline Non-Central Government & 2.0 & 2.6 & 2.8 & 2.7 & 1.2 & 1.8 & 2.3 & 3.0 & 2.8 & 4.0 & 2.5 & 2.7 \\
\hline Gross national savings & 24.6 & 22.2 & 21.8 & 21.1 & 19.5 & 15.5 & 19.6 & 20.4 & 19.3 & 21.1 & 18.9 & 21.4 \\
\hline Central Government & 10.1 & 7.5 & 5.0 & 8.2 & 7.7 & 7.8 & 5.6 & 5.3 & 2.8 & 4.0 & 2.6 & 3.9 \\
\hline Non-Central Government & 14.6 & 14.7 & 16.8 & 12.8 & 11.8 & 7.7 & 14.0 & 15.0 & 16.6 & 17.0 & 16.2 & 17.5 \\
\hline Investment & 32.3 & 31.6 & 29.3 & 32.0 & 26.6 & 23.5 & 20.6 & 19.4 & 22.6 & 26.4 & 23.3 & 27.3 \\
\hline Gross fixed capital formation & 31.0 & 34.0 & 31.8 & 30.8 & 26.8 & 24.0 & 20.3 & 19.3 & 20.7 & 22.9 & 22.4 & 25.1 \\
\hline Changes in stocks & 1.3 & -2.4 & -2.5 & 1.2 & -0.2 & -0.5 & 0.3 & 0.1 & 1.9 & 3.5 & 0.9 & 2.3 \\
\hline Central Government & 6.1 & 6.8 & 4.5 & 5.1 & 4.6 & 5.6 & 4.0 & 5.2 & 4.2 & 4.5 & 5.7 & 4.0 \\
\hline Non-Central Government & 26.2 & 24.8 & 24.8 & 26.9 & 22.1 & 17.9 & 16.6 & 14.2 & 18.4 & 21.8 & 17.5 & 23.3 \\
\hline Of which: Gross fixed capital formation & 24.9 & 27.2 & 27.3 & 25.7 & 22.3 & 18.4 & 16.2 & 14.2 & 16.5 & 18.4 & 16.6 & 21.1 \\
\hline Savings-investment gap & -7.7 & -9.4 & -7.4 & -10.9 & -7.1 & -8.0 & -1.0 & 1.0 & -3.3 & -5.3 & -4.4 & -6.0 \\
\hline Central Government & 4.0 & 0.7 & 0.5 & 3.1 & 3.1 & 2.2 & 1.6 & 0.1 & -1.4 & -0.5 & -3.1 & -0.1 \\
\hline Non-Central Government & -11.7 & -10.1 & -8.0 & -14.0 & -10.3 & -10.2 & -2.6 & 0.8 & -1.8 & -4.8 & -1.3 & -5.9 \\
\hline Exports of goods and nonfactor services & 41.4 & 36.9 & 35.4 & 33.9 & 32.7 & 30.8 & 35.0 & 41.9 & 44.0 & 41.8 & 38.6 & 38.0 \\
\hline Imports of goods and nonfactor services & 49.8 & 47.4 & 44.0 & 45.5 & 38.8 & 38.0 & 36.0 & 41.5 & 48.0 & 49.0 & 43.5 & 45.0 \\
\hline Resource gap & -8.5 & -10.5 & -8.6 & -11.7 & -6.1 & -7.3 & -1.0 & 0.4 & -3.9 & -7.2 & -4.8 & -7.0 \\
\hline Net income from abroad & 0.8 & 1.1 & 1.2 & 0.8 & -1.0 & -0.7 & $\overline{10}$ & 0.6 & 0.7 & 1.9 & 0.4 & 1.0 \\
\hline Current account balance & -7.7 & -9.4 & -7.4 & -10.9 & -7.1 & -8.0 & -1.0 & 1.0 & -3.3 & -5.3 & -4.4 & -6.0 \\
\hline \multicolumn{13}{|l|}{ Memorandum item: } \\
\hline Government capital transfers and net lending & 6.6 & 6.3 & 8.9 & 9.2 & 7.8 & 6.8 & 5.9 & 4.9 & 4.0 & 3.9 & 2.5 & 2.8 \\
\hline
\end{tabular}


Table 9. Price Developments

(Annual percent changes)

\begin{tabular}{|c|c|c|c|c|c|c|c|c|c|c|c|c|}
\hline & 1981 & 1982 & 1983 & 1984 & 1985 & 1986 & 1987 & 1988 & 1989 & 1990 & 1991 & 1992 \\
\hline GDP deflator & 11.2 & 16.0 & 9.3 & 7.3 & 4.9 & 2.6 & 6.7 & 8.5 & 7.2 & 5.7 & 6.8 & 5.8 \\
\hline Consumer price index (CPI) & 8.9 & 13.7 & 9.0 & 8.6 & 7.6 & 6.2 & 8.2 & 7.2 & 7.7 & 6.5 & 7.8 & 5.5 \\
\hline Domestic component of $\mathrm{CPI}$ & $\ldots$ & 16.9 & 8.7 & 7.4 & 7.2 & 7.7 & 6.9 & 6.9 & 6.2 & 6.5 & 8.0 & 6.7 \\
\hline Import prices & $\ldots$ & 3.9 & 10.1 & 12.8 & 8.6 & 1.2 & 12.7 & 7.9 & 12.6 & 6.7 & 7.1 & 2.0 \\
\hline Trading partners' CPIs' & 12.7 & 11.0 & 8.8 & 7.5 & 6.2 & 3.6 & 3.3 & 3.6 & 4.8 & 4.8 & 4.7 & 3.9 \\
\hline
\end{tabular}

Sources: Tunisian authorities; and IMF staff estimates.

'Weighted by non-oil trade and tourism flows of 16 partner and competitor countries.

shifted increasingly to nonbank financing at marketrelated rates.

The improvement in national savings was more significant than that in domestic savings and amounted to 4.9 percentage points of GDP between 1986 and 1992. This reflected, in part, large inflows of private transfers in response to strong incentives provided by the exchange rate adjustments and high real positive interest rates in Tunisia. The decline in the ratio of external interest payments to GDP resulting from the Government's prudent external debt-management policies and the general decline in interest rates in international financial markets also contributed to the improvement.

The savings-investment balance of the Central Government registered declining surpluses in $1986-88$ followed by deficits in $1989-92$. However, in the consolidated financial operations of the Central Government, capital transfers and net lending, which declined continuously from 6.8 percent of GDP in 1986 to 2.8 percent in 1992 , had a significant, positive impact on the overall budgetary position. The savings-investment gap of the noncentral government sector during the adjustment programs, although much lower than in the first half of the 1980s, remained in deficit, except in 1988 , and fluctuated widely. With the continuous improvement in its savings performance, the fluctuations in its savings-investment gap were largely caused by developments in investment by private and public enterprises.

\section{Inflation}

Tunisia's inflation performance was more favorable during 1986-92. The inflation rate, as measured by the consumer price index (CPI), declined from an average of 9.6 percent a year during the first half of the 1980 s to 7.0 percent a year during 1986-92 (Table 9). Although somewhat higher than the average annual inflation rate of 4.1 percent in Tunisia's trading partners during 1986-92, this rate compared favorably with the average annual rate of 55 percent in developing countries during 1986-91.

The amelioration reflected the serious attention given by the authorities to controlling inflation and was achieved notwithstanding a number of adverse developments:

- the adverse impact of droughts on the supply side in 1986, 1988, and 1989;

- the sharp depreciation of the nominal effective exchange rate of the dinar, in particular in 1986-87;

- the reduction in consumer subsidies; and

- the substantial liberalization of domestic prices (products with liberalized prices increased from 5 percent of total production at the end of 1985 to 87 percent at the end of 1992).

The prudent financial policies pursued by the authorities and the liberalization of imports were crucial in mitigating the impact of these factors on prices.

The average annual change in the CPI during 1986-92 fluctuated between 6.2 percent and 8.2 percent before declining to 5.5 percent in 1992 . An analysis of these developments leads to the following observations. First, the annual percentage change in the import component of the CPI fluctuated more than that in the domestic component. Since 1987, the first full program year, the increases in the domestic component of the CPI have remained within the range of 6-7 percent, except in 1991, when excise taxes and some tariffs for public utilities were increased, consumer subsidies were reduced, imports were cut back to mitigate the 


\section{Chart 7. External Economic Indicators}
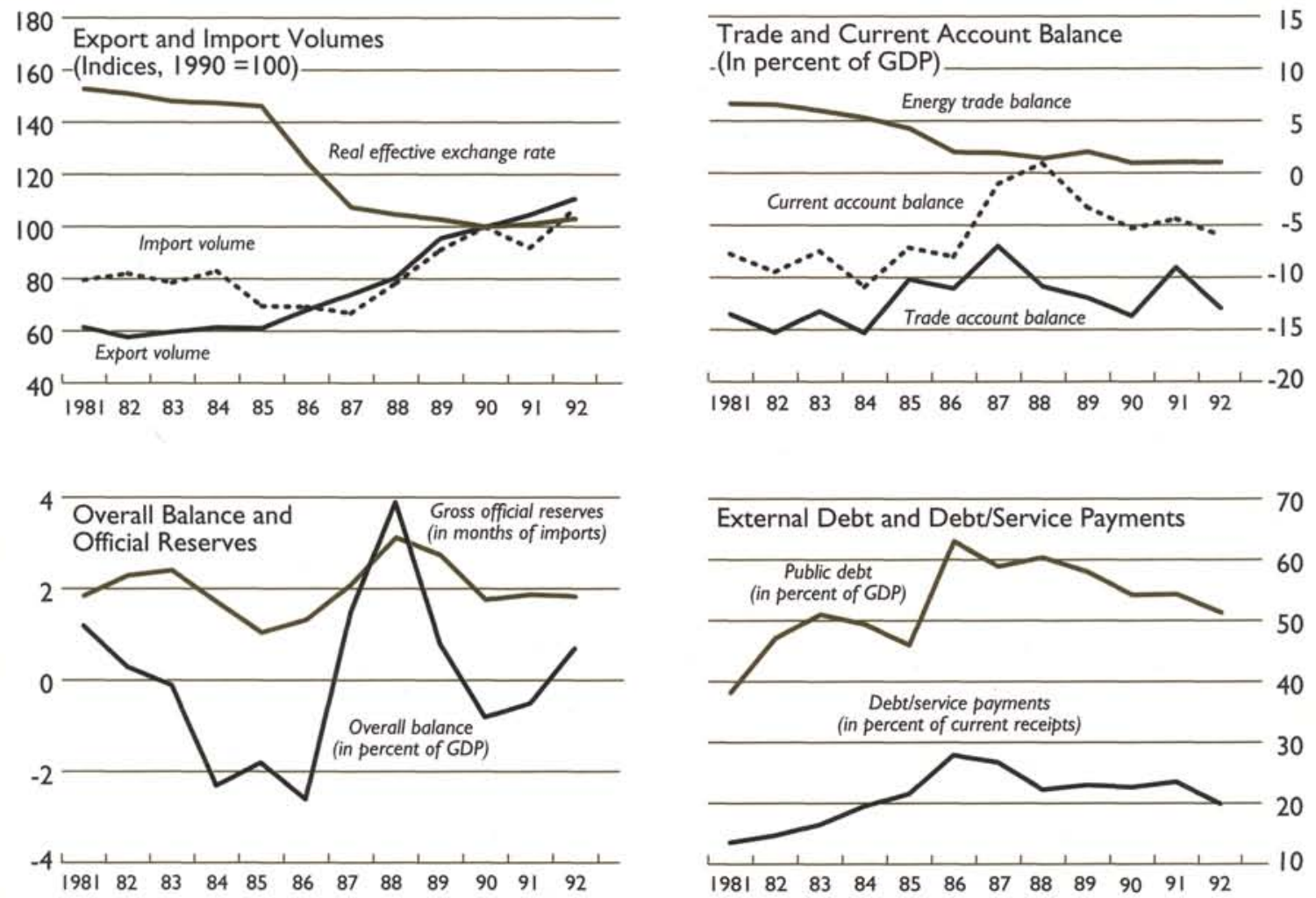

Source: Tunisian authorities; and IMF staff estimates.

impact of the Middle East crisis, and wages and salaries were raised significantly. ${ }^{14}$ Second, the increases in the domestic component of the CPI were higher than the import component only in three years: in 1991, because of the events described above, and in 1986 and 1992, because of sharp decelerations in import price increases. Finally, in the years when inflation decelerated in Tunisia (1986, 1988, 1990, and 1992), import price increases also slowed significantly.

In 1992, inflationary pressures eased substantially owing to the liberalization of the economy, the relatively stable import prices, the favorable supply conditions associated with agricultural production, and the authorities' continued prudent

\footnotetext{
${ }^{14}$ The unit labor cost in the nonagricultural sector, after having increased by only 14.5 percent during $1987-90$, rose by 10.0 percent in 1991.
}

financial policies. Consequently, the rate of price increases slowed down during the course of the year, and, by the end of 1992 , the inflation rate dropped to 5 percent, the lowest level achieved in the past 15 years.

\section{Balance of Payments}

During the first half of the 1980s, Tunisia suffered a serious deterioration in its terms of trade and a sharp decline in petroleum exports owing to adverse price and volume developments (Charts 7 and 8; and Table 10). The emerging large current account deficits, which averaged 8.5 percent of GDP during 1981-85 and reached a peak of 10.9 percent of GDP in 1984, were accompanied by increased borrowing at high interest rates. The rising level of external debt, combined with declining 


\section{Chart 8. Trade Performance}
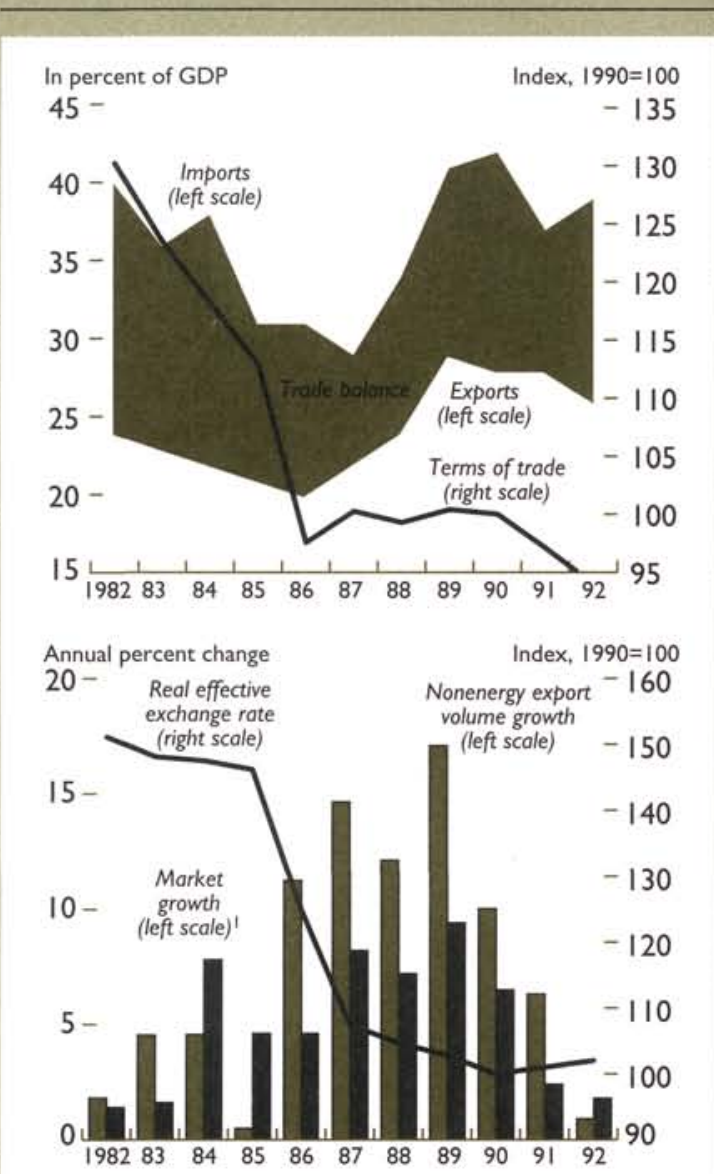

Sources: Tunisian authorities; and IMF staff estimates.

Non/oil import volume growth of main trading partners, weighted by Tunisia's export share in each market. export earnings, led to a doubling in the debtservice ratio between 1981 and 1986 .

The balance of payments position strengthened during 1986-92, with the current account deficit declining to an average of 3.9 percent of GDP during this period owing to the implementation of the wide-ranging structural reforms and prudent demand-management policies described in earlier sections and to a flexible exchange rate policy. Successive exchange rate adjustments translated into a real effective depreciation of the Tunisian dinar by 26.5 percent during $1986-87$, substantially increasing Tunisia's competitiveness. Such an increase in competitiveness at the beginning of the program period, together with the liberalization of the trade system, was critical for strengthening economic incentives and reducing external imbalances. Sub- sequently, the nominal effective exchange rate of the dinar continued to decline during 1988-91. Because this decline more or less compensated for the differential between the inflation rates in Tunisia and in its trading partners, the real effective exchange rate of the dinar remained relatively stable, preventing erosion of Tunisia's competitive position. During 1986-92, the 29.5 percent reduction in the real effective exchange rate of the dinar exceeded the 15.7 percent cumulative fall in Tunisia's terms of trade.

The annual performance of the balance of payments was also affected by the authorities' policy stance. The comprehensive measures adopted in 1986 and 1987, including a tightened credit stance and a sharp drop in the real effective exchange rate combined with an excellent agricultural crop and a rebound in petroleum prices, contributed to a remarkable turnaround in the balance of payments. The current account deficit fell from 8 percent of GDP in 1986 to 1 percent in 1987, and the overall balance of payments position moved from a deficit to a surplus of SDR 110 million ( $\$ 160$ million). In 1988 , the current account moved to an unprecedented surplus of 1 percent of GDP, owing, in part, to the near doubling of tourism receipts occasioned by the opening of the border with Libya in April 1988. Thus, gross reserves reached the equivalent of more than three months of imports by the end of 1988.

In 1989, import volume, driven by a recovery in private sector investment and consumption, picked up sharply and tourism receipts declined. In these circumstances, despite a record growth in the volume of exports, especially those of manufactured goods and energy, Tunisia's current account position weakened. In 1990, a strong growth in imports of capital goods continued, with a boom in investment expenditure by private and public enterprises. The impact of the demand pressures on the current account deficit was also compounded in the second half of that year by the Middle East crisis, which had a detrimental effect on export volumes and receipts from tourism. As a result, the current account deficit widened to 5.3 percent of GDP, and gross reserves declined to 1.8 months of imports by the end of 1990.

The Middle East crisis led to a substantial slowdown in export growth in 1991, because goods previously exported to the Middle East could not be redirected to other markets, and to declines in receipts from tourism and workers' remittances. To alleviate the impact of these developments, the authorities significantly cut back the public enterprises' plans for investments with high import content. Meanwhile, private sector import demand was constrained by tight monetary policy and tempo- 
Table 10. External Sector Indicators

\begin{tabular}{|c|c|c|c|c|c|c|c|c|c|c|c|c|}
\hline & 1981 & 1982 & 1983 & 1984 & 1985 & 1986 & 1987 & 1988 & 1989 & 1990 & 1991 & 1992 \\
\hline & \multicolumn{12}{|c|}{ (Annual percent changes) } \\
\hline Exports, f.o.b. (in SDRs) & $\ldots$ & -13.8 & -3.0 & 1.2 & -3.1 & -11.5 & 9.7 & 7.9 & 28.2 & 13.4 & 4.6 & 5.6 \\
\hline Imports, f.o.b. (in SDRs) & $\ldots$ & -4.2 & -6.1 & 8.0 & -14.4 & -7.6 & -7.2 & 19.7 & 24.4 & 19.1 & -7.0 & 16.9 \\
\hline Export volume & $\ldots$ & -6.1 & 3.4 & 2.9 & -0.7 & 11.3 & 8.9 & 8.7 & 18.8 & 4.5 & 4.7 & 5.8 \\
\hline Of which: Nonenergy & ... & 1.8 & 4.5 & 4.5 & 0.5 & 11.2 & 14.6 & 12.1 & 17.1 & 10.0 & 6.3 & 0.9 \\
\hline Import volume & $\ldots$ & 3.2 & -4.4 & 5.7 & -16.2 & -0.4 & -3.4 & 17.0 & 16.4 & 9.6 & -7.9 & 16.2 \\
\hline Of which: Nonenergy & ... & 9.8 & -4.9 & 5.6 & -17.6 & -1.1 & -5.9 & 20.5 & 14.6 & 10.7 & -7.4 & 15.7 \\
\hline Terms of trade $((-)$ deterioration) & $\ldots$ & -1.1 & -5.1 & -4.3 & -4.4 & -13.6 & 2.8 & -1.0 & 1.1 & -0.4 & -1.0 & -3.6 \\
\hline Nominal effective exchange rate' & 2.3 & -3.4 & -2.2 & -1.3 & -2.6 & -16.2 & -17.2 & -5.2 & -4.2 & -4.6 & -2.3 & 0.6 \\
\hline \multirow[t]{2}{*}{ Real effective exchange rate } & -1.1 & -1.1 & -2.0 & -0.4 & -0.9 & -14.5 & -14.0 & -2.6 & -1.8 & -2.7 & 1.0 & 2.0 \\
\hline & \multicolumn{12}{|c|}{ (Ratios; in percent) } \\
\hline Trade balance/GDP & -13.5 & -15.3 & -13.2 & -15.3 & -10.2 & -11.1 & -7.0 & -10.8 & -11.9 & -13.7 & -9.0 & -12.9 \\
\hline Current account balance/GDP & -7.7 & -9.4 & -7.4 & -10.9 & -7.1 & -8.0 & -1.0 & 1.0 & -3.3 & -5.3 & -4.4 & -6.0 \\
\hline External debu/GDP & 38.2 & 47.1 & 51.0 & 49.4 & 46.0 & 63.0 & 58.9 & 60.4 & 58.0 & 54.2 & 54.3 & 51.4 \\
\hline Debt service/current receipts ${ }^{2}$ & 13.6 & 14.7 & 16.5 & 19.5 & 21.6 & 27.9 & 26.8 & 22.3 & 23.0 & 22.7 & 23.5 & 19.9 \\
\hline \multirow{3}{*}{$\begin{array}{l}\text { Gross official international } \\
\text { reserves (in months of imports) }\end{array}$} & & & & & & & & & & & & \\
\hline & 1.8 & 2.3 & 2.4 & 1.7 & 1.0 & 1.3 & 2.1 & 3.1 & 2.7 & 1.8 & 1.9 & 1.8 \\
\hline & \multicolumn{12}{|c|}{ (In millions of SDRs) } \\
\hline $\begin{array}{l}\text { Overall balance of payment } \\
\text { surplus or deficit }(-)\end{array}$ & 83 & 25 & -11 & -183 & -147 & -195 & 110 & 295 & 62 & -74 & -48 & 83 \\
\hline \multicolumn{13}{|l|}{ Gross official international } \\
\hline reserves (at end of period) & 467 & 556 & 548 & 422 & 219 & 257 & 378 & 676 & 739 & 565 & 559 & 658 \\
\hline External debt (at end of period) & 2,804 & 3,124 & 3,454 & 3,858 & 3,974 & 4,305 & 4,267 & 4,336 & 4,713 & 5,007 & 5,355 & 5,478 \\
\hline
\end{tabular}

Sources: Tunisian authorities; and IMF staff estimates.

Weighted by non

${ }^{2}$ Debt service includes repurchases from the IMF. 


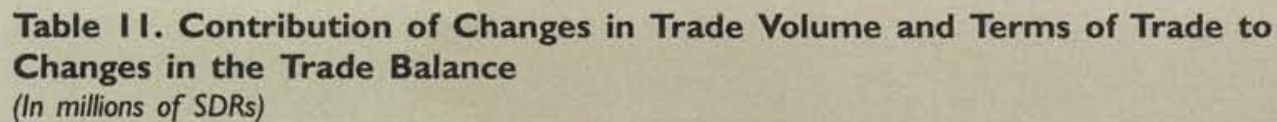

\begin{tabular}{|c|c|c|c|c|c|c|c|}
\hline & \multirow[b]{2}{*}{$\begin{array}{c}\text { Trade } \\
\text { Balance }\end{array}$} & \multirow{2}{*}{$\begin{array}{l}\text { Changes } \\
\text { in Trade } \\
\text { Balance } \\
\text { (actual) }\end{array}$} & \multirow{2}{*}{$\begin{array}{l}\text { Changes } \\
\text { in Trade } \\
\text { Balance } \\
\text { (calculated)' }\end{array}$} & \multicolumn{4}{|c|}{ Contributions of } \\
\hline & & & & $\begin{array}{l}\text { Net export } \\
\text { volume }\end{array}$ & $\begin{array}{l}\text { Export } \\
\text { volume }\end{array}$ & $\begin{array}{l}\text { Import } \\
\text { volume }\end{array}$ & $\begin{array}{c}\text { Terms of } \\
\text { trade }\end{array}$ \\
\hline 1986 & -833.0 & -4.4 & 54.9 & 204.1 & 192.9 & 11.2 & -149.2 \\
\hline 1987 & -519.6 & 313.4 & 271.9 & 213.3 & 133.7 & 79.6 & 58.7 \\
\hline 1988 & -815.6 & -296.0 & -242.5 & -225.9 & 143.3 & -369.2 & -16.6 \\
\hline 1989 & -947.4 & -131.8 & -123.3 & -90.0 & 335.2 & -425.2 & -33.3 \\
\hline 1990 & $-1,260.1$ & -312.7 & -303.2 & -207.8 & 102.7 & -310.5 & -95.4 \\
\hline 1991 & -869.9 & 390.2 & 388.5 & 425.8 & 122.4 & 303.4 & -37.3 \\
\hline 1992 & $-1,445.7$ & -575.8 & -555.4 & -422.2 & 157.5 & -579.7 & -133.2 \\
\hline Cumulative & $-6,691.3$ & -617.1 & -509.0 & -102.7 & $1,187.7$ & $-1,290.4$ & -406.3 \\
\hline
\end{tabular}

Sources: Tunisian authorities; and IMF staff estimates.

'The following equation was used to decompose the changes in Tunisia's trade balance:

$d T B=X \dot{x}-M \dot{m}+\left(X \dot{p}_{x}-M \dot{p}_{m}\right)$.

where: $\quad d T B=$ total change in the trade balance

$X=$ nominal exports in the base year

$\dot{x}=$ rate of change in export volume

$M=$ nominal imports in the base year

$\dot{m}=$ rate of change in import volume

$\dot{p}_{x}=$ rate of change in export unit value

$\ddot{p}_{m}=$ rate of change in import unit value

The first term on the right-hand side approximates the export volume effect, the second term the import volume effect, and the third term the terms of trade effect. This equation gives rise to unexplained residuals, particularly in years when the changes in the variables were large, insofar as the equation involves a linear approximation.

rary administrative measures, with authorization for the importation of certain luxury goods being granted more selectively. Consequently, import volumes declined sharply, and the current account deficit was contained at 4.4 percent of GDP.

In 1992, Tunisia's external position was affected by a sharp deterioration in its terms of trade, a slowdown in market growth in its trading partners, a sharp rise in externally financed imports associated with the construction of a trans-Tunisia pipeline, and a slow recovery in the tourist industry. These events caused the current account deficit to widen to 6.0 percent of GDP. However, with the doubling of capital inflows, mainly attributable to direct foreign investment associated with the gas pipeline, the overall balance of payments recorded a surplus of SDR 83 million (\$94 million), after having registered deficits in the previous two years, and gross international reserves amounted to 1.8 months of imports at the end of 1992 down from 1.9 months of imports in 1991.

An analysis of Tunisia's trade deficits by the separation of the contribution of export and import vol- umes, on the one hand, and terms of trade effects, on the other, reveals that events beyond the control of the authorities explain most of the deterioration in the trade balance during 1986-92 (Table 11). Of the cumulative increases in the trade deficit during this period, four fifths were accounted for by the terms of trade deterioration and the remaining one fifth by the decline in the net export volume.

Although this analysis suggests that the balance of payments remained vulnerable to exogenous shocks, the vulnerability of the external sector to such shocks would have been even greater if Tunisia had not pursued an outward-looking strategy. The strategy, involving an appropriate exchange rate policy and a gradual liberalization of the trade system underpinned by prudent demandmanagement policies, resulted in a shift in resources away from inefficient import-substituting activities to the export sector, which expanded and became more diversified.

The volume of Tunisia's exports grew at an annual average rate of 9 percent during 1986-90 compared with an annual average decline of 0.1 per- 
cent during 1982-85. Consequently, the ratio of merchandise exports to GDP increased from about 20 percent at the beginning of the adjustment program to an average of some 27 percent in 1991-92. The growth in the volume of nonenergy exports was more rapid and amounted on average to 10.3 percent a year during 1986-92. Such growth took place while Tunisia's export markets were growing at an annual rate of 5.7 percent, leading to a gain in market shares.

Manufactured products, in particular, textiles and leather goods, have been the fastest-growing component of Tunisia's exports, with an annual compound growth rate of 13.4 percent in volume terms during 1986-92. As a result, the structure of exports has changed significantly since 1985 (Chart 9). The share of manufactured goods in total exports increased continuously from 30 percent in 1985 to 61 percent in 1992, with corresponding declines in the shares of energy and phosphate exports. Meanwhile, the shares of agricultural products remained broadly unchanged, with increases in shares of processed agricultural goods. These changes resulted in a more diversified export base but, at the same time, substantially increased the demand for imports because of the relatively high direct import content of manufactured exports. Despite the change in the composition of exports, the EC remained Tunisia's main export market, absorbing about three fourths of its total exports during 1986-92. Thus, Tunisia's export performance has remained sensitive to economic developments in the European Community.

\section{External Debt}

With the implementation of the macroeconomic adjustment and structural reform programs, which significantly strengthened the current account position, the growth in Tunisia's government and government-guaranteed external debt decelerated markedly during 1986-92, compared with the first half of the 1980s. As a result, the debt-to-GDP ratio, after having increased from 38 percent in 1981 to 63 percent in 1986 , declined gradually to 51 percent in 1992. Two percentage points represent outstanding purchases from the IMF. During

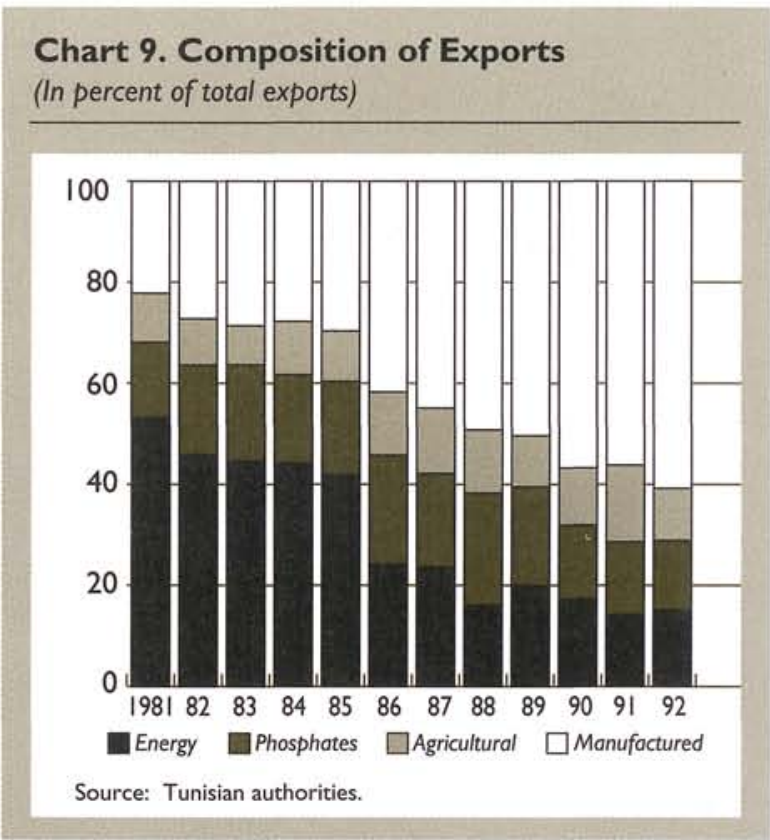

the adjustment program, the composition of external debt also changed materially. More specifically, the share of debt owed to multilateral organizations increased sharply, mainly because of large disbursements from the World Bank in support of structural reform efforts. In contrast, debt owed to Arab countries and financial institutions declined. In 1992, Tunisia re-entered the international financial markets for the first time since 1986 by securing a syndicated loan in the amount of $\$ 110$ million.

Prudent external debt policies, together with the strong growth in exports of goods and services, resulted in an improvement in Tunisia's debt-service ratio. Debt-service payments, including obligations to the IMF, as a percentage of current account receipts declined from 28 percent in 1986 to slightly below 20 percent in 1992. Of the latter, one third were accounted for by interest payments and two thirds by amortization payments. Throughout this period, Tunisia managed to honor its debt-service obligations as scheduled and maintained its excellent credit standing. 


\section{The Challenges and the Lessons}

T unisia's progress in its structural and macroeconomic adjustment efforts during 1986-92 provides a prime example of the successful transformation of an economy from one heavily regulated by government to one based on market orientation and from an inward-looking to an export-oriented one. Although Tunisia's experience offers a wealth of lessons for countries embarking on reform, the process is not complete.

Tunisia has set for itself ambitious objectives under the Eighth Development Plan (1992-96) to sustain a high rate of economic growth, which is essential to improving living conditions and tackling the persistent unemployment problem while continuing to reduce inflation and strengthening the external sector position. In particular, although job creation kept pace during the adjustment period with the rapid growth of the labor force, the durable reduction of the unemployment rate will require significant and challenging reforms in the period ahead.

Achievement of the objectives of the Eighth Development Plan will necessitate further improvements in efficiency and an increase in the mobilization of domestic savings. To these ends, Tunisia is forging ahead with its reforms in a number of areas. The authorities envisage

- phasing out price and trade controls completely to further improve resource allocation;

- introducing greater flexibility in the labor market to link remuneration more closely with productivity and to foster an expansion in employment opportunities;

- adopting a unified investment code to harmonize incentives across sectors;

- establishing a foreign exchange market in the context of which the exchange rate will be determined by market forces;

- completing the reform of the banking and financial sectors to enhance further financial intermediation;

- stepping up public enterprise restructuring and privatization to reduce the reliance of public enterprises on the budget and to widen the scope for private sector activity;

- narrowing the budget deficit to further lower the absorption of resources by the Government and continue to improve Tunisia's debt profile; and

- maintaining a restrained monetary policy stance aimed at dampening demand pressures and supporting the growth of the private sector.

The success of Tunisia's adjustment efforts thus far should be viewed as a foundation upon which the authorities can continue to build an edifice of prosperity for the Tunisian people. Against this background, the following lessons can be drawn from Tunisia's experience.

First, adjustment is not a passing phase but rather a continuous process of sound economic management. Confronted with rising financial imbalances and structural rigidities, Tunisia took major actions to tackle its immediate financial and economic problems. But the consolidation of the progress achieved thus far and further improvements call for the completion of the ongoing reforms and constant vigilance.

Second, successful adjustment requires comprehensive reforms. Tunisia flirted in 1985 and the early part of 1986 with a piecemeal approach to adjustment; it did not work. The package that was put in place in late 1986 involved a comprehensive set of measures, with macroeconomic policies and structural reforms reinforcing each other. In particular, the devaluation of the dinar was supported by a reduction in the budget deficit and in the rate of credit expansion, as well as by an initial liberalization of price controls.

Third, the speed of adjustment has to be dictated, in part, by the need to sequence policies appropriately. The exchange rate action, taken up front, and the restrained demand-management policies made it possible to reduce quantitative restrictions without undermining the external sector position. In addition, the liberalization of price 
controls was coordinated with the reduction of quantitative trade restrictions so as to foster competition in the domestic market.

Fourth, a key to economic growth is efficiency. The level of public sector investment is not critical. In fact, the ratio of public investment to GDP declined as the Government reduced somewhat its own direct investment as a ratio to GDP but sharply cut back investment outlays of public enterprises. The resulting release of resources to the private sector, combined with the improved incentive structure, led to a pickup in private sector investment that resulted in a reversal in 1989 of the downward trend in the ratio of nongovernment investment to GDP. Furthermore, in Tunisia the cutback in public capital outlays was accompanied by an overall decline in the incremental capital-output ratio, suggesting an increase in the efficiency of investment.

Fifth, the successful implementation of reforms requires thorough preparation. In Tunisia, the progress made in public enterprise reform was less than envisaged because elaborating performance contracts took longer than expected, owing to the need to undertake specific studies of the enterprises concerned. Privatization suffered not only from structural problems that needed to be resolved before enterprises could be offered for sale, but also from limitations on the domestic financial market. By contrast, the thorough preparation of the reform of the value-added tax and of the direct income tax made for a relatively smooth implementation.

Sixth, the private sector responds well to improvements in the incentive structure. This is evinced by the rise in private sector savings, investment, exports, and workers' remittances associated with the liberalization measures, the exchange rate action, and the increase in real interest rates.

Seventh, an outward-looking adjustment strategy promotes economic growth and enhances the country's external sector position. The response of the export sector in Tunisia to the increased competitiveness generated by the depreciation of the currency and a restrained incomes policy fostered economic growth. The financial policies that Tunisia pursued and the liberalization of the import sector served to check inflation in spite of the simultaneous substantial decontrol of prices.

Eighth, the prompt adaptation of policies to exogenous factors is essential for the successful achievement of the adjustment program's objectives. In 1990-91, Tunisia was hard hit by the Middle East crisis. The Government rapidly adapted its policies in 1991, taking steps to generate additional revenue, restraining current expenditures, and stepping up foreign-financed government investment so as to mitigate the impact of the events on the economy.

Ninth, successful adjustment requires steadfastness; interruptions in the process can easily erode the progress achieved during the adjustment period. Tunisia persevered with its adjustment efforts without interruption. Two corollary lessons can be drawn from Tunisia's experience:

- The continuity of adjustment efforts requires a sustained political commitment that, in turn, depends on political stability. During this period, although there was a transition in the Government in late 1987, this was effected in an orderly manner, and political stability was maintained throughout the adjustment period.

- Adequate social security systems and safety nets are essential to avoid an erosion in the support for the adjustment process. Tunisia has an extensive social security system that, although subject to improvement, provided a degree of protection to the more vulnerable segments of the population. The budget allocated increased expenditures for the social sectors, particularly for health and education. In addition, the reduction in subsidies was designed such that the impact on the poorest segments of the population was minimized by phasing in the reductions and improving the targeting of the subsidies and direct income support. Furthermore, the three-year wage pact (1990-92) formalized a consensus about social priorities and provided stability, preventing potential problems associated with annual negotiations. Finally, the growing economy generated employment opportunities that checked the rise in the rate of unemployment.

Last, the successful implementation of an adjustment program requires a strong administration. Tunisia was fortunate in having a highly qualified civil service; the Government's investment in education following independence did indeed yield important returns. Furthermore, although real salaries in the civil service eroded somewhat, the adjustments provided under the wage pact prevented a major "brain drain" from the public to the private sector that would have reduced the Government's implementation capacity. 


\section{Appendix I Statistical Tables}

\section{Table AI. Sectoral Distribution of Real GDP Growth'}

(In percent)

\begin{tabular}{lrrrrrrr} 
& 1986 & 1987 & 1988 & 1989 & 1990 & 1991 & 1992 \\
\hline Agriculture and fishing & -12.2 & 20.5 & -25.8 & 5.7 & 27.7 & 14.7 & 5.8 \\
Mining & 25.3 & 6.8 & 1.0 & 7.2 & -6.7 & 0.1 & -1.1 \\
Hydrocarbons, electricity, and water & -1.4 & -3.3 & -0.3 & 1.0 & -5.9 & 11.3 & 0.8 \\
Manufacturing & 4.8 & 4.4 & 6.5 & 6.0 & 11.1 & 4.1 & 8.0 \\
Food processing & 4.7 & 1.8 & 4.2 & -6.1 & 15.0 & 6.3 & 14.4 \\
Construction materials and glass & 1.1 & 4.9 & 8.0 & 7.2 & 7.8 & 1.5 & 4.3 \\
Mechanical and electrical industries & 0.4 & -0.5 & 4.1 & 7.4 & 9.6 & 3.8 & 3.9 \\
Chemical and rubber industries & 14.9 & 8.4 & 12.6 & 3.8 & 4.6 & 2.9 & 4.8 \\
Textiles, clothing, and leather & 5.6 & 7.6 & 8.0 & 13.5 & 14.9 & 4.0 & 8.3 \\
Woodwork, paper, and other & 4.2 & 5.2 & 5.1 & 7.4 & 6.1 & 4.8 & 7.8 \\
Manufacturing, excluding food processing & 4.8 & 5.2 & 7.2 & 9.3 & 10.2 & 3.5 & 6.5 \\
Construction and public works & -13.2 & -4.8 & -4.6 & 11.9 & 15.3 & 1.0 & 8.6 \\
Services & 1.4 & 6.4 & 8.0 & 2.7 & 3.3 & -1.3 & 10.1 \\
Transport and telecommunications & -3.2 & 9.8 & 6.4 & 5.0 & 3.7 & 1.8 & 12.5 \\
Tourism & -0.7 & 37.2 & 11.6 & -2.8 & -0.8 & -29.6 & 53.9 \\
Commerce and other services & 2.8 & 3.5 & 10.2 & 2.5 & 3.7 & 2.1 & 7.5 \\
Government wages and salaries & 1.2 & 2.5 & 3.2 & 4.0 & 3.8 & 4.6 & 4.2 \\
Indirect taxes minus subsidies & 0.8 & 6.7 & 0.1 & 1.9 & 8.1 & 2.1 & 8.5 \\
GDP (at constant market prices) & -1.1 & 6.7 & 0.1 & 3.7 & 7.6 & 3.9 & 8.0 \\
\hline
\end{tabular}

Source: Ministry of Planning and Regional Development.

I On the basis of values in constant 1980 prices for 1986 and in constant 1990 prices for the subsequent years.

\section{Table A2. Supply and Use of Resources-Real Growth Rates'} (In percent)

\begin{tabular}{|c|c|c|c|c|c|c|c|}
\hline & 1986 & 1987 & 1988 & 1989 & 1990 & 1991 & 1992 \\
\hline Consumption & 1.1 & 1.3 & 1.3 & 4.0 & 6.3 & 3.2 & 5.7 \\
\hline Private sector ${ }^{2}$ & 2.0 & 1.8 & 2.8 & 3.6 & 7.2 & 2.6 & 6.0 \\
\hline Central Government & -3.7 & -0.1 & -6.7 & 6.8 & 1.2 & 6.9 & 4.5 \\
\hline Gross fixed capital formation & -17.5 & -10.1 & -4.0 & 12.4 & 17.5 & 1.6 & 21.1 \\
\hline Domestic demand & -3.5 & 0.7 & -1.5 & 7.9 & 10.7 & 1.3 & 9.2 \\
\hline Exports of goods and nonfactor services & 5.2 & 13.4 & 21.5 & 5.0 & 1.8 & -3.8 & 13.1 \\
\hline Imports of goods and nonfactor services & -2.1 & -3.5 & 16.1 & 14.6 & 8.9 & -8.3 & 15.5 \\
\hline GDP (at constant market prices) & -1.1 & 6.7 & 0.1 & 3.7 & 7.6 & 3.9 & 8.0 \\
\hline
\end{tabular}

Source: Ministry of Planning and Regional Development.

I On the basis of values in constant 1980 prices for 1986 and in constant 1990 prices for the subsequent years.

Includes all economic agents except the Central Government. 
Table A3. Sectoral Distribution of GDP

(In millions of dinars; at current prices)

\begin{tabular}{|c|c|c|c|c|c|c|c|}
\hline & 1986 & 1987 & 1988 & 1989 & 1990 & 1991 & 1992 \\
\hline Agriculture and fishing & 933.0 & $1,226.0$ & $1,018.0$ & $1,172.0$ & $1,587.0$ & $1,928.0$ & $2,166.0$ \\
\hline Mining & 57.9 & 59.7 & 84.7 & 126.7 & 93.3 & 88.2 & 77.8 \\
\hline Hydrocarbons, electricity, and water & 646.1 & 745.3 & 763.3 & 843.1 & 819.7 & 860.9 & 899.7 \\
\hline $\begin{array}{l}\text { Manufacturing } \\
\text { Food processing } \\
\text { Construction materials and glass } \\
\text { Mechanical and electrical industries } \\
\text { Chemical and rubber industries } \\
\text { Textiles, clothing, and leather } \\
\text { Woodwork, paper, and other }\end{array}$ & $\begin{array}{r}920.1 \\
216.6 \\
151.1 \\
134.8 \\
42.6 \\
236.8 \\
138.2\end{array}$ & $\begin{array}{r}1,049.6 \\
231.5 \\
165.4 \\
147.4 \\
57.6 \\
291.5 \\
156.2\end{array}$ & $\begin{array}{r}1,210.6 \\
257.4 \\
193.7 \\
163.4 \\
86.0 \\
333.7 \\
176.4\end{array}$ & $\begin{array}{r}1,387.0 \\
265.0 \\
218.9 \\
190.0 \\
99.7 \\
411.4 \\
202.0\end{array}$ & $\begin{array}{r}1,641.2 \\
320.8 \\
247.1 \\
222.3 \\
102.5 \\
517.4 \\
231.1\end{array}$ & $\begin{array}{r}1,835.6 \\
365.5 \\
270.4 \\
250.5 \\
111.5 \\
576.4 \\
261.3\end{array}$ & $\begin{array}{r}2,093.7 \\
445.2 \\
297.2 \\
267.8 \\
118.2 \\
665.8 \\
299.5\end{array}$ \\
\hline Manufacturing, excluding food processing & 703.5 & 818.1 & 953.2 & $1,122.0$ & $1,320.4$ & $1,470.1$ & $1,648.5$ \\
\hline Construction and public works & 378.4 & 367.6 & 378.0 & 441.4 & 540.0 & 588.0 & 677.6 \\
\hline $\begin{array}{l}\text { Services } \\
\text { Transport and telecommunications } \\
\text { Tourism } \\
\text { Commerce and other services } \\
\text { Government services } \\
\text { GDP at factor cost }\end{array}$ & $\begin{array}{r}3,150.5 \\
379.3 \\
210.0 \\
1,691.8 \\
869.4 \\
6,086.0\end{array}$ & $\begin{array}{r}3,536.8 \\
471.4 \\
304.2 \\
1,820.5 \\
940.7 \\
6,985.0\end{array}$ & $\begin{array}{r}4,132.4 \\
569.1 \\
374.0 \\
2,160.9 \\
1,028.4 \\
7,587.0\end{array}$ & $\begin{array}{r}4,612.8 \\
618.0 \\
407.0 \\
2,387.6 \\
1,200.2 \\
8,583.0\end{array}$ & $\begin{array}{r}5,047.8 \\
666.5 \\
432.0 \\
2,641.3 \\
1,308.0 \\
9,729.0\end{array}$ & $\begin{array}{r}5,426.3 \\
720.5 \\
332.0 \\
2,875.8 \\
1,498.0 \\
10,727.0\end{array}$ & $\begin{array}{r}6,291.2 \\
864.3 \\
500.0 \\
2,662.9 \\
1,675.0 \\
12,206.0\end{array}$ \\
\hline $\begin{array}{l}\text { Indirect taxes minus subsidies } \\
\text { GDP at market prices }\end{array}$ & $\begin{array}{r}935.0 \\
7,021.0\end{array}$ & $\begin{array}{l}1,012.0 \\
7,997.0\end{array}$ & $\begin{array}{l}1,098.0 \\
8,685.0\end{array}$ & $\begin{array}{l}1,078.0 \\
9,661.0\end{array}$ & $\begin{array}{r}1,261.0 \\
10,990.0\end{array}$ & $\begin{array}{r}1,467.0 \\
12,194.0\end{array}$ & $\begin{array}{r}1,722.0 \\
13,928.0\end{array}$ \\
\hline
\end{tabular}

Source: Ministry of Planning and Regional Development. 


\section{Table A4. Supply and Use of Resources}

\begin{tabular}{|c|c|c|c|c|c|c|c|}
\hline & 1986 & 1987 & 1988 & 1989 & 1990 & 1991 & 1992 \\
\hline & \multicolumn{7}{|c|}{ (In millions of dinars; at current prices) } \\
\hline $\begin{array}{l}\text { Consumption } \\
\text { Private sector' } \\
\text { Central Government }\end{array}$ & $\begin{array}{r}5,882.0 \\
4,955.0 \\
927.0\end{array}$ & $\begin{array}{r}6,429.0 \\
5,438.0 \\
991.0\end{array}$ & $\begin{array}{r}6,969.0 \\
5,970.0 \\
999.0\end{array}$ & $\begin{array}{l}7,860.0 \\
6,703.0 \\
1,157.0\end{array}$ & $\begin{array}{l}8,887.0 \\
7,642.2 \\
1,244.8\end{array}$ & $\begin{array}{l}9,947.0 \\
8,503.2 \\
1,443.8\end{array}$ & $\begin{array}{r}11,087.0 \\
9,496.7 \\
1,590.3\end{array}$ \\
\hline $\begin{array}{l}\text { Gross fixed capital formation } \\
\text { Private sector' } \\
\text { Central Government }\end{array}$ & $\begin{array}{r}1,685.0 \\
1,291.0 \\
394.0\end{array}$ & $\begin{array}{r}1,620.0 \\
1,299.0 \\
321.0\end{array}$ & $\begin{array}{r}1,680.0 \\
1,232.0 \\
448.0\end{array}$ & $\begin{array}{r}2,000.0 \\
1,597.0 \\
403.0\end{array}$ & $\begin{array}{r}2,515.0 \\
2,016.6 \\
498.4\end{array}$ & $\begin{array}{r}2,727.0 \\
2,030.0 \\
697.0\end{array}$ & $\begin{array}{r}3,492.4 \\
2,932.4 \\
560.0\end{array}$ \\
\hline Changes in stocks & -36.0 & 27.0 & 5.0 & 182.0 & 381.3 & 109.5 & 314.1 \\
\hline Domestic demand & $7,531.0$ & $8,067.0$ & $8,654.0$ & $10,042.0$ & $1 \mathrm{I}, 783.3$ & $12,783.5$ & $14,893.5$ \\
\hline $\begin{array}{l}\text { Net exports of goods and nonfactor services } \\
\text { Exports of goods and nonfactor services } \\
\text { Imports of goods and nonfactor services }\end{array}$ & $\begin{array}{r}-510.0 \\
2,161.0 \\
2,671.0\end{array}$ & $\begin{array}{r}-79.0 \\
2,799.0 \\
2,878.0\end{array}$ & $\begin{array}{r}31.0 \\
3,639.0 \\
3,608.0\end{array}$ & $\begin{array}{l}-381.0 \\
4,254.0 \\
4,634.0\end{array}$ & $\begin{array}{l}-793.3 \\
4,591.9 \\
5,385.2\end{array}$ & $\begin{array}{l}-589.5 \\
4,710.9 \\
5,300.4\end{array}$ & $\begin{array}{l}-965.5 \\
5,291.4 \\
6,256.9\end{array}$ \\
\hline GDP at market prices & $7,021.0$ & $7,997.0$ & $8,685.0$ & $9,661.0$ & $10,990.0$ & $12,194.0$ & $13,928.0$ \\
\hline $\begin{array}{l}\text { Net factor income from abroad } \\
\text { GNP at market prices }\end{array}$ & $\begin{array}{r}-50.0 \\
6,971.0\end{array}$ & $\begin{array}{r}-2.0 \\
7,995.0\end{array}$ & $\begin{array}{r}52.0 \\
8,737.0\end{array}$ & $\begin{array}{r}66.0 \\
9,727.0\end{array}$ & $\begin{array}{r}213.1 \\
11,203.0\end{array}$ & $\begin{array}{r}54.2 \\
12,248.0\end{array}$ & $\begin{array}{r}136.2 \\
14,164.0\end{array}$ \\
\hline Memorandum items: & \multicolumn{7}{|c|}{ (In percent of GDP) } \\
\hline Gross investment & 23.5 & 20.6 & 19.4 & 22.6 & 26.4 & 23.3 & 27.3 \\
\hline Gross domestic savings & 16.2 & 19.6 & 19.8 & 18.6 & 19.1 & 18.4 & 20.4 \\
\hline Gross national savings & 15.5 & 19.6 & 20.4 & 19.3 & 21.1 & 18.9 & 21.4 \\
\hline $\begin{array}{l}\text { Savings-investment gap } \\
\text { Private sector' } \\
\text { Central Government }\end{array}$ & $\begin{array}{r}-8.0 \\
-10.2 \\
2.2\end{array}$ & $\begin{array}{r}-1.0 \\
-2.6 \\
1.6\end{array}$ & $\begin{array}{l}1.0 \\
0.8 \\
0.1\end{array}$ & $\begin{array}{l}-3.3 \\
-1.8 \\
-1.4\end{array}$ & $\begin{array}{l}-5.3 \\
-4.8 \\
-0.5\end{array}$ & $\begin{array}{l}-4.4 \\
-1.3 \\
-3.1\end{array}$ & $\begin{array}{l}-6.0 \\
-5.9 \\
-0.1\end{array}$ \\
\hline
\end{tabular}

Source: Ministry of Planning and Regional Development.

IIncludes all economic agents except the Central Government 
Table A5. Production of Major Agricultural Crops (In thousands of metric tons)

\begin{tabular}{|c|c|c|c|c|c|c|}
\hline & 1987 & 1988 & 1989 & 1990 & 1991 & 1992 \\
\hline $\begin{array}{l}\text { Cereals } \\
\text { Hard wheat } \\
\text { Soft wheat } \\
\text { Barley }\end{array}$ & $\begin{array}{r}1,929 \\
1,065 \\
295 \\
569\end{array}$ & $\begin{array}{r}290 \\
167 \\
53 \\
70\end{array}$ & $\begin{array}{r}635 \\
333 \\
87 \\
215\end{array}$ & $\begin{array}{r}1,633 \\
897 \\
225 \\
511\end{array}$ & $\begin{array}{r}2,551 \\
1,424 \\
363 \\
765\end{array}$ & $\begin{array}{r}2,195 \\
1,323 \\
261 \\
611\end{array}$ \\
\hline $\begin{array}{l}\text { Fruits and vegetables } \\
\text { Citrus fruit } \\
\text { Dates } \\
\text { Tomatoes } \\
\text { Red peppers } \\
\text { Potatoes } \\
\text { Melons and watermelons } \\
\text { Almonds } \\
\text { Table grapes }\end{array}$ & $\begin{array}{r}250 \\
66 \\
485 \\
150 \\
188 \\
350 \\
46 \\
55\end{array}$ & $\begin{array}{r}230 \\
70 \\
400 \\
120 \\
180 \\
250 \\
30 \\
47\end{array}$ & $\begin{array}{r}260 \\
75 \\
440 \\
110 \\
180 \\
250 \\
38 \\
55\end{array}$ & $\begin{array}{r}237 \\
81 \\
530 \\
175 \\
217 \\
450 \\
52 \\
40\end{array}$ & $\begin{array}{r}226 \\
75 \\
580 \\
180 \\
220 \\
350 \\
40 \\
55\end{array}$ & $\begin{array}{r}185 \\
75 \\
550 \\
190 \\
218 \\
380 \\
45 \\
60\end{array}$ \\
\hline Olives for oil & 570 & 500 & 270 & 650 & 825 & 1,400 \\
\hline $\begin{array}{l}\text { Other } \\
\text { Meat } \\
\text { Sugar beets } \\
\text { Milk } \\
\text { Fish }\end{array}$ & $\begin{array}{l}125 \\
303 \\
356 \\
100\end{array}$ & $\begin{array}{l}133 \\
256 \\
370 \\
103\end{array}$ & $\begin{array}{r}130 \\
230 \\
380 \\
95\end{array}$ & $\begin{array}{r}132 \\
289 \\
400 \\
88\end{array}$ & $\begin{array}{r}136 \\
210 \\
419 \\
88\end{array}$ & $\begin{array}{r}141 \\
291 \\
449 \\
90\end{array}$ \\
\hline
\end{tabular}

Source: Ministry of Agriculture.

Table A6. Supply and Use of Cereals' (In thousands of metric tons)

\begin{tabular}{|c|c|c|c|c|c|c|c|}
\hline & $1985 / 86$ & $1986 / 87$ & $1987 / 88$ & $1988 / 89$ & $1989 / 90$ & $1990 / 91$ & 1991/92 \\
\hline \multicolumn{8}{|l|}{ Hard wheat } \\
\hline Production & 378.0 & $1,065.1$ & 167.1 & 333.3 & 897.2 & I,423.5 & 1,323.1 \\
\hline $\begin{array}{l}\text { Commercialization }{ }^{2} \\
\text { (In percent of previous year) }\end{array}$ & $\begin{array}{l}429.0 \\
(40.1)\end{array}$ & $\begin{array}{l}190.6 \\
(50.4)\end{array}$ & $\begin{array}{l}537.7 \\
(50.5)\end{array}$ & $\begin{array}{l}134.8 \\
(80.7)\end{array}$ & $\begin{array}{l}288.1 \\
(86.4)\end{array}$ & $\begin{array}{l}483.7 \\
(53.9)\end{array}$ & $\begin{array}{c}772.4 \\
(54.3)\end{array}$ \\
\hline Imports & $274.0^{\prime}$ & 307.6 & 525.2 & $431.1^{\prime}$ & $100.0^{\prime}$ & 127.5 & \\
\hline Consumption ${ }^{3}$ & 587.0 & 637.0 & 720.0 & 778.0 & 649.0 & 686.0 & 753.0 \\
\hline Change in stocks & -37.0 & 32.0 & 82.0 & 67.0 & & & \\
\hline Producer price $(D / t)^{4}$ & 160.0 & 185.0 & 210.0 & 225.0 & 245.0 & 245.0 & 260.0 \\
\hline Real producer price index 5 & 111.3 & 119.2 & 127.4 & 126.7 & 129.6 & 120.2 & 120.9 \\
\hline \multicolumn{8}{|l|}{ Soft wheat } \\
\hline Production & 96.0 & 291.8 & 52.9 & 87.0 & 224.6 & 362.6 & 231.0 \\
\hline Commercialization ${ }^{2}$ & 177.0 & 75.8 & 222.2 & 38.1 & 68.1 & 132.3 & 228.2 \\
\hline $\begin{array}{l}\text { (In percent of previous year) } \\
\text { Imports }\end{array}$ & $(56.9)$ & $(79.0)$ & $(75.4)$ & (72.5) & (78.3) & $(58.9)$ & $(62.9)$ \\
\hline $\begin{array}{l}\text { Imports } \\
\text { Consumption }{ }^{3}\end{array}$ & 634.0 & $\begin{array}{l}423.1 \\
566.4\end{array}$ & $\begin{array}{l}637.3 \\
695.0\end{array}$ & $\begin{array}{l}597.4 \\
730.8\end{array}$ & 621.7 & 487.6 & 623.1 \\
\hline Change in stocks & 61.0 & 113.0 & 148.0 & 20.0 & 722.0 & 725.6 & 853.1 \\
\hline Producer price $(D / t)$ & 160.0 & 170.0 & 190.0 & 199.0 & 209.0 & 209.0 & 225.0 \\
\hline Real producer price index 5 & 124.3 & 122.3 & 128.7 & 125.1 & 123.3 & 114.4 & 116.8 \\
\hline \multicolumn{8}{|l|}{ Barley } \\
\hline Production & 118.0 & 536.5 & 62.9 & 199.8 & 477.5 & 720.5 & 569.8 \\
\hline $\begin{array}{l}\text { Commercialization }{ }^{2} \\
\text { (In percent of previous year) }\end{array}$ & $\begin{array}{l}177.0 \\
(26.0)\end{array}$ & $\begin{array}{c}12.1 \\
(10.2)\end{array}$ & $\begin{array}{l}210.8 \\
(39.3)\end{array}$ & $\begin{array}{c}6.6 \\
(10.5)\end{array}$ & $\begin{array}{r}29.4 \\
(14.7)\end{array}$ & $\begin{array}{l}143.4 \\
(30.0)\end{array}$ & $\begin{array}{l}291.6 \\
(40.5)\end{array}$ \\
\hline Imports & 110.0 & 22.0 & 485.5 & 169.2 & 125.7 & - & - \\
\hline Consumption ${ }^{3}$ & 76.0 & 48.0 & 471.0 & 239.2 & 127.3 & 136.5 & 236.2 \\
\hline Change in stocks & 84.0 & -67.0 & 97.0 & -53.0 & & & \\
\hline Producer price $(\mathrm{D} / \mathrm{t})$ & 110.0 & 120.0 & 140.0 & 145.0 & 150.0 & 150.0 & 150.0 \\
\hline Real producer price index ${ }^{5}$ & 115.0 & 112.6 & 123.8 & 114.8 & 115.1 & 106.8 & 101.2 \\
\hline \multicolumn{8}{|c|}{$\begin{array}{l}\text { Source: Ministry of Agriculture; and Central Bank of Tunisia. } \\
\text { 'By crop year (July/June). } \\
\text { 2Commercialization of the previous year's crop. } \\
3 \text { Officially controlled consumption. } \\
\text { } 10 / t \text {, dinars per ton. } \\
\text { s/ndex } 1980=100 \text {. Nominal producer prices deflated by the consumer price index. }\end{array}$} \\
\hline
\end{tabular}


Table A7. Producer Prices of Principal Agricultural Commodities' (In dinars per ton)

\begin{tabular}{|c|c|c|c|c|c|c|c|}
\hline & 1986 & 1987 & 1988 & 1989 & 1990 & 1991 & 1992 \\
\hline \multicolumn{8}{|l|}{ Cereals } \\
\hline Hard wheat & 160.0 & 185.0 & 210.0 & 225.0 & 245.0 & 245.0 & 260.0 \\
\hline Soft wheat & 160.0 & 170.0 & 190.0 & 199.0 & 209.0 & 209.0 & 225.0 \\
\hline Barley & 110.0 & 120.0 & 140.0 & 145.0 & 150.0 & 150.0 & 150.0 \\
\hline Sugar beets & 33.0 & 33.0 & 33.0 & 35.7 & 35.7 & 38.7 & 47.5 \\
\hline \multicolumn{8}{|l|}{ Olives for oil } \\
\hline High grade & 980.0 & $1,100.0$ & $1,250.0$ & $1,500.0$ & $1,710.0$ & $1,750.0$ & $1,750.0$ \\
\hline Low grade & 750.0 & 870.0 & $1,000.0$ & $1,260.0$ & $1,360.0$ & $1,390.0$ & $1,390.0$ \\
\hline Tomatoes & 58.0 & 60.0 & 65.0 & 70.0 & 70.0 & 70.0 & 70.0 \\
\hline
\end{tabular}

Source: Ministry of Agriculture; and Central Bank of Tunisia.

'For crop year (July/June).

Table A8. Energy Production and Consumption

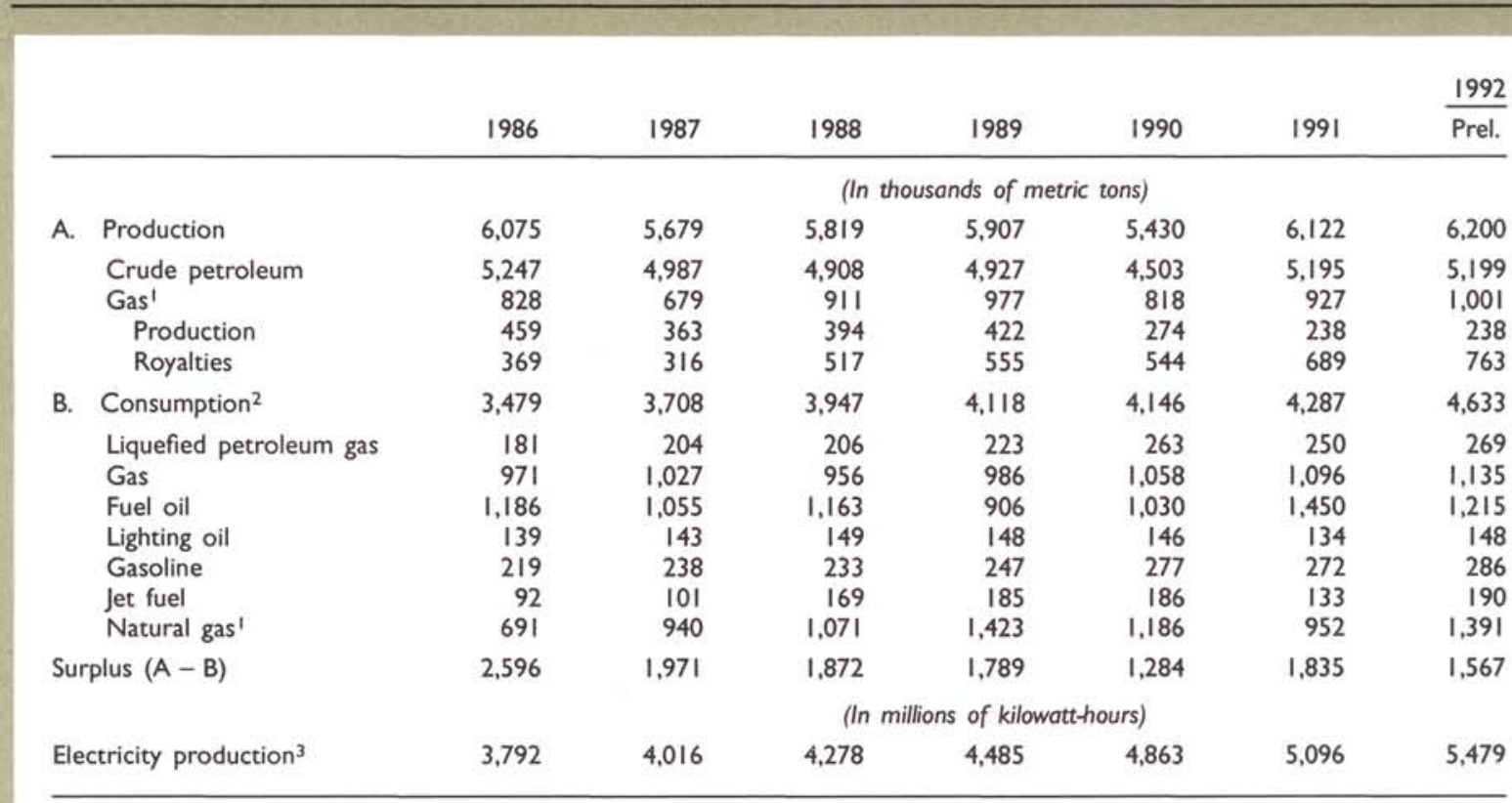

Source: Ministry of Energy and Mining.

I In thousands of tons of oil equivalent.

Including imports.

3 production by the state company (excluding production by private plants). 


\section{Table A9. Indicators of Tourist Activity}

\begin{tabular}{|c|c|c|c|c|c|c|c|}
\hline & & & & & & & 1992 \\
\hline & 1986 & 1987 & 1988 & 1989 & 1990 & 1991 & Prel. \\
\hline \multicolumn{8}{|l|}{$\begin{array}{l}\text { Annual fixed investment } \\
\text { in tourism }\end{array}$} \\
\hline (in millions of dinars) & 81.0 & 65.0 & 84.0 & 109.0 & 121.0 & 143.0 & 204.0 \\
\hline $\begin{array}{l}\text { Accommodation available } \\
\text { (in thousands of beds) }\end{array}$ & 98.7 & 100.5 & 104.9 & 109.8 & 116.5 & 123.2 & 135.6 \\
\hline $\begin{array}{l}\text { Number of foreign visitors } \\
\text { (in thousands) }\end{array}$ & $1,502.0$ & $1,874.7$ & $3,468.0$ & $3,222.2$ & $3,204.0$ & $3,224.0$ & $3,540.0$ \\
\hline $\begin{array}{l}\text { Visitor bed-nights } \\
\text { (in thousands) } \\
\text { Of which: Foreigners }\end{array}$ & $\begin{array}{l}13,734.0 \\
12,550.0\end{array}$ & $\begin{array}{l}18,556.7 \\
17,516.0\end{array}$ & $\begin{array}{l}20,661.0 \\
19,602.0\end{array}$ & $\begin{array}{l}20,126.0 \\
19,011.0\end{array}$ & $\begin{array}{l}20,019.0 \\
18,841.0\end{array}$ & $\begin{array}{l}13,793.0 \\
12,443.0\end{array}$ & $\begin{array}{l}21,718.1 \\
20,206.2\end{array}$ \\
\hline $\begin{array}{l}\text { Average length of stay } \\
\text { (in days) }\end{array}$ & 8.4 & 9.3 & 5.7 & 5.9 & 5.9 & 3.9 & 5.7 \\
\hline $\begin{array}{l}\text { Average occupancy rate } \\
\text { (in percent) }\end{array}$ & 45.5 & 58.8 & 62.2 & 57.6 & 54.0 & 37.6 & 52.0 \\
\hline $\begin{array}{l}\text { Tourism receipts } \\
\text { (in millions of dinars) }\end{array}$ & 385.0 & 569.0 & $1,086.1$ & 880.7 & 827.8 & 630.3 & 932.5 \\
\hline $\begin{array}{l}\text { Daily expenditure per tourist } \\
\text { (in dinars) }\end{array}$ & 30.7 & 32.5 & 55.4 & 46.3 & 43.9 & 50.7 & 46.1 \\
\hline
\end{tabular}

Sources: National Tourist Board; and Central Bank of Tunisia.

Table A 10. Consumer Price Index

(Annual averages; 1983 $=100$ )

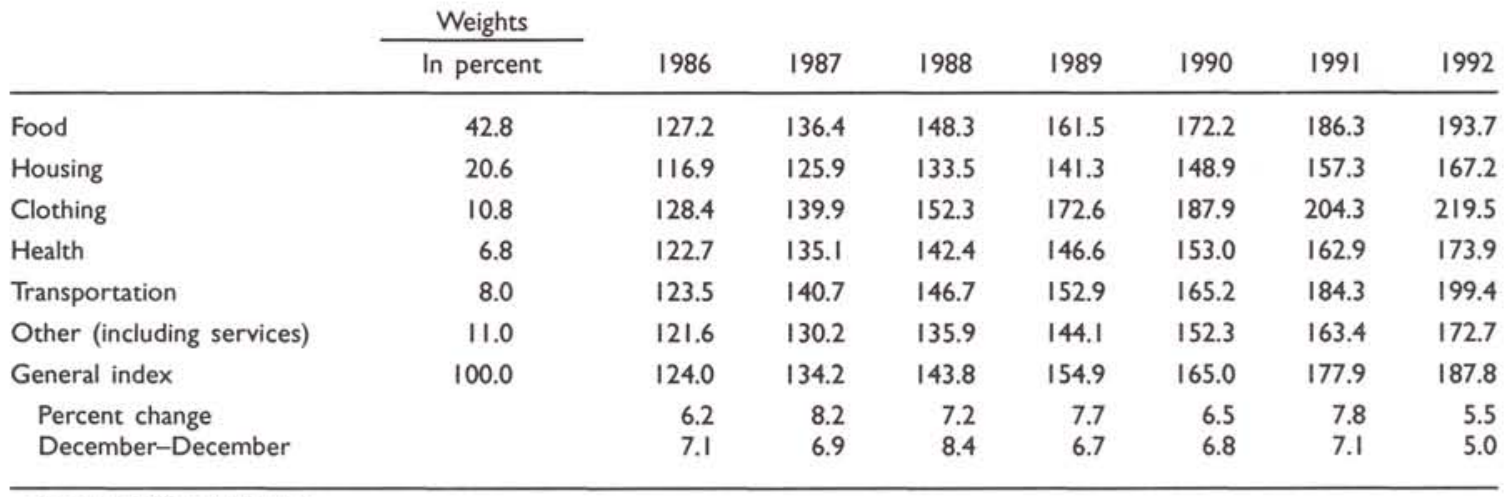

Source: Tunisian authorities. 
Table AII. Consumer Price Index by Price Regime

(Percent change, December-December)

\begin{tabular}{lrrrrrrr}
\hline Price regime & 1986 & 1987 & 1988 & 1989 & 1990 & 1991 & 1992 \\
\hline Fixed prices & 7.6 & 3.5 & 3.0 & 7.3 & 7.0 & 7.1 & $\ldots .1$ \\
Homologation & 10.6 & 8.8 & 11.1 & 14.8 & 7.8 & 5.3 & 5.8 \\
Auto-homologation & 10.5 & 7.8 & 7.0 & 7.2 & 3.6 & 4.5 & 4.8 \\
Controlled freedom & 10.3 & 3.5 & 6.0 & 5.7 & 7.7 & 9.7 & $\ldots .1$ \\
Free prices & 5.9 & 8.5 & 11.3 & 6.1 & 7.2 & 7.4 & 4.8 \\
$\quad$ Total & 7.1 & 6.9 & 8.4 & 6.7 & 6.8 & 7.1 & 5.0 \\
\hline
\end{tabular}

Source: Tunisian authorities.

'Regimes of fixed prices and controlled freedom were abolished at the beginning of 1992.

Table AI2. Producer Price Index

(Annual averages; $1983=100$ )

\begin{tabular}{|c|c|c|c|c|c|c|c|c|}
\hline & \multirow{2}{*}{$\frac{\text { Weights' }}{\text { In percent }}$} & \multirow[b]{2}{*}{1986} & \multirow[b]{2}{*}{1987} & \multirow[b]{2}{*}{1988} & \multirow[b]{2}{*}{1989} & \multirow[b]{2}{*}{1990} & \multirow[b]{2}{*}{1991} & \multirow{2}{*}{$\frac{1992}{\text { Jan.-Sept. }}$} \\
\hline & & & & & & & & \\
\hline Manufacturing & 47.1 & 124.0 & 134.1 & 146.7 & 158.2 & 167.7 & 174.5 & 178.4 \\
\hline Food processing & 10.3 & 124.6 & 132.2 & 135.8 & 145.9 & 159.9 & 169.5 & 178.8 \\
\hline Construction materials and glass & 7.6 & 118.1 & 120.7 & 133.7 & 137.5 & 144.4 & 157.2 & 161.3 \\
\hline Mechanical and electrical products & 7.0 & 120.6 & 137.9 & 152.0 & 168.0 & 180.4 & 184.7 & 185.3 \\
\hline Chemicals and rubber & 3.0 & 126.7 & 142.2 & 157.7 & 162.4 & 173.6 & 177.1 & 185.0 \\
\hline Textiles, clothing, and leather & 12.4 & 127.2 & 135.4 & 149.4 & 164.2 & 169.5 & 174.1 & 175.8 \\
\hline Other manufacturing & 6.8 & 125.7 & 142.9 & 163.6 & 178.1 & 186.3 & 190.5 & 191.8 \\
\hline Mining & 4.9 & 104.4 & 107.5 & 112.1 & 140.0 & 132.8 & 140.8 & 128.7 \\
\hline Hydrocarbons & 41.8 & 152.7 & 170.5 & 186.8 & 191.1 & 191.1 & 189.5 & 189.6 \\
\hline Electricity and water & 6.2 & 113.8 & 119.2 & 122.5 & 125.8 & 128.3 & 134.1 & 135.3 \\
\hline General index & 100.0 & 134.4 & 147.2 & 160.2 & 169.1 & 173.3 & 176.4 & 178.0 \\
\hline Percent change & & 10.5 & 9.5 & 8.8 & 5.6 & 2.5 & 1.8 & $1.0^{2}$ \\
\hline
\end{tabular}

Source: Tunisian authorities.

'Based on value added of each sector or subsector.

${ }^{2}$ Over corresponding period in 1991. 
Table A|3. Wage and Employment Indicators

\begin{tabular}{lrrrrrrr} 
& 1986 & 1987 & 1988 & 1989 & 1990 & 1991 & 1992 \\
\hline Total wage bill (in millions of dinars) & 2,441 & 2,555 & 2,755 & 3,075 & 3,330 & 3,736 & 4,139 \\
$\quad$ Percent change & 4.0 & 4.7 & 7.8 & 11.6 & 8.3 & 12.2 & 10.8 \\
Number of wage earners (in thousands) & 1,147 & 1,172 & 1,203 & 1,237 & 1,268 & 1,294 & 1,330 \\
Average annual wage (in dinars) & 2,128 & 2,180 & 2,290 & 2,486 & 2,626 & 2,887 & 3,112 \\
$\quad$ Percent change & 2.4 & 2.5 & 5.1 & 8.6 & 5.6 & 9.9 & 7.8 \\
Real average annual wage & & & & & & & \\
$\quad$ (percent change) & -3.8 & -5.7 & -2.1 & 0.9 & -0.9 & 2.3 & 1.8 \\
SMAG $^{2}$ (in dinars per day) & 2.900 & 3.050 & 3.200 & 3.213 & 3.661 & 3.761 & 4.061 \\
SMIG $^{3}$ (in dinars per hour) & 0.481 & 0.505 & 0.529 & 0.549 & 0.577 & 0.625 & 0.649 \\
Consumer price index (percent change) & 6.2 & 8.2 & 7.2 & 7.7 & 6.5 & 7.8 & 5.5 \\
\hline
\end{tabular}

Source: Ministry of Planning and Regional Development.

'Deflated by the average annual increase in the consumer price index.

2 Minimum wage in the agricultural sector.

${ }^{3}$ Minimum wage in the nonagricultural sector.

Table Al4. Gross Fixed Investment by Economic Sector and Financing (In millions of dinars)

\begin{tabular}{|c|c|c|c|c|c|c|c|}
\hline & 1986 & 1987 & 1988 & 1989 & 1990 & $199 \mid$ & 1992 \\
\hline Agriculture and fishing & 275 & 261 & 280 & 347 & 389 & 459 & 509 \\
\hline $\begin{array}{l}\text { Industry } \\
\text { Mining } \\
\text { Hydrocarbons } \\
\text { Electricity and water } \\
\text { Manufacturing } \\
\text { Food processing } \\
\text { Construction materials and glass } \\
\text { Mechanical and electrical goods } \\
\text { Chemical and rubber products } \\
\text { Textiles and leather products } \\
\text { Woodwork and other }\end{array}$ & $\begin{array}{r}583 \\
29 \\
153 \\
111 \\
290 \\
24 \\
75 \\
60 \\
85 \\
26 \\
20\end{array}$ & $\begin{array}{r}522 \\
17 \\
132 \\
99 \\
274 \\
31 \\
74 \\
45 \\
56 \\
53 \\
15\end{array}$ & $\begin{array}{r}487 \\
26 \\
116 \\
79 \\
266 \\
38 \\
49 \\
81 \\
18 \\
63 \\
28\end{array}$ & $\begin{array}{r}592 \\
31 \\
108 \\
83 \\
370 \\
42 \\
54 \\
71 \\
23 \\
132 \\
38\end{array}$ & $\begin{array}{r}725 \\
33 \\
152 \\
106 \\
434 \\
72 \\
66 \\
74 \\
33 \\
145 \\
45\end{array}$ & $\begin{array}{r}797 \\
33 \\
188 \\
107 \\
469 \\
73 \\
77 \\
74 \\
30 \\
160 \\
55\end{array}$ & $\begin{array}{r}1,121 \\
32 \\
451 \\
146 \\
492 \\
79 \\
80 \\
83 \\
44 \\
140 \\
66\end{array}$ \\
\hline $\begin{array}{l}\text { Construction and public infrastructure } \\
\text { Housing } \\
\text { Construction and public works } \\
\text { Public infrastructure }\end{array}$ & $\begin{array}{r}544 \\
391 \\
5 \\
148\end{array}$ & $\begin{array}{r}570 \\
390 \\
10 \\
170\end{array}$ & $\begin{array}{r}571 \\
365 \\
15 \\
191\end{array}$ & $\begin{array}{r}624 \\
390 \\
20 \\
214\end{array}$ & $\begin{array}{r}738 \\
455 \\
25 \\
258\end{array}$ & $\begin{array}{r}821 \\
500 \\
28 \\
293\end{array}$ & $\begin{array}{r}908 \\
540 \\
33 \\
335\end{array}$ \\
\hline $\begin{array}{l}\text { Services } \\
\text { Transport and communications } \\
\text { Tourism } \\
\text { Commerce and other }\end{array}$ & $\begin{array}{r}283 \\
181 \\
81 \\
21\end{array}$ & $\begin{array}{r}267 \\
180 \\
65 \\
22\end{array}$ & $\begin{array}{r}343 \\
189 \\
84 \\
70\end{array}$ & $\begin{array}{r}437 \\
284 \\
109 \\
44\end{array}$ & $\begin{array}{r}663 \\
464 \\
121 \\
78\end{array}$ & $\begin{array}{r}651 \\
459 \\
143 \\
49\end{array}$ & $\begin{array}{r}954 \\
707 \\
204 \\
43\end{array}$ \\
\hline Total & 1,685 & 1,620 & 1,680 & 2,000 & 2,515 & 2,727 & 3,492 \\
\hline Central Government & 394 & 321 & 449 & 403 & 498 & 697 & 560 \\
\hline Other public entities & 552 & 571 & 377 & 575 & 792 & 643 & ... \\
\hline Private enterprises and households & 739 & 728 & 854 & 1,022 & 1,225 & 1,387 & .. \\
\hline $\begin{array}{l}\text { Financing requirements' } \\
\text { Gross national savings } \\
\text { (In percent of GNP) } \\
\text { Foreign resources } \\
\text { (In percent of GNP) }\end{array}$ & $\begin{array}{r}1,649 \\
1,089 \\
15.6 \\
560 \\
8.0\end{array}$ & $\begin{array}{r}1,647 \\
1,566 \\
19.6 \\
81 \\
1.0\end{array}$ & $\begin{array}{r}1,685 \\
1,768 \\
20.2 \\
-83 \\
-1.0\end{array}$ & $\begin{array}{r}2,182 \\
1,867 \\
19.2 \\
315 \\
3.2\end{array}$ & $\begin{array}{r}2,896 \\
2,316 \\
20.7 \\
580 \\
5.2\end{array}$ & $\begin{array}{r}2,837 \\
2,301 \\
18.8 \\
535 \\
4.4\end{array}$ & $\begin{array}{r}3,807 \\
2,977 \\
21.0 \\
829 \\
5.9\end{array}$ \\
\hline
\end{tabular}

Source: Ministry of Planning and Regional Development.

IIncludes changes in stocks. 
Table A|5. Consolidated Financial Operations of the Central Government'

\begin{tabular}{|c|c|c|c|c|c|c|c|}
\hline & 1986 & 1987 & 1988 & 1989 & 1990 & $\left.199\right|^{2}$ & $1992^{3}$ \\
\hline & \multicolumn{7}{|c|}{ (In millions of dinars) } \\
\hline Total revenue and grants & $2,430.0$ & $2,548.7$ & $2,743.6$ & $3,071.1$ & $3,356.3$ & $3,523.9$ & $4,085.3$ \\
\hline Total revenue & $2,425.9$ & $2,532.7$ & $2,713.2$ & $2,927.9$ & $3,286.2$ & $3,491.4$ & $4,031.2$ \\
\hline Tax revenue & $1,877.7$ & $1,896.8$ & $2,002.9$ & $2,257.8$ & $2,551.4$ & $2,874.6$ & $3,294.0$ \\
\hline Taxes on foreign trade & 606.2 & 632.4 & 730.6 & 816.7 & 888.5 & 954.5 & $1,111.9$ \\
\hline Other taxes & $1,271.5$ & $1,264.4$ & $1,272.3$ & $1,441.1$ & $1,662.9$ & $1,920.1$ & $2,182.1$ \\
\hline Nontax revenue & 548.2 & 635.9 & 710.3 & 670.1 & 734.8 & 616.8 & 737.2 \\
\hline Petroleum sector & 312.7 & 352.3 & 388.3 & 393.9 & 392.9 & 254.4 & 296.0 \\
\hline Other nontax revenue & 235.5 & 283.6 & 322.0 & 276.2 & 341.9 & 362.4 & 441.2 \\
\hline Grants & 4.1 & 16.0 & 30.4 & 143.2 & 70.1 & 32.5 & 54.1 \\
\hline Total expenditure and net lending & $2,750.5$ & $2,878.5$ & $3,130.2$ & $3,482.8$ & $3,787.1$ & $4,178.7$ & $4,445.0$ \\
\hline Total expenditure & $2,584.9$ & $2,718.1$ & $3,057.9$ & $3,418.1$ & $3,743.3$ & $4,202.3$ & $4,381.3$ \\
\hline Current expenditure & $1,877.1$ & $2,084.4$ & $2,255.6$ & $2,693.3$ & $2,862.9$ & 3.176 .1 & $3,490.4$ \\
\hline Wages and salaries & 743.8 & 778.6 & 833.7 & 949.7 & $1,013.5$ & $1,158.1$ & $1,301.8$ \\
\hline Goods and services & 182.7 & 212.1 & 165.4 & 207.5 & 231.3 & 285.7 & 288.5 \\
\hline Interest payments & 223.6 & 245.1 & 278.1 & 316.7 & 341.3 & 416.1 & 435.4 \\
\hline Foreign debt & 174.0 & 187.0 & 213.9 & 239.1 & 249.0 & 258.0 & 247.3 \\
\hline Domestic debt & 49.6 & 58.1 & 64.2 & 77.6 & 92.3 & 158.1 & 188.1 \\
\hline $\begin{array}{l}\text { Subsidies and transfers } \\
\text { Of which: }\end{array}$ & & I, 464.7 \\
\hline Consumer subsidies & 213.0 & 183.2 & 231.0 & 346.3 & 300.0 & 272.0 & 255.0 \\
\hline Capital expenditure & 707.8 & 633.7 & 802.3 & 724.8 & 880.4 & $1,026.2$ & 890.9 \\
\hline Direct investment & 393.6 & 321.1 & 448.5 & 403.2 & 497.6 & 697.3 & 559.9 \\
\hline Capital transfers and equity & 314.2 & 312.6 & 353.8 & 321.6 & 382.8 & 328.9 & 331.0 \\
\hline Net lending & 165.6 & 160.4 & 72.3 & 64.7 & 43.8 & -23.6 & 63.7 \\
\hline Overall deficit & -320.5 & -329.8 & -386.6 & -411.7 & -430.8 & -654.8 & -359.7 \\
\hline Financing & 320.5 & -329.8 & 386.6 & 411.7 & 430.8 & 654.8 & 359.7 \\
\hline Foreign & 213.7 & 100.6 & 140.4 & 117.7 & 75.0 & 319.2 & 22.4 \\
\hline Drawings & 470.6 & 393.6 & 466.8 & 520.9 & 538.0 & 799.4 & 579.0 \\
\hline Budgetary & 230.6 & 185.6 & 263.8 & 310.9 & 283.4 & 374.9 & 319.2 \\
\hline Extrabudgetary & 240.0 & 208.0 & 203.0 & 210.0 & 254.6 & 424.5 & 259.8 \\
\hline Amortization & -256.9 & -293.0 & -326.4 & -403.2 & -463.0 & -480.2 & -556.6 \\
\hline Domestic & 106.8 & 229.2 & 246.2 & 294.0 & 355.8 & 335.6 & 337.3 \\
\hline Banks & 72.7 & 94.0 & -44.0 & 45.0 & 85.0 & 45.0 & -113.7 \\
\hline Other ${ }^{4}$ & 34.1 & 135.2 & 290.2 & 249.0 & 270.8 & 290.6 & 451.0 \\
\hline \multicolumn{8}{|l|}{ Memorandum items: } \\
\hline GDP & $7,021.0$ & $7,997.0$ & $8,685.0$ & $9,661.0$ & $10,990.0$ & $12,194.0$ & $13,928.0$ \\
\hline Overall deficit, excluding grants & -324.6 & -345.8 & -417.0 & -554.9 & -500.9 & -687.3 & -413.8 \\
\hline \multirow[t]{2}{*}{ Military expenditure } & $\ldots$ & 187.8 & 167.5 & 196.0 & 224.9 & 256.7 & 260.2 \\
\hline & \multicolumn{7}{|c|}{ (In percent of GDP) } \\
\hline Revenue and grants & 34.6 & 31.9 & 31.6 & 31.8 & 30.5 & 28.9 & 29.3 \\
\hline Tax revenue & 26.7 & 23.7 & 23.1 & 23.4 & 23.2 & 23.6 & 23.7 \\
\hline Grants & 0.1 & 0.2 & 0.3 & 1.4 & 0.6 & 0.2 & 0.4 \\
\hline Expenditure and net lending & 39.2 & 36.0 & 36.0 & 36.1 & 34.5 & 34.3 & 31.9 \\
\hline Deficit, including grants & -4.6 & -4.1 & -4.5 & -4.3 & -3.9 & -5.4 & -2.6 \\
\hline Deficit, excluding grants & -4.6 & -4.3 & -4.8 & -5.7 & -4.6 & -5.6 & -3.0 \\
\hline
\end{tabular}

Source: Ministry of Finance.

'Includes current and capital budgets, special funds, extrabudgetary operations financed abroad, net treasury operations, and social security funds. Data for and after 1988 are presented in a new classification consistent with the IMF's Government Finance Statistics format. This change in classification slightly affects gross levels of revenue and expenditure, but not the deficit.

2Revised data.

3 Provisional data.

IIncluding payment float, errors, and omissions. 
Table A16. Consolidated Revenue and Grants of the Central Government (In millions of dinars)

\begin{tabular}{|c|c|c|c|c|c|c|c|}
\hline & 1986 & 1987 & 1988 & 1989 & 1990 & 1991 & $1992^{1}$ \\
\hline Revenue & $2,425.9$ & $2,532.7$ & $2,713.2$ & $2,927.9$ & $3,286.2$ & $3,491.4$ & $4,031.2$ \\
\hline Tax revenue & $1,877.7$ & $1,896.8$ & $2,002.9$ & $2,257.8$ & $2,551.4$ & $2,874.6$ & $3,294.0$ \\
\hline Taxes on income and profits ${ }^{2}$ & 336.5 & 335.0 & 325.9 & 378.1 & 404.7 & 501.2 & 560.4 \\
\hline Of which: Petroleum sector ${ }^{3}$ & 74.2 & 52.2 & 55.5 & 56.9 & 50.3 & 82.2 & 74.7 \\
\hline Social security contributions & 245.3 & 220.9 & 227.7 & 325.3 & 391.9 & 426.3 & 502.3 \\
\hline Taxes on payroll & 32.3 & 44.1 & 27.6 & 31.3 & 39.4 & 33.9 & 38.1 \\
\hline Property taxes & 47.9 & 48.6 & 52.6 & 52.2 & 64.9 & 69.0 & 76.7 \\
\hline Taxes on goods and services & 560.4 & 572.5 & 585.1 & 607.0 & 715.4 & 834.9 & 944.2 \\
\hline Turnover taxes and $\mathrm{VAT}^{4}$ & 239.1 & 273.9 & 252.5 & 209.7 & 272.2 & 316.7 & 371.4 \\
\hline Excises & 226.4 & 226.0 & 256.2 & 291.0 & 327.3 & 402.1 & 445.2 \\
\hline Other & 94.9 & 72.6 & 76.4 & 106.3 & 115.9 & 116.1 & 127.6 \\
\hline Taxes on international trade & & & & & & & \\
\hline and transactions & 606.2 & 632.4 & 730.6 & 816.8 & 888.5 & 954.5 & $1,111.9$ \\
\hline Import taxes & 589.4 & 599.6 & 710.4 & 794.0 & 868.0 & 935.3 & $1,094.0$ \\
\hline Export taxes & 8.0 & 10.0 & 7.7 & 9.5 & 9.4 & 11.7 & 9.5 \\
\hline Other & 8.8 & 22.8 & 12.5 & 13.3 & 11.1 & 7.5 & 8.4 \\
\hline Other tax revenue & 49.1 & 43.3 & 53.4 & 47.1 & 46.6 & 54.8 & 60.4 \\
\hline Nontax revenue & 548.2 & 635.8 & 709.8 & 668.6 & 727.9 & 609.6 & 732.9 \\
\hline Petroleum sector & 312.8 & 352.3 & 388.3 & 393.9 & 392.9 & 254.4 & 296.3 \\
\hline Other nontax revenue & 235.4 & 283.5 & 321.5 & 274.7 & 335.0 & 355.2 & 436.6 \\
\hline Capital revenue & - & 0.1 & 0.5 & 1.5 & 6.9 & 7.3 & 4.3 \\
\hline Grants & 4.1 & 16.0 & 30.4 & 143.2 & 70.1 & 32.5 & 54.1 \\
\hline Total revenue and grants & $2,430.0$ & $2,548.7$ & $2,743.6$ & $3,071.1$ & $3,356.3$ & $3,523.9$ & $4,085.3$ \\
\hline
\end{tabular}

Source: Ministry of Finance.

I Provisional data.

${ }^{2}$ Effective for 1990 incomes and profits, new tax rates were applied to individuals and companies.

${ }^{3}$ Effective with the 1991 budget year, public sector petroleum companies are subject to the normal tax regime.

4 Effective July I, 1988, the VAT replaced turnover taxes.

Table A 17. Government Petroleum Revenues

(In millions of dinars)

\begin{tabular}{|c|c|c|c|c|c|c|c|c|}
\hline & & 1986 & 1987 & 1988 & 1989 & 1990 & 1991 & $1992^{\prime}$ \\
\hline \multirow[t]{2}{*}{ I. } & $\begin{array}{l}\text { Profits from petroleum exploitation } \\
\text { (Title I, Articles } 51.02 \text { and } 51.03 \text { ) }\end{array}$ & 312.8 & 352.3 & 388.3 & 393.9 & 392.9 & 254.4 & 296.3 \\
\hline & $\begin{array}{l}\text { Profits } \\
\text { Surtax }\end{array}$ & $\begin{array}{r}268.9 \\
43.9\end{array}$ & $\begin{array}{r}334.7 \\
17.6\end{array}$ & $\begin{array}{r}354.9 \\
33.4\end{array}$ & $\begin{array}{r}367.7 \\
26.2\end{array}$ & $\begin{array}{r}346.7 \\
46.2\end{array}$ & $\begin{array}{r}197.1 \\
57.3\end{array}$ & $\begin{array}{r}263.9 \\
32.4\end{array}$ \\
\hline 2. & $\begin{array}{l}\text { Excises on refined petroleum products } \\
\text { (Title I. Article 21.07) }\end{array}$ & 48.1 & 51.5 & 76.7 & 98.9 & 107.0 & 161.0 & 170.5 \\
\hline 3. & Direct taxation of petroleum companies & 74.2 & 52.2 & 55.5 & 56.9 & 50.3 & 82.3 & 74.7 \\
\hline 4. & Tax revenue earmarked to treasury funds & 59.3 & 50.7 & 27.6 & - & - & 一 & - \\
\hline \multirow[t]{2}{*}{5.} & $\begin{array}{l}\text { Revenue from property } \\
\text { Of which: Gas pipeline }\end{array}$ & $\begin{array}{l}34.3 \\
25.0\end{array}$ & $\begin{array}{l}40.5 \\
40.5\end{array}$ & $\begin{array}{l}35.2 \\
35.2\end{array}$ & $\begin{array}{l}38.0 \\
38.0\end{array}$ & $\begin{array}{l}42.5 \\
42.5\end{array}$ & $\begin{array}{l}60.9 \\
60.9\end{array}$ & $\begin{array}{l}55.9 \\
55.9\end{array}$ \\
\hline & Total & 528.7 & 547.2 & 583.3 & 587.7 & 592.7 & 558.6 & 597.4 \\
\hline
\end{tabular}

Source: Ministry of Finance.

'Provisional data. 
Table A18. Economic Classification of Consolidated Expenditure of the Central Government' (In millions of dinars)

\begin{tabular}{lrrrrrrr} 
& 1986 & 1987 & 1988 & 1989 & 1990 & 1991 & $1992^{2}$ \\
\hline Current expenditure & $1,877.1$ & $2,084.4$ & $2,255.6$ & $2,693.3$ & $2,862.9$ & $3,176.1$ & $3,490.4$ \\
Wages and salaries & 743.8 & 778.6 & 833.7 & 949.7 & $1,013.5$ & $1,158.1$ & $1,301.8$ \\
Goods and other services & 182.7 & 212.1 & 165.4 & 207.4 & 231.4 & 285.7 & 288.5 \\
Interest on public debt & 223.6 & 245.1 & 278.1 & 316.7 & 341.3 & 416.1 & 435.4 \\
Foreign debt & 174.0 & 187.0 & 213.9 & 239.1 & 249.0 & 258.0 & 247.3 \\
Domestic debt & 49.6 & 58.1 & 64.2 & 77.6 & 92.3 & 158.1 & 188.1 \\
Subsidies and other current transfers & 727.0 & 848.6 & 978.4 & $1,219.5$ & $1,276.7$ & $1,316.2$ & $1,464.7$ \\
$\quad$ Of which: & & & & & & & \\
$\quad$ Consumer subsidies & 213.0 & 183.2 & 231.0 & 346.3 & 300.0 & 272.0 & 255.0 \\
$\quad$ Transfers to public enterprises & 65.6 & 71.4 & 51.6 & 64.8 & $\ldots$ & $\ldots$ & $\ldots$ \\
$\quad$ Transfers to households & 291.0 & 307.3 & 375.8 & 454.0 & $\ldots$ & $\ldots$ & $\ldots$ \\
Capital expenditure & 707.8 & 633.7 & 802.3 & 724.8 & 880.4 & $1,026.2$ & 890.9 \\
Direct investment & 393.6 & 321.1 & 448.5 & 403.2 & 497.6 & 697.3 & 559.9 \\
Capital transfers and equity & 314.2 & 312.6 & 353.8 & 321.6 & 382.8 & 328.9 & 331.0 \\
$\quad$ To public enterprises & 180.9 & 151.9 & 113.1 & 115.2 & $\ldots$ & $\ldots$ & $\ldots$ \\
$\quad$ Other & 133.3 & 160.7 & 240.7 & 206.4 & $\ldots$. & $\ldots$. & $\ldots$ \\
Total expenditure & $2,584.9$ & $2,718.1$ & $3,057.9$ & 3.418 .1 & 3.743 .3 & 4.202 .3 & $4,381.3$ \\
\hline
\end{tabular}

Source: Ministry of Finance.

'Includes all expenditure in the treasury accounts, extrabudgetary operations financed by external assistance, and expenditure of the social security schemes.

2 Provisional data.

Table A19. Operations of the Subsidy Fund (In millions of dinars)

\begin{tabular}{|c|c|c|c|c|c|c|c|}
\hline & 1986 & 1987 & 1988 & 1989 & 1990 & 1991 & $1992^{\prime}$ \\
\hline Subsidies and other expenditures ${ }^{2}$ & 218.0 & 188.2 & 194.9 & 333.8 & 319.3 & 284.8 & 274.1 \\
\hline Fertilizer & 16.9 & 17.7 & 10.0 & 21.0 & 17.0 & 11.5 & 5.0 \\
\hline Sugar & 19.9 & 15.0 & 17.0 & 35.0 & 34.5 & 18.0 & 13.5 \\
\hline Cereals & 133.2 & 110.0 & 116.0 & 200.0 & 180.0 & 165.0 & 165.0 \\
\hline Vegetable oil & 24.3 & 20.0 & 25.0 & 25.0 & 35.0 & 43.0 & 40.0 \\
\hline Milk & 9.2 & 8.5 & 15.0 & 35.2 & 8.4 & 11.0 & 24.3 \\
\hline Reimbursement of treasury loans & 5.0 & 5.0 & 5.0 & 5.0 & 5.0 & 5.0 & 5.0 \\
\hline Miscellaneous expenditures & 9.5 & 12.0 & 6.9 & 12.6 & 39.4 & 31.3 & 21.3 \\
\hline Total resources & 210.0 & 188.8 & 194.9 & 334.2 & 319.3 & 287.2 & 276.0 \\
\hline Earmarked taxes $^{3}$ & 135.0 & - & - & 18.3 & - & - & \\
\hline Current budget transfers & 68.0 & 188.0 & 188.0 & 231.0 & 300.0 & 272.0 & 255.0 \\
\hline Borrowing from treasury and & & & & & & & \\
\hline transfers from treasury funds & 7.0 & - & 3.9 & 21.7 & 1.2 & - & - \\
\hline Grants & - & - & 一 & 61.5 & - & 一 & \\
\hline Revaluation profits on stocks & - & 0.8 & 2.9 & 1.0 & 0.8 & 0.6 & 1.3 \\
\hline Other & 一 & - & 一 & 0.7 & 17.3 & 14.6 & 19.7 \\
\hline Overall surplus or deficit (-) & -8.0 & 0.6 & - & 0.4 & - & 2.4 & 1.9 \\
\hline
\end{tabular}

Source: Ministry of Finance.

'Provisional data.

${ }^{2} \mathrm{On}$ an accrual basis, including the expenditures directly financed through treasury advances.

Includes net position of subsidy fund, with importers, producers, and intermediaries involved in transactions of subsidized commodities. 
Table A20. Monetary Survey

(In millions of dinars; end of period)

\begin{tabular}{|c|c|c|c|c|c|c|c|c|}
\hline & & & & & & & & \\
\hline & 1986 & 1987 & Old & New' & 1989 & 1990 & 1991 & 1992 \\
\hline $\begin{array}{l}\text { Foreign assets (net) } \\
\text { Foreign assets } \\
\text { Foreign liabilities }\end{array}$ & $\begin{array}{r}54 \\
361 \\
-307\end{array}$ & $\begin{array}{r}176 \\
650 \\
-474\end{array}$ & $\begin{array}{r}532 \\
1,106 \\
-574\end{array}$ & $\begin{array}{l}542 \\
\cdots \\
\cdots\end{array}$ & $\begin{array}{r}668 \\
1,254 \\
-586\end{array}$ & $\begin{array}{r}612 \\
1,138 \\
-526\end{array}$ & $\begin{array}{r}526 \\
1,193 \\
-667\end{array}$ & $\begin{array}{r}547 \\
1,382 \\
-835\end{array}$ \\
\hline $\begin{array}{l}\text { Domestic credit } \\
\text { Credit to Government (net) } \\
\text { Central Bank } \\
\text { Deposit money banks } \\
\text { Counterpart of CCP2 deposits } \\
\text { Credit to the economy } \\
\text { Central Bank } \\
\text { Deposit money banks }\end{array}$ & $\begin{array}{r}4,263 \\
628 \\
-25 \\
575 \\
77 \\
3,636 \\
169 \\
3,466\end{array}$ & $\begin{array}{r}4,600 \\
721 \\
-1 \\
631 \\
91 \\
3,879 \\
191 \\
3,687\end{array}$ & $\begin{array}{r}4,685 \\
677 \\
-70 \\
653 \\
95 \\
4,008 \\
13 \\
3,996\end{array}$ & $\begin{array}{r}5,188 \\
677 \\
-70 \\
652 \\
95 \\
4,512 \\
13 \\
4,499\end{array}$ & $\begin{array}{r}5,563 \\
722 \\
-85 \\
715 \\
92 \\
4,841 \\
31 \\
4,810\end{array}$ & $\begin{array}{r}6,143 \\
808 \\
-55 \\
762 \\
100 \\
5,335 \\
34 \\
5,301\end{array}$ & $\begin{array}{r}6,741 \\
853 \\
-68 \\
793 \\
128 \\
5,888 \\
41 \\
5,847\end{array}$ & $\begin{array}{r}7,539 \\
739 \\
47 \\
535 \\
157 \\
6,800 \\
39 \\
6,760\end{array}$ \\
\hline $\begin{array}{l}\text { Money plus quasi money (M2) } \\
\text { Money } \\
\text { Currency } \\
\text { Demand deposits } \\
\text { Financial institutions } \\
\text { Nonfinancial enterprises } \\
\text { and households }\end{array}$ & $\begin{array}{r}3,263 \\
2,058 \\
651 \\
1,407 \\
11\end{array}$ & $\begin{array}{r}3,711 \\
2,025 \\
705 \\
1,320 \\
4\end{array}$ & $\begin{array}{r}4,417 \\
2,456 \\
800 \\
1,656 \\
21\end{array}$ & $\begin{array}{r}4,422 \\
2,460 \\
800 \\
1,660 \\
\ldots\end{array}$ & $\begin{array}{r}4,910 \\
2,527 \\
875 \\
1,652 \\
37\end{array}$ & $\begin{array}{r}5,220 \\
2,649 \\
1,005 \\
1,644 \\
11\end{array}$ & $\begin{array}{r}5,507 \\
2,640 \\
1,104 \\
1,536 \\
12\end{array}$ & $\begin{array}{r}5,957 \\
2,835 \\
1,156 \\
1,679 \\
14\end{array}$ \\
\hline $\begin{array}{l}\text { Quasi money } \\
\text { Financial institutions } \\
\text { Nonfinancial enterprises } \\
\text { and households }\end{array}$ & $\begin{array}{r}1,205 \\
23\end{array}$ & $\begin{array}{r}1,686 \\
16\end{array}$ & $\begin{array}{r}1,960 \\
64\end{array}$ & $\begin{array}{r}1,962 \\
\ldots\end{array}$ & $\begin{array}{r}2,383 \\
73\end{array}$ & $\begin{array}{r}2,571 \\
108\end{array}$ & $\begin{array}{r}2,867 \\
100\end{array}$ & $\begin{array}{r}3.122 \\
97\end{array}$ \\
\hline Long-term deposits & 3 & 3 & 4 & 226 & 254 & 321 & 351 & 388 \\
\hline $\begin{array}{l}\text { Other items (net) } \\
\text { Special resources } \\
\text { Capital accounts } \\
\text { Other }\end{array}$ & $\begin{array}{r}1,051 \\
461 \\
571 \\
20\end{array}$ & $\begin{array}{r}1,062 \\
501 \\
612 \\
-51\end{array}$ & $\begin{array}{r}797 \\
542 \\
449 \\
-194\end{array}$ & $\begin{array}{r}1,082 \\
\ldots \\
\ldots \\
\ldots\end{array}$ & $\begin{array}{r}1,067 \\
664 \\
574 \\
-172\end{array}$ & $\begin{array}{r}1,214 \\
734 \\
640 \\
-160\end{array}$ & $\begin{array}{r}1,410 \\
806 \\
759 \\
-155\end{array}$ & $\begin{array}{r}1,741 \\
848 \\
939 \\
-46\end{array}$ \\
\hline
\end{tabular}

Sources: Central Bank of Tunisia.

'To reflect the merger in 1989 of a development bank and a deposit money bank as well as the transformation of a housing bank into a deposit money bank, data for 1988 were adjusted ex post.

2Postal Checking System. 
Table A2I. Assets and Liabilities of the Central Bank (In millions of dinars; end of period)

\begin{tabular}{lrrrrrrr} 
& 1986 & 1987 & 1988 & 1989 & 1990 & 1991 & 1992 \\
\hline Foreign assets & 177 & 366 & 754 & 844 & 633 & 679 & 877 \\
Claims on Government & 62 & 71 & 49 & 54 & 64 & 95 & 117 \\
Claims on development banks & 12 & 12 & 22 & 27 & 51 & 89 & 84 \\
Claims on deposit money banks & 971 & 832 & 799 & 946 & 855 & 1,037 & 986 \\
Claims on other private sector & 157 & 179 & - & - & - & - & - \\
Assets = liabilities & 1,380 & 1,460 & 1,623 & 1,870 & 1,603 & 1,900 & 2,064 \\
Reserve money & 747 & 806 & 1,118 & 1,361 & 1,145 & 1,264 & 1,355 \\
$\quad$ Currency outside banks & 651 & 705 & 800 & 875 & 1,005 & 1,104 & 1,156 \\
$\quad$ Currency with banks & 18 & 24 & 31 & 28 & 44 & 43 & 40 \\
Banks' deposits & 17 & 1 & 283 & 455 & 89 & 89 & 134 \\
Claims of development & & & & 3 & 2 & 6 & 27 \\
$\quad$ banks and other financial institutions & 58 & 75 & 3 & 24 \\
$\quad$ Deposits of nonfinancial entities & 4 & 2 & 2 & 1 & 2 & 2 & 2 \\
Foreign liabilities & 140 & 221 & 250 & 259 & 148 & 243 & 301 \\
Government deposits and currency holdings & 87 & 72 & 119 & 139 & 119 & 164 & 71 \\
Counterpart funds & 46 & 72 & 79 & 94 & 66 & 70 & 64 \\
Allocation of SDRs & 20 & 20 & 20 & 20 & 20 & 43 & 45 \\
Capital accounts & 250 & 245 & 38 & 44 & 49 & 49 & 54 \\
Other items (net) & 90 & 24 & - & -46 & 57 & 68 & 174 \\
\hline
\end{tabular}

Source: Central Bank of Tunisia. 
Table A22. Assets and Liabilities of Deposit Money Banks (In millions of dinars; end of period)

\begin{tabular}{|c|c|c|c|c|c|c|c|}
\hline & 1986 & 1987 & 1988 & 1989 & 1990 & 1991 & 1992 \\
\hline Reserves & 47 & 55 & 346 & 459 & 118 & 130 & 129 \\
\hline Currency & 18 & 24 & 31 & 28 & 44 & 43 & 40 \\
\hline At Central Bank & 28 & 31 & 316 & 431 & 74 & 88 & 89 \\
\hline Foreign assets & 184 & 284 & 353 & 411 & 505 & 514 & 505 \\
\hline Claims on Government & 575 & 631 & 653 & 715 & 762 & 793 & 535 \\
\hline Equipment bonds & 572 & 627 & 644 & 664 & 729 & 668 & 324 \\
\hline Treasury bills & $\ldots$ & $\ldots$ & $\ldots$ & 47 & 30 & 119 & 159 \\
\hline National loans & $\ldots$ & $\ldots$ & $\ldots$ & .. & $\ldots$ & ... & 49 \\
\hline Other & 3 & 4 & 8 & 3 & 4 & 6 & 4 \\
\hline Claims on the economy & 3,466 & 3,687 & 3,996 & 4,810 & 5,301 & 5,847 & 6,760 \\
\hline Credit financed by ordinary resources & 2,957 & 3,118 & 3,381 & 4,121 & 4,543 & 4,950 & 5,720 \\
\hline Credit financed by special resources & 411 & 436 & 472 & 547 & 618 & 698 & 784 \\
\hline Equity portfolio & 98 & 133 & 143 & 141 & 140 & 199 & 256 \\
\hline Assets = liabilities & 4,271 & 4,658 & 5,347 & 6,394 & 6,686 & 7,285 & 7,930 \\
\hline Demand deposits & 1,322 & 1,226 & 1,557 & 1,557 & 1,537 & 1,401 & 1,516 \\
\hline Development banks & 7 & 3 & 18 & 35 & 5 & 7 & 10 \\
\hline \multicolumn{8}{|l|}{ Nonfinancial enterprises and } \\
\hline households & 1,315 & 1,223 & 1,539 & 1,522 & 1,532 & 1,394 & 1,506 \\
\hline Quasi-money liabilities & 1,203 & 1,685 & 1,960 & 2,383 & 2,571 & 2,845 & 3,102 \\
\hline Development banks & 21 & 15 & 64 & 73 & 108 & 78 & 77 \\
\hline \multicolumn{8}{|l|}{ Nonfinancial enterprises and } \\
\hline households & I,182 & 1,670 & 1,896 & 2,310 & 2,463 & 2,767 & 3,024 \\
\hline Term deposits & 454 & 717 & 584 & 681 & 614 & 601 & 664 \\
\hline Certificates of deposit & $\cdots$ & $\ldots$ & 129 & 192 & 185 & 90 & 54 \\
\hline Special savings deposits & 688 & 864 & 1,080 & 1,301 & 1,512 & 1,766 & 2,041 \\
\hline Other savings deposits & 7 & 7 & 12 & 18 & 29 & 44 & 30 \\
\hline \multicolumn{8}{|l|}{ Deposits in foreign exchange or } \\
\hline Other & 32 & 83 & 91 & 119 & 124 & 266 & 236 \\
\hline Long-term monetary liabilities & 3 & 3 & 4 & 254 & 321 & 351 & 388 \\
\hline Foreign liabilities & 167 & 253 & 324 & 328 & 378 & 425 & 534 \\
\hline Special resources & 414 & 429 & 463 & 571 & 668 & 736 & 785 \\
\hline Long-term foreign borrowing & 190 & 191 & 187 & 201 & 253 & 329 & ... \\
\hline Counterpart funds & 10 & 14 & 17 & 3 & 3 & 3 & $\ldots$ \\
\hline Government lending funds & 214 & 223 & 259 & 367 & 412 & 405 & $\ldots$ \\
\hline Credit from Central Bank & 969 & 877 & 808 & 937 & 848 & 1,021 & 978 \\
\hline Capital accounts & 321 & 368 & 411 & 530 & 592 & 710 & 885 \\
\hline Other items (net) & -128 & -183 & -181 & -166 & -228 & -204 & -257 \\
\hline
\end{tabular}

Source: Central Bank of Tunisia. 
Table A23. Selected Interest Rates

(In percent; end of period)

\begin{tabular}{|c|c|c|c|c|c|c|c|c|c|c|}
\hline & \multirow[b]{2}{*}{1986} & \multirow[b]{2}{*}{1987} & \multirow[b]{2}{*}{1988} & \multirow[b]{2}{*}{1989} & \multirow[b]{2}{*}{1990} & \multirow[b]{2}{*}{1991} & \multicolumn{4}{|c|}{1992} \\
\hline & & & & & & & 1 & II & III & IV \\
\hline \multicolumn{11}{|l|}{ Central Bank } \\
\hline $\begin{array}{l}\text { Money market rate } \\
\text { Discount of preferential credits }\end{array}$ & 10.25 & 9.50 & 8.63 & 11.31 & 11.81 & 11.81 & 11.81 & 11.81 & 11.81 & 11.31 \\
\hline Export prefinancing & 4.00 & 4.00 & 4.00 & 4.00 & 6.25 & 6.25 & 7.25 & 7.25 & 8.25 & 8.25 \\
\hline Seasonal products & 4.50 & 4.75 & 4.75 & 4.75 & 5.75 & 5.75 & 6.75 & 6.75 & 7.75 & 7.75 \\
\hline Agricultural equipment & 5.50 & 6.00 & 6.00 & 6.00 & 6.50 & 6.50 & 7.50 & 7.50 & 8.50 & 8.50 \\
\hline PME' investments & 6.50 & 6.50 & 6.50 & 6.50 & 7.50 & 7.50 & 8.50 & 8.50 & 9.50 & 9.50 \\
\hline \multicolumn{11}{|l|}{ Commercial banks } \\
\hline Maximum lending/overdraft rate & 12.63 & 13.00 & 11.63 & 13.75 & 14.81 & 14.81 & $\ldots{ }^{2}$ & $\ldots{ }^{2}$ & $\ldots{ }^{2}$ & $\ldots{ }^{2}$ \\
\hline Special savings deposit rate & 8.15 & 7.50 & 6.63 & 9.25 & 9.63 & 9.63 & 9.63 & 9.63 & 9.63 & 9.63 \\
\hline
\end{tabular}


Table A24. Balance of Payments

(In millions of SDRs)

\begin{tabular}{|c|c|c|c|c|c|c|c|}
\hline & 1986 & 1987 & 1988 & 1989 & 1990 & 1991 & $\frac{1992}{\text { Prel. }}$ \\
\hline Current account & -602 & -76 & 72 & -259 & -487 & -423 & -666 \\
\hline $\begin{array}{l}\text { Trade balance } \\
\text { Exports, f.o.b. } \\
\text { Energy } \\
\text { Nonenergy } \\
\text { Imports, f.o.b. } \\
\text { Energy } \\
\text { Nonenergy }\end{array}$ & $\begin{array}{r}-833 \\
1,507 \\
365 \\
1,142 \\
-2,340 \\
-203 \\
-2,137\end{array}$ & $\begin{array}{r}-520 \\
1,653 \\
390 \\
1,262 \\
-2,172 \\
-246 \\
-1,926\end{array}$ & $\begin{array}{r}-816 \\
1,783 \\
287 \\
1,496 \\
-2,599 \\
-182 \\
-2,417\end{array}$ & $\begin{array}{r}-947 \\
2,286 \\
456 \\
1,830 \\
-3,234 \\
-297 \\
-2,937\end{array}$ & $\begin{array}{r}-1,260 \\
2,592 \\
448 \\
2,144 \\
-3,852 \\
-359 \\
-3,493\end{array}$ & $\begin{array}{r}-870 \\
2,711 \\
387 \\
2,324 \\
-3,581 \\
-289 \\
-3,292\end{array}$ & $\begin{array}{r}-1,446 \\
2,863 \\
432 \\
2,431 \\
-4,309 \\
-319 \\
-3,990\end{array}$ \\
\hline Total services & 231 & 443 & 888 & 689 & 773 & 447 & 780 \\
\hline $\begin{array}{l}\text { Nonfactor services (net) } \\
\text { Of which: Receipts from tourism } \\
\text { Transfers (net) }\end{array}$ & $\begin{array}{l}285 \\
414 \\
-54\end{array}$ & $\begin{array}{r}445 \\
531 \\
-2\end{array}$ & $\begin{array}{r}843 \\
942 \\
45\end{array}$ & $\begin{array}{r}635 \\
724 \\
54\end{array}$ & $\begin{array}{l}594 \\
695 \\
179\end{array}$ & $\begin{array}{r}404 \\
500 \\
43\end{array}$ & $\begin{array}{l}671 \\
749 \\
109\end{array}$ \\
\hline $\begin{array}{l}\text { Of which: } \\
\text { Workers' remittances } \\
\text { Interest on external debt }\end{array}$ & $\begin{array}{r}308 \\
-277\end{array}$ & $\begin{array}{r}376 \\
-290\end{array}$ & $\begin{array}{r}405 \\
-306\end{array}$ & $\begin{array}{r}381 \\
-322\end{array}$ & $\begin{array}{r}441 \\
-311\end{array}$ & $\begin{array}{r}417 \\
-294\end{array}$ & $\begin{array}{r}449 \\
-320\end{array}$ \\
\hline $\begin{array}{l}\text { Capital account } \\
\text { Grants } \\
\text { Direct and portfolio }\end{array}$ & $\begin{array}{r}407 \\
35\end{array}$ & $\begin{array}{r}186 \\
27\end{array}$ & $\begin{array}{r}223 \\
45\end{array}$ & $\begin{array}{r}320 \\
58\end{array}$ & $\begin{array}{r}412 \\
60\end{array}$ & $\begin{array}{r}375 \\
24\end{array}$ & $\begin{array}{r}749 \\
48\end{array}$ \\
\hline $\begin{array}{l}\text { investment (net) } \\
\text { Medium- and long-term loans } \\
\text { Disbursements } \\
\text { Amortization }\end{array}$ & $\begin{array}{r}132 \\
202 \\
669 \\
-467\end{array}$ & $\begin{array}{r}71 \\
24 \\
542 \\
-518\end{array}$ & $\begin{array}{r}82 \\
43 \\
545 \\
-502\end{array}$ & $\begin{array}{r}113 \\
110 \\
708 \\
-598\end{array}$ & $\begin{array}{r}137 \\
161 \\
781 \\
-620\end{array}$ & $\begin{array}{r}120 \\
181 \\
796 \\
-615\end{array}$ & $\begin{array}{r}321 \\
225 \\
854 \\
-629\end{array}$ \\
\hline Short-term capital and others & 39 & 65 & 53 & 40 & 56 & 51 & 155 \\
\hline Overall surplus or deficit (-) & -195 & 110 & 295 & 62 & -74 & -48 & 83 \\
\hline $\begin{array}{l}\text { Changes in net reserves } \\
\text { (increase -) } \\
\text { Use of IMF resources } \\
\text { Other assets, net (increase -) }\end{array}$ & $\begin{array}{r}195 \\
150 \\
45\end{array}$ & $\begin{array}{r}-110 \\
41 \\
-151\end{array}$ & $\begin{array}{r}-295 \\
15 \\
-310\end{array}$ & $\frac{-62}{-62}$ & $\begin{array}{r}74 \\
-82 \\
156\end{array}$ & $\begin{array}{l}48 \\
56 \\
-8\end{array}$ & $\begin{array}{r}-83 \\
31 \\
-114\end{array}$ \\
\hline Memorandum items: & & & & & & & \\
\hline $\begin{array}{l}\text { Current account deficit (-) } \\
\text { (in percent of GDP) } \\
\text { Gross reserves }\end{array}$ & -8.0 & -1.0 & 1.0 & -3.3 & -5.3 & -4.4 & -6.0 \\
\hline $\begin{array}{l}\text { (in months of imports) } \\
\text { Debt-service ratio' }\end{array}$ & $\begin{array}{r}1.3 \\
27.9\end{array}$ & $\begin{array}{r}2.1 \\
26.8\end{array}$ & $\begin{array}{r}3.1 \\
22.3\end{array}$ & $\begin{array}{r}2.7 \\
23.0\end{array}$ & $\begin{array}{r}1.8 \\
22.7\end{array}$ & $\begin{array}{r}1.9 \\
23.5\end{array}$ & $\begin{array}{r}1.8 \\
19.9\end{array}$ \\
\hline
\end{tabular}

Source: Ministry of Planning and Regional Development.

'As a percentage of exports of goods and services, including IMF charges. 
Table A25. Foreign Trade Indicators

(Changes in percent)

\begin{tabular}{|c|c|c|c|c|c|c|c|}
\hline & & & & & & & 1992 \\
\hline & 1986 & 1987 & 1988 & 1989 & 1990 & 1991 & Prel. \\
\hline \multicolumn{8}{|l|}{ Exports' } \\
\hline $\begin{array}{l}\text { Value (in dinars) } \\
\text { Volume } \\
\text { Price }\end{array}$ & $\begin{array}{r}-2.7 \\
11.3 \\
-12.6\end{array}$ & $\begin{array}{r}26.1 \\
8.9 \\
15.9\end{array}$ & $\begin{array}{r}16.1 \\
8.7 \\
6.8\end{array}$ & $\begin{array}{l}35.3 \\
18.8 \\
13.9\end{array}$ & $\begin{array}{r}11.0 \\
4.5 \\
6.3\end{array}$ & $\begin{array}{r}11.0 \\
4.7 \\
6.0\end{array}$ & $\begin{array}{r}4.0 \\
5.8 \\
-1.7\end{array}$ \\
\hline $\begin{array}{l}\text { Value (in SDRs) } \\
\text { Price }\end{array}$ & $\begin{array}{l}-11.5 \\
-20.5\end{array}$ & $\begin{array}{l}9.7 \\
0.7\end{array}$ & $\begin{array}{r}7.9 \\
-0.7\end{array}$ & $\begin{array}{r}28.2 \\
7.9\end{array}$ & $\begin{array}{r}13.4 \\
8.5\end{array}$ & $\begin{array}{r}4.6 \\
-0.1\end{array}$ & $\begin{array}{r}5.6 \\
-0.2\end{array}$ \\
\hline \multicolumn{8}{|l|}{ Imports 1.2} \\
\hline $\begin{array}{l}\text { Value (in dinars) } \\
\text { Volume } \\
\text { Price }\end{array}$ & $\begin{array}{r}0.7 \\
-0.4 \\
1.2\end{array}$ & $\begin{array}{r}8.9 \\
-3.4 \\
12.7\end{array}$ & $\begin{array}{r}26.2 \\
17.0 \\
7.9\end{array}$ & $\begin{array}{l}31.1 \\
16.4 \\
12.6\end{array}$ & $\begin{array}{r}16.9 \\
9.6 \\
6.7\end{array}$ & $\begin{array}{r}-1.3 \\
-7.9 \\
7.1\end{array}$ & $\begin{array}{r}18.5 \\
16.2 \\
2.0\end{array}$ \\
\hline $\begin{array}{l}\text { Value (in SDRs) } \\
\text { Price }\end{array}$ & $\begin{array}{l}-8.4 \\
-8.0\end{array}$ & $\begin{array}{l}-5.3 \\
-2.0\end{array}$ & $\begin{array}{r}17.3 \\
0.3\end{array}$ & $\begin{array}{r}24.2 \\
6.7\end{array}$ & $\begin{array}{r}19.4 \\
8.9\end{array}$ & $\begin{array}{r}-7.0 \\
0.9\end{array}$ & $\begin{array}{r}20.3 \\
3.6\end{array}$ \\
\hline Terms of trade & -13.6 & 2.8 & -1.0 & 1.1 & -0.4 & -1.0 & -3.6 \\
\hline
\end{tabular}

Source: Ministry of Planning and Regional Development.

'Current price data are based on customs trade statistics. Volume figures are constant price merchandise trade, consistent with the national accounts, with base year 1990. Conversion into SDRs was at (dinars/SDR); 1986 (0.931); 1987 (1.072); 1988 (1.153); 1989 (1.217); 1990 (1.192); 1991 (1.265); and 1992 (1.246).

${ }^{2}$ Imports are on a c.i.f. basis.

\section{Table A26. Value of Foreign Trade by Commodity Class'} (In millions of SDRs)

\begin{tabular}{|c|c|c|c|c|c|c|c|}
\hline & & & & & & & 1992 \\
\hline & 1986 & 1987 & 1988 & 1989 & 1990 & 1991 & Prel. \\
\hline Exports, f.o.b. & 1,507 & 1,653 & 1,783 & 2,286 & 2,592 & 2,711 & 2,863 \\
\hline $\begin{array}{l}\text { Energy products } \\
\text { Nonenergy }\end{array}$ & $\begin{array}{r}365 \\
1,142\end{array}$ & $\begin{array}{r}390 \\
1,263\end{array}$ & $\begin{array}{r}287 \\
1,496\end{array}$ & $\begin{array}{r}456 \\
1,830\end{array}$ & $\begin{array}{r}448 \\
2,144\end{array}$ & $\begin{array}{r}387 \\
2,324\end{array}$ & $\begin{array}{r}432 \\
2,431\end{array}$ \\
\hline Phosphates and derivatives & 326 & 307 & 396 & 447 & 381 & 389 & 395 \\
\hline Agriculture (including agro-processing) & 188 & 213 & 223 & 232 & 293 & 412 & 295 \\
\hline Textiles and leather & 455 & 515 & 575 & 719 & 993 & 1,050 & 1,244 \\
\hline Mechanical and electrical industry & 114 & $|3|$ & 167 & 191 & 299 & 320 & 341 \\
\hline Other goods & 60 & 95 & 135 & 241 & 179 & 154 & 156 \\
\hline Imports, c.i.f. & 2,473 & 2,342 & 2,747 & 3,411 & 4,072 & 3,786 & 4,555 \\
\hline Energy products & 215 & 246 & 181 & 296 & 359 & 289 & 319 \\
\hline Nonenergy & 2,258 & 2,096 & 2,565 & 3.115 & 3,713 & 3,497 & 4,236 \\
\hline Raw materials and semifinished goods & 878 & 851 & 1,000 & 1,136 & 1,272 & 1.185 & 1,477 \\
\hline Equipment & 542 & 402 & 459 & 652 & 910 & 953 & 1,106 \\
\hline Food & 308 & 242 & 412 & 451 & 373 & 246 & 305 \\
\hline Nonfood consumer goods & 530 & 601 & 696 & 876 & 1,157 & 1,113 & 1,348 \\
\hline Memorandum item: & & & & & & & \\
\hline Net energy exports & 150 & 144 & 106 & 160 & 89 & 98 & 113 \\
\hline
\end{tabular}

Source: Ministry of Planning and Regional Development.

'Based on customs statistics. 
Table A27. Volume of Foreign Trade by Commodity Class 1 (Growth rates in percent)

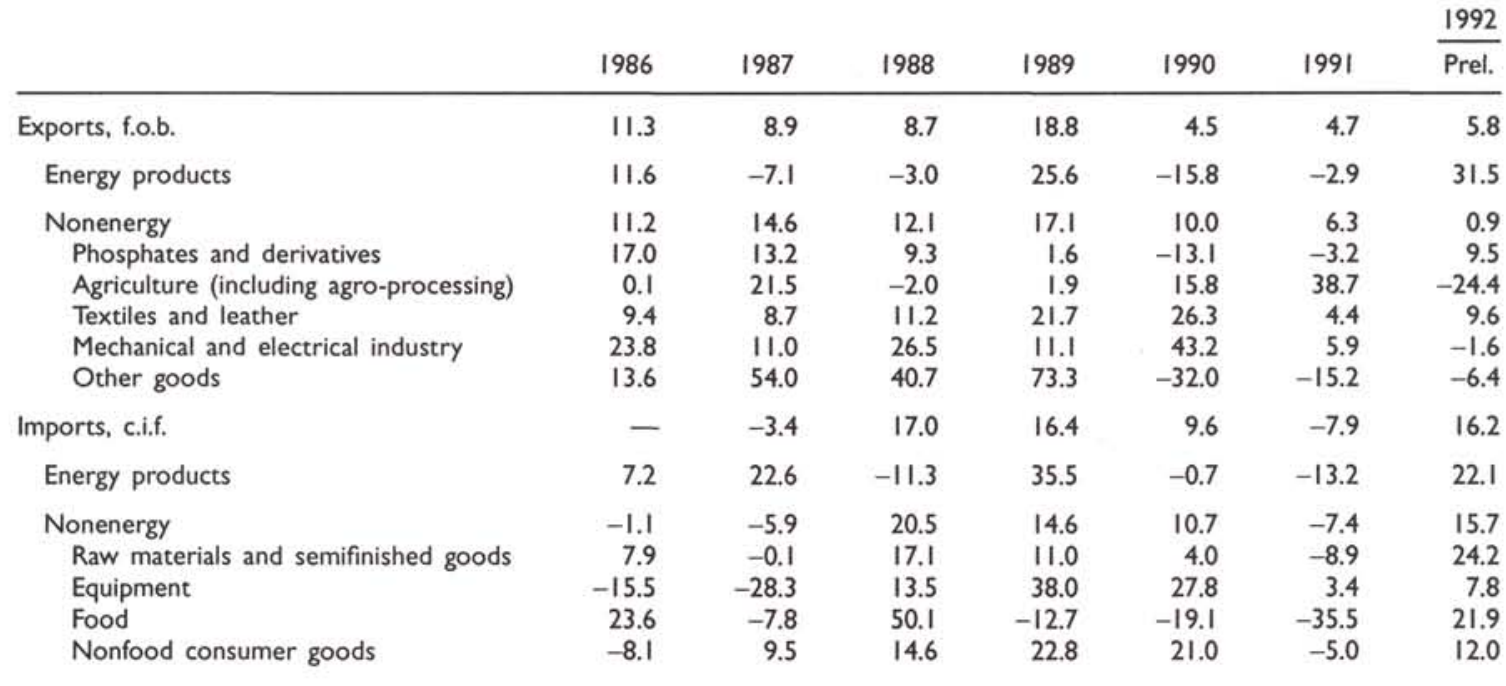

Source: Ministry of Planning and Regional Development.

'Based on customs statistics. 
Table A28. Trade Balance in Hydrocarbons

\begin{tabular}{|c|c|c|c|c|c|c|c|}
\hline & & & & & & & 1992 \\
\hline & 1986 & 1987 & 1988 & 1989 & 1990 & 1991 & Prel. \\
\hline & \multicolumn{7}{|c|}{ (In millions of dinars) } \\
\hline \multicolumn{8}{|l|}{ A. Crude oil } \\
\hline Exports, f.o.b. & 321 & 393 & 298 & 487 & 451 & 408 & 475 \\
\hline Imports, f.o.b. & -35 & -44 & - & -69 & -54 & -15 & -42 \\
\hline Balance & 286 & 349 & 298 & 418 & 397 & 393 & 433 \\
\hline \multicolumn{8}{|l|}{ B. Refined products } \\
\hline Exports, f.o.b. & 20 & 38 & 43 & 57 & 70 & 56 & 50 \\
\hline Imports, f.o.b. & -138 & -157 & -134 & -211 & -206 & -274 & -258 \\
\hline Balance & -118 & -119 & -91 & -154 & -136 & -218 & -208 \\
\hline \multicolumn{8}{|l|}{ C. Gas } \\
\hline Exports & - & - & - & - & - & - & 一 \\
\hline Imports & -24 & -62 & -49 & -81 & -82 & -65 & -85 \\
\hline Balance & -24 & -62 & -49 & -81 & -82 & -65 & -85 \\
\hline \multicolumn{8}{|c|}{ D. Total $(A+B+C)$} \\
\hline Exports, f.o.b. & 341 & 431 & 341 & 544 & 521 & 464 & 525 \\
\hline Imports, f.o.b. & -197 & -263 & -183 & -361 & -342 & -354 & -385 \\
\hline \multirow[t]{2}{*}{ Balance } & 144 & 168 & 158 & 183 & 179 & 110 & 140 \\
\hline & \multicolumn{7}{|c|}{ (In thousands of tons of oil equivalent) } \\
\hline \multicolumn{8}{|l|}{ A. Crude oil } \\
\hline Exports & 3,994 & 3,686 & 3,334 & 3,796 & 3,338 & 3,304 & 3,989 \\
\hline Imports & -413 & -422 & - & -621 & -419 & -118 & -341 \\
\hline Balance & 3,581 & 3,264 & 3,334 & 3,175 & 2,919 & 3,186 & 3,648 \\
\hline \multicolumn{8}{|l|}{ B. Refined products } \\
\hline Exports & 278 & 380 & 500 & 564 & 566 & 542 & 460 \\
\hline Imports & $-1,562$ & $-1,327$ & $-1,360$ & $-1,678$ & $-2,154$ & $-2,186$ & $-2,254$ \\
\hline Balance & $-1,284$ & -947 & -860 & $-1,114$ & $-1,588$ & $-1,644$ & $-1,794$ \\
\hline \multicolumn{8}{|l|}{ C. Gas } \\
\hline Exports & - & - & - & - & - & - & - \\
\hline Imports & -318 & -929 & -763 & $-1,070$ & $-1,014$ & -639 & $-1,402$ \\
\hline Balance & -318 & -929 & -763 & $-1,070$ & $-1,014$ & -639 & $-1,402$ \\
\hline \multicolumn{8}{|c|}{ D. Total $(A+B+C)$} \\
\hline Exports & 4,272 & 4,066 & 3,834 & 4,360 & 3,904 & 3,846 & 4,449 \\
\hline Imports & $-2,293$ & $-2,678$ & $-2,123$ & $-3,369$ & $-3,587$ & $-2,943$ & $-3,997$ \\
\hline Balance & 1,979 & 1,388 & 1,711 & 991 & 317 & 903 & 452 \\
\hline
\end{tabular}

Source: Ministry of Planning and Regional Development. 
Table A29. Exports of Phosphate Rock, Phosphate Derivatives, and Other Chemical Products (Volume in thousands of tons; value in millions of dinars)

\begin{tabular}{|c|c|c|c|c|c|c|c|c|c|c|c|c|c|c|}
\hline & \multicolumn{2}{|c|}{1986} & \multicolumn{2}{|c|}{1987} & \multicolumn{2}{|c|}{1988} & \multicolumn{2}{|c|}{1989} & \multicolumn{2}{|c|}{1990} & \multicolumn{2}{|c|}{$\begin{array}{c}1991 \\
\text { Preliminary }\end{array}$} & \multicolumn{2}{|c|}{$\begin{array}{c}1992 \\
\text { Preliminary }\end{array}$} \\
\hline & Volume & Value & Volume & Value & Volume & Value & Volume & Value & Volume & Value & Volume & Value & Volume & Value \\
\hline Phosphate rock & $1,205.8$ & 25.8 & $1,244.8$ & 23.4 & $1,155.5$ & 27.6 & $1,077.3$ & 30.7 & 592.8 & 15.5 & 425.9 & 11.3 & 956.1 & 22.4 \\
\hline Phosphoric acid & 252.0 & 74.7 & 317.3 & 69.7 & 513.6 & 146.5 & 425.8 & 149.3 & 420.5 & 119.6 & 542.5 & 164.3 & 542.9 & 139.2 \\
\hline Superphosphate & 716.1 & 76.7 & $1,000.6$ & 112.8 & 822.1 & 108.8 & 857.3 & 126.4 & 750.7 & 90.0 & 655.4 & 86.3 & 782.5 & 94.5 \\
\hline Ammonium phosphates & 488.1 & 75.2 & 489.6 & 74.3 & 470.9 & 85.3 & 604.7 & 118.0 & 502.9 & 80.5 & 511.3 & 93.5 & 657.4 & 95.6 \\
\hline Bicalcium phosphate & $\cdots$ & $\ldots$ & 40.7 & 5.5 & 41.2 & 6.6 & 47.1 & 9.1 & 46.7 & 8.1 & 53.1 & 9.5 & 53.9 & 9.2 \\
\hline Hyperphosphate & 34.3 & 4.6 & 39.9 & 2.3 & 34.7 & 2.1 & 24.7 & 1.6 & 40.8 & 2.7 & 35.9 & 2.4 & 31.8 & 2.2 \\
\hline
\end{tabular}

Source: Directorate General of Mines. 
Table A30. Exports and Imports of Primary Products by Major Category

(Volume in thousands of tons; value in millions of dinars)

\begin{tabular}{|c|c|c|c|c|c|c|c|c|c|c|c|c|c|c|}
\hline & \multicolumn{2}{|c|}{1986} & \multicolumn{2}{|c|}{1987} & \multicolumn{2}{|c|}{1988} & \multicolumn{2}{|c|}{1989} & \multicolumn{2}{|c|}{1990} & \multicolumn{2}{|c|}{$\begin{array}{c}1991 \\
\text { Preliminary }\end{array}$} & \multicolumn{2}{|c|}{$\begin{array}{c}1992 \\
\text { Preliminary }\end{array}$} \\
\hline & Volume & Value & Volume & Value & Volume & Value & Volume & Value & Volume & Value & Volume & Value & Volume & Value \\
\hline \multicolumn{15}{|l|}{ Exports } \\
\hline $\begin{array}{l}\text { Olive oil } \\
\text { Dates } \\
\text { Almonds } \\
\text { Citrus } \\
\text { Wine } \\
\text { Fish }\end{array}$ & $\begin{array}{r}44.2 \\
14.3 \\
3.4 \\
44.8 \\
36.4 \\
11.3\end{array}$ & $\begin{array}{r}53.4 \\
26.1 \\
8.7 \\
11.7 \\
5.3 \\
47.4 \\
47\end{array}$ & $\begin{array}{r}56.9 \\
15.8 \\
1.4 \\
51.9 \\
24.9 \\
13.7\end{array}$ & $\begin{array}{r}65.6 \\
31.7 \\
2.6 \\
17.8 \\
6.2 \\
63.0\end{array}$ & $\begin{array}{r}52.2 \\
15.8 \\
0.2 \\
43.2 \\
18.4 \\
17.3\end{array}$ & \begin{tabular}{r|}
70.7 \\
33.7 \\
0.5 \\
13.3 \\
6.6 \\
81.9
\end{tabular} & $\begin{array}{r}46.9 \\
16.6 \\
0.1 \\
40.5 \\
8.0 \\
14.4\end{array}$ & $\begin{array}{r}81.5 \\
37.8 \\
0.4 \\
13.4 \\
4.0 \\
84.4\end{array}$ & $\begin{array}{r}49.7 \\
18.0 \\
0.6 \\
29.3 \\
9.0 \\
17.4\end{array}$ & $\begin{array}{r}106.9 \\
44.9 \\
1.5 \\
9.8 \\
4.3 \\
101.1\end{array}$ & $\begin{array}{r}158.2 \\
19.5 \\
0.9 \\
25.6 \\
13.3 \\
13.6\end{array}$ & $\begin{array}{r}266.8 \\
48.8 \\
1.9 \\
10.5 \\
9.7 \\
79.5\end{array}$ & $\begin{array}{r}96.5 \\
17.1 \\
0.8 \\
20.4 \\
12.0 \\
12.0\end{array}$ & $\begin{array}{r}138.5 \\
43.6 \\
2.2 \\
8.1 \\
13.0 \\
69.2\end{array}$ \\
\hline \multicolumn{15}{|l|}{ Imports } \\
\hline $\begin{array}{l}\text { Soft wheat } \\
\text { Hard wheat } \\
\text { Barley } \\
\text { Maize } \\
\text { Sugar } \\
\text { Tea } \\
\text { Milk } \\
\text { Soybean oil } \\
\text { Meat (including } \\
\text { live animals } \\
\text { for slaughter) }\end{array}$ & $\begin{array}{r}681.4 \\
267.2 \\
117.1 \\
240.3 \\
183.4 \\
20.5 \\
24.8 \\
112.6\end{array}$ & $\begin{array}{r}62.8 \\
26.3 \\
7.4 \\
24.0 \\
26.2 \\
26.4 \\
23.6 \\
34.1\end{array}$ & $\begin{array}{r}577.1 \\
367.6 \\
24.2 \\
190.5 \\
183.2 \\
15.7 \\
24.1 \\
114.9\end{array}$ & $\begin{array}{r}46.0 \\
40.0 \\
1.5 \\
16.6 \\
28.5 \\
20.5 \\
22.9 \\
30.5\end{array}$ & $\begin{array}{r}736.5 \\
615.0 \\
519.3 \\
227.0 \\
170.0 \\
20.1 \\
31.0 \\
118.4\end{array}$ & $\begin{array}{l}87.0 \\
85.0 \\
54.0 \\
24.5 \\
34.5 \\
26.6 \\
33.0 \\
43.1\end{array}$ & $\begin{array}{r}611.3 \\
545.0 \\
176.6 \\
250.7 \\
176.4 \\
14.4 \\
28.7 \\
139.4\end{array}$ & $\begin{array}{r}104.9 \\
99.5 \\
24.4 \\
35.2 \\
47.0 \\
19.7 \\
46.2 \\
57.3\end{array}$ & $\begin{array}{r}714.1 \\
183.5 \\
127.7 \\
293.3 \\
207.9 \\
17.2 \\
30.4 \\
129.6\end{array}$ & $\begin{array}{l}94.1 \\
30.0 \\
16.8 \\
35.6 \\
70.9 \\
22.3 \\
42.5 \\
53.2\end{array}$ & $\begin{array}{r}558.9 \\
118.1 \\
4.4 \\
238.0 \\
168.0 \\
12.5 \\
17.1 \\
136.2\end{array}$ & $\begin{array}{r}48.3 \\
15.7 \\
0.6 \\
30.2 \\
44.7 \\
18.3 \\
21.3 \\
56.1\end{array}$ & $\begin{array}{r}596.2 \\
57.4 \\
4.8 \\
343.3 \\
234.5 \\
14.1 \\
27.6 \\
135.8\end{array}$ & $\begin{array}{r}72.0 \\
8.1 \\
0.7 \\
37.7 \\
58.5 \\
19.1 \\
41.3 \\
52.4\end{array}$ \\
\hline
\end{tabular}

(C)International Monetary Fund. Not for Redistribution 
Table A3I. Direction of Trade

(In percent)

\begin{tabular}{|c|c|c|c|c|c|c|c|c|}
\hline & & & & & & & & 1992 \\
\hline & & 1986 & 1987 & 1988 & 1989 & 1990 & 1991 & Prel. \\
\hline Exports, f.o.b. & & & & & & & & \\
\hline EC countries & & 73.3 & 78.6 & 74.4 & 73.7 & 77.8 & 76.1 & 77.4 \\
\hline Of which: $F$ & France & 23.4 & 21.8 & 25.8 & 24.6 & 26.6 & 25.2 & 26.9 \\
\hline & Italy & 13.8 & 16.8 & 18.9 & 18.9 & 21.2 & 19.5 & 16.9 \\
\hline & Germany & 15.3 & 19.7 & 14.1 & 12.6 & 15.1 & 16.4 & 16.9 \\
\hline & Netherlands & 3.9 & 3.2 & 2.9 & 2.5 & 2.5 & 2.7 & 2.6 \\
\hline & Belgium/Luxembourg & 5.6 & 6.5 & 6.2 & 6.4 & 7.0 & 6.2 & 6.9 \\
\hline & United Kingdom & 1.2 & 0.9 & 1.6 & 1.8 & 1.6 & 1.3 & 1.8 \\
\hline & Greece & 6.2 & 6.2 & 1.5 & 3.7 & 0.4 & 0.6 & 2.1 \\
\hline & Spain & 3.7 & 2.6 & 3.4 & 3.2 & 2.6 & 3.7 & 2.6 \\
\hline Oil exporting & countries & 9.3 & 6.2 & 7.4 & 11.2 & 10.4 & 11.2 & 8.6 \\
\hline Of which: L & Libya & 0.3 & 0.4 & 1.6 & 4.2 & 4.6 & 5.8 & 4.4 \\
\hline & Algeria & 5.2 & 3.1 & 2.5 & 2.2 & 2.3 & 2.1 & 2.4 \\
\hline & Iran & 0.8 & 0.7 & 0.3 & 1.3 & 0.8 & 0.5 & 0.7 \\
\hline Other countri & ries & 17.4 & 15.2 & 18.2 & 15.1 & 11.8 & 12.7 & 14.0 \\
\hline Of which: & United States & 0.7 & 1.6 & 1.0 & 2.3 & 0.9 & 0.7 & 0.8 \\
\hline & Turkey & 1.8 & 2.0 & 1.5 & 0.8 & 0.8 & 0.7 & 0.9 \\
\hline & Former U.S.S.R. & 1.4 & 1.7 & 1.1 & 0.8 & 1.3 & 1.1 & 0.3 \\
\hline & Japan & 0.1 & 0.1 & 0.2 & 0.2 & 0.3 & 0.3 & 0.3 \\
\hline & Switzerland & 0.4 & 0.2 & 0.4 & 0.3 & 0.4 & 0.5 & 0.3 \\
\hline Total & & 100.0 & 100.0 & 100.0 & 100.0 & 100.0 & 100.0 & 100.0 \\
\hline Imports, c.i.f. & & & & & & & & \\
\hline EC countries & & 68.4 & 67.0 & 66.8 & 66.9 & 70.2 & 71.6 & 71.1 \\
\hline Of which: $F$ & France & 27.9 & 27.3 & 24.8 & 26.4 & 27.9 & 26.0 & 25.8 \\
\hline & Italy & 10.7 & 11.3 & 13.3 & 13.7 & 15.9 & 17.4 & 18.2 \\
\hline & Germany & 13.0 & 12.6 & 12.6 & 11.7 & 12.5 & 14.2 & 14.0 \\
\hline & Netherlands & 2.5 & 2.3 & 2.4 & 2.4 & 2.6 & 2.2 & 2.2 \\
\hline & Belgium/Luxembourg & 5.3 & 4.5 & 4.8 & 4.7 & 4.8 & 5.4 & 4.7 \\
\hline & United Kingdom & 2.0 & 1.7 & 1.7 & 1.5 & 1.7 & 1.8 & 1.8 \\
\hline & Greece & 1.4 & 2.4 & 1.9 & 1.9 & 0.1 & 0.8 & 0.6 \\
\hline & Spain & 4.8 & 4.5 & 4.6 & 3.3 & 3.1 & 3.1 & 3.3 \\
\hline Other countri & ries & 31.6 & 33.0 & 33.2 & 33.1 & 29.8 & 28.4 & 28.9 \\
\hline Of which: $U$ & United States & 6.6 & 5.9 & 7.1 & 5.8 & 5.2 & 4.6 & 4.9 \\
\hline & Canada & 1.9 & 2.0 & 2.4 & 1.1 & 0.9 & 1.6 & 1.0 \\
\hline & Brazil & 0.4 & 0.5 & 0.7 & 0.3 & 0.5 & 0.4 & 0.6 \\
\hline & Argentina & 1.0 & 0.4 & 0.8 & 0.5 & 0.6 & 0.7 & 0.8 \\
\hline & Austria & 0.5 & 0.7 & 0.7 & 0.7 & 0.6 & 0.6 & 0.5 \\
\hline & Turkey & 0.5 & 0.5 & 1.9 & 1.5 & 0.9 & 1.1 & 0.9 \\
\hline & Sweden & 1.3 & 1.2 & 0.7 & 1.0 & 1.0 & 1.3 & 1.1 \\
\hline & Switzerland & 1.3 & 1.3 & 0.7 & 1.7 & 1.2 & 1.9 & 1.1 \\
\hline & Former U.S.S.R. & 1.3 & 0.9 & 1.1 & 0.8 & 1.7 & 1.4 & 1.3 \\
\hline & Former Yugoslavia & 0.3 & 0.6 & 0.5 & 0.4 & 0.7 & 0.4 & 0.5 \\
\hline & Romania & 0.5 & 0.6 & 0.2 & 0.7 & 0.1 & 0.2 & 0.1 \\
\hline & China & 1.2 & 0.7 & 0.9 & 0.4 & 0.6 & 0.7 & 0.8 \\
\hline & Japan & 1.6 & 0.9 & 1.4 & 1.4 & 1.8 & 2.3 & 2.3 \\
\hline & Saudi Arabia & 2.0 & 2.4 & 0.9 & 0.3 & 0.8 & 0.5 & 0.3 \\
\hline & Algeria & 2.5 & 1.8 & 2.4 & 2.4 & 2.0 & 1.2 & 1.5 \\
\hline Total & & 100.0 & 100.0 & 100.0 & 100.0 & 100.0 & 100.0 & 100.0 \\
\hline
\end{tabular}

Sources: Central Bank of Tunisia; and National Statistics Institute. 
Table A32. External Debt and Debt-Service Payments

\begin{tabular}{|c|c|c|c|c|c|c|c|}
\hline & & & & & & & 1992 \\
\hline & 1986 & 1987 & 1988 & 1989 & 1990 & $199 \mid$ & Prel. \\
\hline & \multicolumn{7}{|c|}{ (In millions of SDRs) } \\
\hline Disbursements & 669 & 542 & 545 & 708 & 781 & 796 & 854 \\
\hline Long-term capital & 311 & 355 & 399 & 485 & 478 & 542 & 482 \\
\hline Medium-term capital & 357 & 187 & 146 & 224 & 303 & 255 & 372 \\
\hline \multicolumn{8}{|l|}{ Debt-service payments } \\
\hline Medium- and long-term & 744 & 798 & 795 & 900 & 909 & 895 & 933 \\
\hline Interest & 276 & 280 & 293 & 302 & 289 & 280 & 305 \\
\hline Principal & 467 & 518 & 502 & 598 & 620 & 615 & 629 \\
\hline IMF & 1 & 10 & 13 & 20 & 104 & 113 & 36 \\
\hline Charges & 1 & 10 & 13 & 20 & 22 & 14 & 15 \\
\hline Repurchases & - & - & - & - & 82 & 99 & 21 \\
\hline Total debt service & 745 & 808 & 808 & 921 & 1,013 & 1,008 & 969 \\
\hline Interest & 277 & 290 & 306 & 322 & 311 & 294 & 320 \\
\hline Principal & 467 & 518 & 502 & 598 & 702 & 715 & 650 \\
\hline Debt outstanding & 4,305 & 4,267 & 4,336 & 4,713 & 5,007 & 5,355 & 5,478 \\
\hline Medium- and long-term & 4,139 & 4,051 & 4,115 & 4,500 & 4,881 & 5,175 & 5,256 \\
\hline Arab Monetary Fund & 16 & 26 & 16 & 7 & 3 & - & 11 \\
\hline \multirow[t]{2}{*}{ IMF credit } & 150 & 191 & 206 & 206 & 124 & 180 & 211 \\
\hline & \multicolumn{7}{|c|}{ (In percent of current receipts) } \\
\hline Total debt service' & 27.9 & 26.8 & 22.3 & 23.0 & 22.7 & 23.5 & 19.9 \\
\hline Interest & 10.4 & 9.6 & 8.4 & 8.1 & 7.0 & 6.9 & 6.6 \\
\hline Principal & 17.5 & 17.2 & 13.9 & 15.0 & 15.7 & 16.7 & 13.4 \\
\hline Excluding IMF & 27.9 & 26.4 & 22.0 & 22.5 & 20.4 & 20.9 & 19.2 \\
\hline Interest & 10.4 & 9.3 & 8.1 & 7.6 & 6.5 & 6.5 & 6.3 \\
\hline Principal & 17.5 & 17.2 & 13.9 & 15.0 & 13.9 & 14.4 & 12.9 \\
\hline
\end{tabular}

Source: Ministry of Planning and Regional Development.

IIncludes IMF charges and repurchases. 
Table A33. Composition of External Debt by Creditor (In millions of dinars; end of period)

\begin{tabular}{|c|c|c|c|c|c|c|c|}
\hline & 1986 & 1987 & 1988 & 1989 & 1990 & 1991 & $\frac{1992}{\text { Prel. }}$ \\
\hline $\begin{array}{l}\text { Multilateral organizations } \\
\text { Of which: World Bank } \\
\text { African Development Bank }\end{array}$ & $\begin{array}{r}743 \\
645 \\
64\end{array}$ & $\begin{array}{r}800 \\
682 \\
94\end{array}$ & $\begin{array}{l}998 \\
799 \\
147\end{array}$ & $\begin{array}{r}1,370 \\
987 \\
285\end{array}$ & $\begin{array}{r}1,610 \\
1,120 \\
395\end{array}$ & $\begin{array}{r}1,944 \\
1,230 \\
587\end{array}$ & $\begin{array}{r}2,036 \\
1,299 \\
675\end{array}$ \\
\hline $\begin{array}{l}\text { OECD countries } \\
\text { Of which: France } \\
\text { Germany } \\
\text { Japan } \\
\text { United States } \\
\text { Italy }\end{array}$ & $\begin{array}{r}2,494 \\
669 \\
510 \\
377 \\
368 \\
149\end{array}$ & $\begin{array}{r}2,748 \\
761 \\
541 \\
443 \\
325 \\
184\end{array}$ & $\begin{array}{r}3,034 \\
748 \\
570 \\
548 \\
349 \\
221\end{array}$ & $\begin{array}{r}3,064 \\
762 \\
611 \\
548 \\
382 \\
222\end{array}$ & $\begin{array}{r}3,363 \\
841 \\
639 \\
531 \\
426 \\
268\end{array}$ & $\begin{array}{r}3,662 \\
963 \\
667 \\
534 \\
505 \\
318\end{array}$ & $\begin{array}{r}3,895 \\
980 \\
690 \\
557 \\
517 \\
408\end{array}$ \\
\hline $\begin{array}{l}\text { Arab countries and organizations } \\
\text { Of which: Saudi Fund } \\
\text { Kuwaiti Fund } \\
\text { Arab Fund for Economic } \\
\text { and Social Development }\end{array}$ & $\begin{array}{r}421 \\
94 \\
128\end{array}$ & $\begin{array}{r}409 \\
94 \\
132\end{array}$ & $\begin{array}{l}400 \\
102 \\
123\end{array}$ & $\begin{array}{l}432 \\
121 \\
134\end{array}$ & $\begin{array}{l}467 \\
133 \\
145\end{array}$ & $\begin{array}{l}567 \\
134 \\
144\end{array}$ & $\begin{array}{l}651 \\
149 \\
131\end{array}$ \\
\hline Other countries & 96 & 87 & 109 & 87 & 100 & 88 & 99 \\
\hline Financial markets & 501 & 425 & 435 & 397 & 270 & 140 & 190 \\
\hline Total medium- and long-term debt & 4,254 & 4,470 & 4,975 & 5,350 & 5,810 & 6,400 & 6,870 \\
\hline $\begin{array}{l}\text { Arab Monetary Fund } \\
\text { IMF }\end{array}$ & $\begin{array}{r}16 \\
154\end{array}$ & $\begin{array}{r}28 \\
210\end{array}$ & $\begin{array}{r}19 \\
249\end{array}$ & $\begin{array}{r}8 \\
245\end{array}$ & $\begin{array}{r}3 \\
147\end{array}$ & $\overline{223}$ & $\begin{array}{r}14 \\
276\end{array}$ \\
\hline Total external debt & 4,424 & 4,709 & 5,243 & 5,603 & 5,960 & 6,622 & 7,160 \\
\hline (As percent of GDP) & 63.0 & 58.9 & 60.4 & 58.0 & 54.2 & 54.3 & 51.4 \\
\hline
\end{tabular}

Source: Ministry of Planning and Regional Development. 
Table A34. Selected Exchange Rate Indices'

(Period averoges; $1980=100$ )

\begin{tabular}{|c|c|c|c|c|c|c|}
\hline & \multirow[b]{2}{*}{$\begin{array}{l}\text { U.S. } \\
\text { dollar }\end{array}$} & \multirow[b]{2}{*}{$\begin{array}{l}\text { French } \\
\text { franc }\end{array}$} & \multirow[b]{2}{*}{ SDR } & \multicolumn{3}{|c|}{ Effective Exchange Rate ${ }^{2}$} \\
\hline & & & & Nominal & $\begin{array}{c}\text { Real } \\
\text { (CPI-based) }\end{array}$ & $\begin{array}{l}\text { Relative } \\
\text { prices }\end{array}$ \\
\hline $1986 \quad I$ & 55.2 & 94.1 & 63.8 & 88.2 & 90.6 & 102.6 \\
\hline II & 53.4 & 90.5 & 59.9 & 83.0 & 86.1 & 103.7 \\
\hline III & 49.6 & 79.7 & 53.7 & 73.1 & 75.7 & 103.6 \\
\hline IV & 46.7 & 72.7 & 50.4 & 67.2 & 71.1 & 105.7 \\
\hline Year & 51.0 & 83.6 & 56.6 & 77.9 & 80.9 & 103.9 \\
\hline $1987 \quad 1$ & 49.3 & 71.5 & 50.9 & 66.5 & 71.1 & 107.0 \\
\hline II & 48.8 & 69.5 & 49.0 & 64.6 & 69.4 & 107.5 \\
\hline III & 47.6 & 69.1 & 48.5 & 64.1 & 69.2 & 108.1 \\
\hline IV & 49.9 & 68.0 & 48.4 & 62.9 & 68.5 & 108.7 \\
\hline Year & 48.9 & 69.6 & 49.2 & 64.5 & 69.6 & 107.8 \\
\hline $1988 \quad 1$ & 50.0 & 67.1 & 47.6 & 62.2 & 67.9 & 109.1 \\
\hline II & 48.6 & 66.5 & 46.2 & 61.3 & 67.7 & 110.4 \\
\hline III & 45.0 & 67.2 & 45.1 & 61.5 & 68.4 & 111.2 \\
\hline IV & 45.6 & 65.4 & 44.2 & 59.7 & 67.0 & 112.3 \\
\hline Year & 47.2 & 66.5 & 45.7 & 61.2 & 67.7 & 110.8 \\
\hline $1989 \quad 1$ & 43.4 & 64.6 & 43.0 & 58.5 & 66.0 & 112.8 \\
\hline II & 42.0 & 65.1 & 43.1 & 59.0 & 66.8 & 113.1 \\
\hline III & 42.4 & 65.2 & 43.8 & 59.2 & 67.4 & 113.8 \\
\hline IV & 43.0 & 62.7 & 43.6 & 57.7 & 66.0 & 114.5 \\
\hline Year & 42.7 & 64.5 & 43.3 & 58.6 & 66.6 & 113.6 \\
\hline $1990 \quad 1$ & 44.7 & 60.7 & 44.2 & 56.8 & 65.2 & 114.8 \\
\hline II & 45.0 & 60.1 & 44.7 & 56.5 & 65.2 & 115.4 \\
\hline III & 46.4 & 58.6 & 44.0 & 55.3 & 64.1 & 115.9 \\
\hline IV & 48.5 & 58.1 & 44.1 & 55.1 & 64.5 & 117.0 \\
\hline Year & 46.1 & 59.4 & 44.2 & 55.9 & 64.8 & 115.8 \\
\hline 19911 & 47.4 & 58.4 & 43.6 & 55.0 & 65.3 & 118.7 \\
\hline II & 42.1 & 58.6 & 41.0 & 54.5 & 65.2 & 119.6 \\
\hline III & 42.0 & 58.9 & 40.9 & 54.8 & 65.9 & 120.2 \\
\hline IV & 44.1 & 57.9 & 41.4 & 54.2 & 65.3 & 120.3 \\
\hline Year & 43.8 & 58.5 & 41.7 & 54.6 & 65.4 & 119.7 \\
\hline $1992 \quad 1$ & 44.5 & 58.0 & 41.7 & 54.5 & 65.8 & 120.7 \\
\hline II & 44.9 & 57.8 & 42.0 & 54.7 & 66.5 & 121.5 \\
\hline III & 48.7 & 57.2 & 43.6 & 54.9 & 66.5 & 121.3 \\
\hline IV & 45.3 & 56.4 & 42.0 & 55.7 & 68.1 & 122.1 \\
\hline Year & 45.8 & 57.4 & 42.3 & 55.0 & 66.7 & 121.4 \\
\hline $1993 \quad 1$ & 41.1 & 53.9 & 38.9 & 54.0 & 65.7 & 121.8 \\
\hline
\end{tabular}

Sources: IMF, Data Fund, and Information Notice System.

'Foreign currency units per Tunisian dinar.

2 Weighted by non-oil trade and tourism flows of 16 partner and competitor countries. 
Table A35. Structure of Imports by Regime'

(Millions of dinars)

\begin{tabular}{lrrrrrrr} 
& 1986 & 1987 & 1988 & 1989 & 1990 & 1991 & $\frac{1992}{\text { Prel. }}$ \\
\hline Regime with restrictions & 1,465 & 1,269 & 1,098 & 1,152 & 1,133 & 1,074 & 534 \\
Import license & 955 & 792 & 771 & 878 & 951 & 954 & 446 \\
Annual import authorization & 510 & 477 & 327 & 274 & 182 & 120 & 88 \\
Regime without restrictions & 452 & 730 & 1,331 & 1,974 & 2,479 & 2,484 & 3,024 \\
Import certificate & 230 & 529 & 1,071 & 1,654 & 2,264 & 2,311 & 2,851 \\
$\quad$ Of which: Equipment goods & 31 & 21 & 77 & 150 & 146 & 166 & 166 \\
Temporary admission & 222 & 201 & 260 & 320 & 215 & 173 & 173 \\
$\quad$ Total' & 1,917 & 1,999 & 2,429 & 3,162 & 3,612 & 3,558 & 3,558 \\
\hline
\end{tabular}

Source: Central Bank of Tunisia.

I Total imports are less than those recorded in the balance of payments, primarily because imports without payments are not covered by the above regimes. 


\section{Appendix II Summary of the Tax System as of April 30,1993}

Tax

Nature of Tax

Levied on all resident corporations, cooperatives, and nonfinancial public enterprises, as well as on Tunisian-source profits of nonresident companies.

Losses can be carried forward as a deduction against profits of the following three years.

Provisional advance payments are required on current year's profits, in three installments, each being equal to 30 percent of the previous year's income tax in the sixth, ninth, and twelfth months of their taxable year. Adjustment is made upon submission of the tax return for the taxable year.

1.2 Individuals ${ }^{1}$
Levied on worldwide income of individuals domiciled in Tunisia.

Types of income include wages and salaries; professional income; business profits; profit shares; capital income; and royalty income.

Nonresidents are also subject to this tax on their Tunisiansource income. Tax is collected through withholding on wages and salaries, interest payments, dividends, director fees, and payments to nonresidents.

Advance payment is also required for business and professional income as in the case of corporations (see 1.1 above).

Lump-sum tax liability is established for enterprises with annual turnovers not exceeding the amounts specified in the tax code.

All private sector employers must join the National Social Security Fund, which pays pensions, family allowances, and other social security benefits.

Exemptions and Deductions

Exemptions: nonprofit professional associations with revenue from tax or quasi-tax sources; mutual funds; savings and assistance funds managed by nonpaid officials; nonprofit public entities; service cooperatives in agricultural and fishing activities; employee-owned production cooperatives.

Deductions: linear or degressive depreciations are allowed for business fixed assets; deduction allowed for charitable donations up to 2 percent of the turnover and for representation expenses up to 1 percent of the turnover; 50 percent of the construction cost of housing built for employees is deductible over a period of ten years.

Exemptions: remunerations of foreign diplomats (exempted on a reciprocal basis); life annuities paid to work-related accident victims; indemnities paid to victims of physical attacks by virtue of a court verdict; social security and welfare payments; special allowances to cover workrelated expenses; dividends paid by entities subject to the corporate tax; interest income from deposits at the National Savings Fund of Tunisia; interest from bank deposits in foreign currency or convertible dinars; and interest from savings deposits for housing.

Deductions: same as in the case of corporate profits (see 1.1 above).

Exemptions: none. Deductions: none.
Normal rate: 35 percent.

Reduced rate: 10 percent. The latter is applicable to profits of the following companies: enterprises in handicraft, agricultural, and fishing activities; service and consumption cooperatives; profits from youth employment programs or promotion funds for handicrafts and small traders.

Minimum tax: 0.5 percent of the turnover of the taxable year, with a ceiling of D 500 for companies subject to 10 percent rate and D 1,000 for companies subject to 35 percent rate. Tax withholding at source is applied to wages, salaries, and interest.

\begin{tabular}{lrc} 
Brackets & Rates \\
\hline & \multicolumn{3}{c}{ (In percent) } \\
First D & 1,500 & zero \\
Next D & 3,500 & 15 \\
Next D & 5,000 & 20 \\
Next D & 10,000 & 25 \\
Next D & 30,000 & 30 \\
Over D & 50,000 & 35
\end{tabular}

Minimum tax: 0.5 percent of the turnover of the taxable year with a ceiling of D 500 .
Social security

Employer: 15 percent.

Employees: 6 percent.

Retirement

Employers: 2.5 percent. Employees: 1.25 percent. 


\section{Tax}

Exemptions and Deductions

Rates
3. Taxes on payroll and work force

3.1 Vocational training tax

3.2 Contribution to the "Housing Promotion Fund for Wage Earners" (FoProlos)

4. Taxes on property

4.3 Transfer duties on property transfers
Levied on wages and salaries. None.

Levied on wages and salaries. None.

For inheritance, there is an allowance of D 2,000 for spouse, child, and other dependants, with a total ceiling of D 12,000 per estate. gift, or inheritance.
5. Taxes on goods and services

\subsection{Value-added tax} June 2, $1988^{2}$

5.2 Consumption duties (Law No. 88-62 of June 2, 1988, revised by the Finance Act of 1991)

5.3 Tax on insurance contracts

5.4 Motor vehicle tax
Levied on services, imports and wholesale trade, and production activities. Credit is given for the tax paid in previous stages for the same good. Lump-sum tax liability is applied for enterprises with annual turnovers not exceeding the amounts specified in the tax code.

Levied on selected goods.

Levied on premiums collected for insurance contracts.

Reinsurance.

Accident insurance for maids and similar employees working for private services. Risk insurance for export goods and export credit insurance.

Exemptions: exports as well as selected domestic and import goods, such as books, newspapers, periodicals, milk, and olive oil production.

None.

Annual levy on motorcycles and cars.
Normal rate: 2 percent. Reduced rate: 1 percent (for industrial manufacturing jobs).

1 percent.
Gifts: rates vary between 11.5 percent and 65 percent depending on relationship. Inheritance: progressive rates from 6 percent to 25 percent apply for close relatives and from 35 percent to 85 percent for distant relatives.

Other transfers are subject to rates between 0.7 percent and 18.8 percent.

Normal rate: 17 percent. Reduced rate: 6 percent for services, gas, electricity, fertilizers, handicrafts, etc.

High rate: 29 percent on luxury goods.

Ad valorem rates vary from 11 percent to 507 percent (champagne).

Specific rates (petroleum products).

Life insurance: $\quad 3$ percent Sea and air transport

insurance:

Fire insurance:

Agriculture: percent Business, industry, and tourism: 12 percent Other risks: Other insurance premiums:

24 percent

Motorcycles: from D 30 to

10 percent D 450 depending on the engine size;

Cars: from D 45 to D 1,500 depending on their taxable horsepower. 
6. Taxes on international trade

6.1 Taxes on imports 6.1.1 Customs duty

\subsubsection{Compensatory duty on imports}

\subsubsection{Temporary surcharge}

6.1.4 Service fee on imports

6.2 Export duties

\subsubsection{Service fee on} exports

\section{Other taxes}

7.3.2 Stamp duties
A three-column tariff system based on the Customs Cooperation Council Nomenclature with minimum, preferential, and general rates. Preferential treatment is given to goods from 15 countries of North Africa and the Middle East, provided they satisfy origin criteria. General treatment is given to goods from countries that do not have special commercial relationships with Tunisia, or do not apply the most-favored-nation clause.

Additional temporary import duty levied on limited range of finished and semifinished goods produced locally for which imports are liberalized. Introduced in 1991 during the Middle East crisis as a surcharge on import duties and taxes.

Flat fiscal duty on imports, regardless of origin.

Flat fiscal duty on selected exports.

Exemptions: numerous. categories of import ports such as: March 1990); mission, industrial warehousing); purposes; and rary tax relief.

Exemptions: numerous.
Rates: from 10 percent to 43 percent.

- enterprises approved under the Investment Incentive Laws (Law No. 87-51 of August 1987; Law No. 88110 of August 1988; Law No. 89-100 of November 1989; and Law No. 90-21 of

- goods used in manufacture under special customs regimes (e.g., temporary ad-

- goods used by particular institutions and bodies; military forces, diplomatic personnel, international organizations, and airlines;

- goods used for educational, cultural, social, and health

- household effects and travel goods within specified limits.

Exemptions or deductions may also be applied to certain categories of foodstuffs imported under special tempo-

Specific duties on a wide range of civil, administrative, and judicial procedures.
All duties are assessed ad valorem on c.i.f. value.

Rates: from 10 percent to 30 percent. To be eliminated gradually over three years from the date of introduction.

Rate: 5 percent of the import duties and taxes paid.

1.5 percent of the total of import duties, including VAT, excises, and temporary surcharge. The Budget Law provides a list of taxable imports.

1.5 percent of the export value (f.o.b.). Budget Law of 1988 provides a list of taxable exports.

Various rates up to D 10 , and D 100 in respect of company registration.

Sources: Individual and Company Income Tax Code; Value-Added Tax Code; and Customs Code.

${ }^{1}$ Applicable to 1990 income and profits.

${ }^{2}$ Effective July $1,1988$. 


\section{References}

International Monetary Fund, Exchange Arrangements and Exchange Restrictions Annual Report 1993 (Washington, 1993).

Tunisia, Central Bank of Tunisia. Rapport Annuel, various issues (Tunis).

Central Bank of Tunisia. Statistiques Financières, various issues (Tunis).

, Ministry of Finance. Loi des Finances, various issues (Tunis).

Ministry of Finance. Les Finances Publiques, various issues (Tunis).
Ministry of Planning and Regional Development. VIème Plan de Développement Economique et Social, 1982-86 (Tunis).

Ministry of Planning and Regional Development. VIIème Plan de Développement Economique et Social, 1987-91 (Tunis).

Ministry of Planning and Regional Development. VIIlème Plan de Développement, 1992-96 (Tunis).

Ministry of Planning and Regional Development. Budget Economique, various issues (Tunis). 


\section{Recent Occasional Papers of the International Monetary Fund}

109. The Path to Convertibility and Growth: The Tunisian Experience, by Saleh M. Nsouli, Sena Eken, Paul Duran, Gerwin Bell, and Zühtü Yücelik. 1993.

108. Recent Experiences with Surges in Capital Inflows, by Susan Schadler, Maria Carkovic, Adam Bennett, and Robert Kahn. 1993.

107. China at the Threshold of a Market Economy, by Michael W. Bell, Hoe Ee Khor, and Kalpana Kochhar with Jun Ma, Simon N'guiamba, and Rajiv Lall. 1993.

106. Economic Adjustment in Low-Income Countries: Experience Under the Enhanced Structural Adjustment Facility, by Susan Schadler, Franek Rozwadowski, Siddharth Tiwari, and David O. Robinson. 1993.

105. The Structure and Operation of the World Gold Market, by Gary O'Callaghan. 1993.

104. Price Liberalization in Russia: Behavior of Prices, Household Incomes, and Consumption During the First Year, by Vincent Koen and Steven Phillips. 1993.

103. Liberalization of the Capital Account: Experiences and Issues, by Donald J. Mathieson and Liliana Rojas-Suárez. 1993.

102. Financial Sector Reforms and Exchange Arrangements in Eastern Europe. Part I: Financial Markets and Intermediation, by Guillermo A. Calvo and Manmohan S. Kumar. Part II: Exchange Arrangements of Previously Centrally Planned Economies, by Eduardo Borensztein and Paul R. Masson. 1993.

101. Spain: Converging with the European Community, by Michel Galy, Gonzalo Pastor, and Thierry Pujol. 1993.

100. The Gambia: Economic Adjustment in a Small Open Economy, by Michael T. Hadjimichael, Thomas Rumbaugh, and Eric Verreydt. 1992.

99. Mexico: The Strategy to Achieve Sustained Economic Growth, edited by Claudio Loser and Eliot Kalter. 1992.

98. Albania: From Isolation Toward Reform, by Mario I. Blejer, Mauro Mecagni, Ratna Sahay, Richard Hides, Barry Johnston, Piroska Nagy, and Roy Pepper. 1992.

97. Rules and Discretion in International Economic Policy, by Manuel Guitián. 1992.

96. Policy Issues in the Evolving International Monetary System, by Morris Goldstein, Peter Isard, Paul R. Masson, and Mark P. Taylor. 1992.

95. The Fiscal Dimensions of Adjustment in Low-Income Countries, by Karim Nashashibi, Sanjeev Gupta, Claire Liuksila, Henri Lorie, and Walter Mahler. 1992.

94. Tax Harmonization in the European Community: Policy Issues and Analysis, edited by George Kopits. 1992.

93. Regional Trade Arrangements, by Augusto de la Torre and Margaret R. Kelly. 1992.

92. Stabilization and Structural Reform in the Czech and Slovak Federal Republic: First Stage, by Bijan B. Aghevli, Eduardo Borensztein, and Tessa van der Willigen. 1992.

91. Economic Policies for a New South Africa, edited by Desmond Lachman and Kenneth Bercuson with a staff team comprising Daudi Ballali, Robert Corker, Charalambos Christofides, and James Wein. 1992.

90. The Internationalization of Currencies: An Appraisal of the Japanese Yen, by George S. Tavlas and Yuzuru Ozeki. 1992.

89. The Romanian Economic Reform Program, by Dimitri G. Demekas and Mohsin S. Khan. 1991.

88. Value-Added Tax: Administrative and Policy Issues, edited by Alan A. Tait. 1991.

87. Financial Assistance from Arab Countries and Arab Regional Institutions, by Pierre van den Boogaerde. 1991.

86. Ghana: Adjustment and Growth, 1983-91, by Ishan Kapur, Michael T. Hadjimichael, Paul Hilbers, Jerald Schiff, and Philippe Szymczak. 1991. 
85. Thailand: Adjusting to Success-Current Policy Issues, by David Robinson, Yangho Byeon, and Ranjit Teja with Wanda Tseng. 1991.

84. Financial Liberalization, Money Demand, and Monetary Policy in Asian Countries, by Wanda Tseng and Robert Corker. 1991.

83. Economic Reform in Hungary Since 1968, by Anthony R. Boote and Janos Somogyi. 1991.

82. Characteristics of a Successful Exchange Rate System, by Jacob A. Frenkel, Morris Goldstein, and Paul R. Masson. 1991.

81. Currency Convertibility and the Transformation of Centrally Planned Economies, by Joshua E. Greene and Peter Isard. 1991.

80. Domestic Public Debt of Externally Indebted Countries, by Pablo E. Guidotti and Manmohan S. Kumar. 1991.

79. The Mongolian People's Republic: Toward a Market Economy, by Elizabeth Milne, John Leimone, Franek Rozwadowski, and Padej Sukachevin. 1991.

78. Exchange Rate Policy in Developing Countries: Some Analytical Issues, by Bijan B. Aghevli, Mohsin S. Khan, and Peter J. Montiel. 1991.

77. Determinants and Systemic Consequences of International Capital Flows, by Morris Goldstein, Donald J. Mathieson, David Folkerts-Landau, Timothy Lane, J. Saúl Lizondo, and Liliana RojasSuárez. 1991.

76. China: Economic Reform and Macroeconomic Management, by Mario Blejer, David Burton, Steven Dunaway, and Gyorgy Szapary. 1991.

75. German Unification: Economic Issues, edited by Leslie Lipschitz and Donogh McDonald. 1990.

74. The Impact of the European Community's Internal Market on the EFTA, by Richard K. Abrams, Peter K. Cornelius, Per L. Hedfors, and Gunnar Tersman. 1990.

73. The European Monetary System: Developments and Perspectives, by Horst Ungerer, Jouko J. Hauvonen, Augusto Lopez-Claros, and Thomas Mayer. 1990.

72. The Czech and Slovak Federal Republic: An Economy in Transition, by Jim Prust and an IMF Staff Team. 1990.

71. MULTIMOD Mark II: A Revised and Extended Model, by Paul Masson, Steven Symansky, and Guy Meredith. 1990.

70. The Conduct of Monetary Policy in the Major Industrial Countries: Instruments and Operating Procedures, by Dallas S. Batten, Michael P. Blackwell, In-Su Kim, Simon E. Nocera, and Yuzuru Ozeki. 1990.

69. International Comparisons of Government Expenditure Revisited: The Developing Countries, 1975-86, by Peter S. Heller and Jack Diamond. 1990.

68. Debt Reduction and Economic Activity, by Michael P. Dooley, David Folkerts-Landau, Richard D. Haas, Steven A. Symansky, and Ralph W. Tryon. 1990.

67. The Role of National Saving in the World Economy: Recent Trends and Prospects, by Bijan B. Aghevli, James M. Boughton, Peter J. Montiel, Delano Villanueva, and Geoffrey Woglom. 1990.

66. The European Monetary System in the Context of the Integration of European Financial Markets, by David Folkerts-Landau and Donald J. Mathieson. 1989.

65. Managing Financial Risks in Indebted Developing Countries, by Donald J. Mathieson, David FolkertsLandau, Timothy Lane, and Iqbal Zaidi. 1989.

64. The Federal Republic of Germany: Adjustment in a Surplus Country, by Leslie Lipschitz, Jeroen Kremers, Thomas Mayer, and Donogh McDonald. 1989.

63. Issues and Developments in International Trade Policy, by Margaret Kelly, Naheed Kirmani, Miranda Xafa, Clemens Boonekamp, and Peter Winglee. 1988.

Note: For information on the title and availability of Occasional Papers not listed, please consult the IMF Publications Catalog or contact IMF Publication Services. 